\title{
المقدهة
}

الحمد لله ذي القدرة والجلال، والعظمة والكمال، أحمده سبحانه

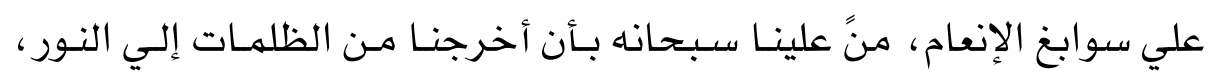

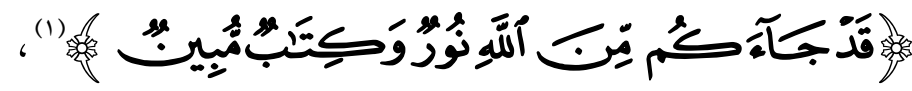

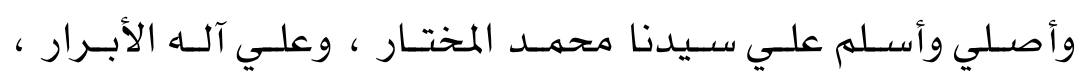

$$
\text { وصحابته الأخيار }
$$

\section{أوها بهد}

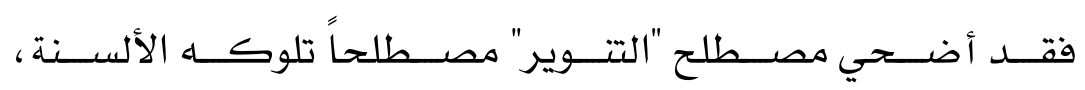

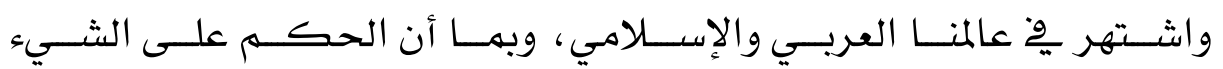

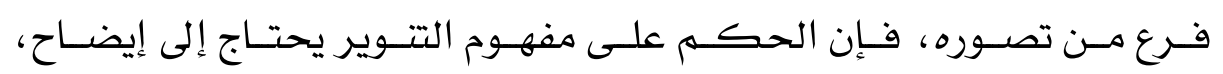
كي لا يحدث تخبطاً ِِّ أذهان الناس وينخد الحعوا به.

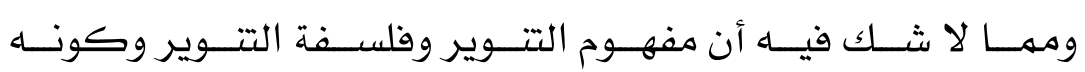

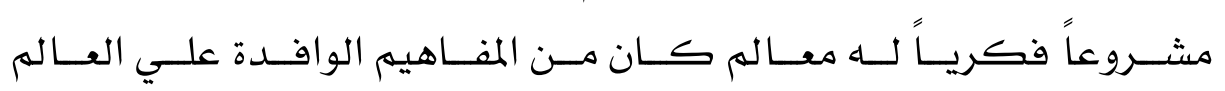

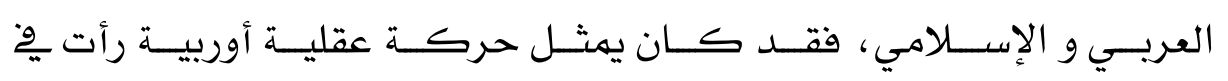

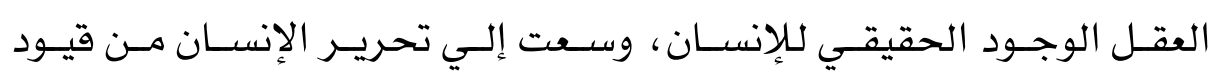

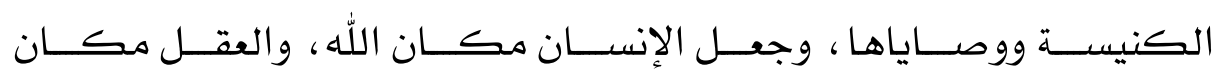

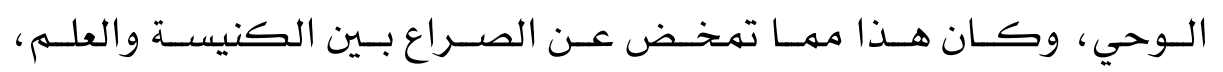

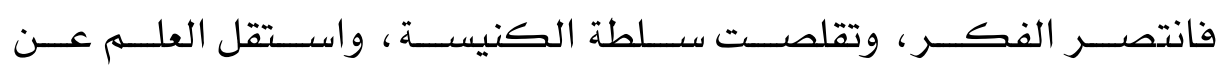




\section{التنوير الغريهي وإلتنويجي الإسلامي دراستيمقارئي}

الــدين، إذ العقـل والعلـم كانـا يتصــادمان مـع نصـوص الكتــاب المقـدس

$$
\text { - محرف - متعاليه الكنيسة. }
$$

إذاً هو تيار فكري لله ظروف لنشـأته ومضمونه.

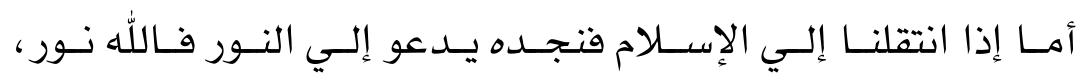

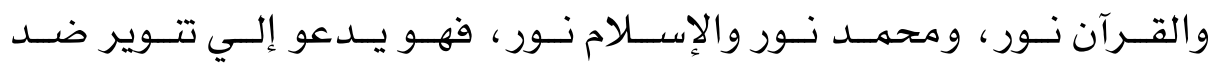

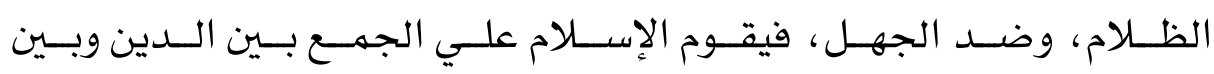

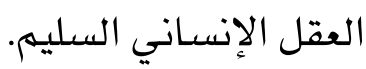

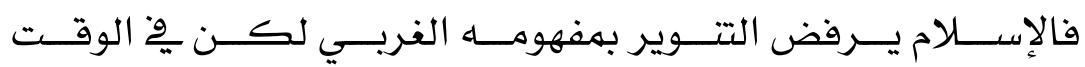

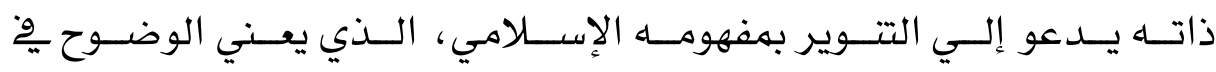

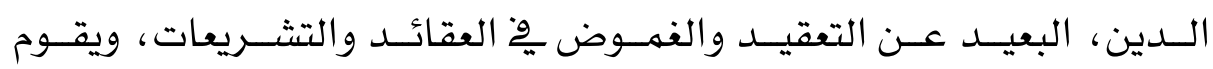

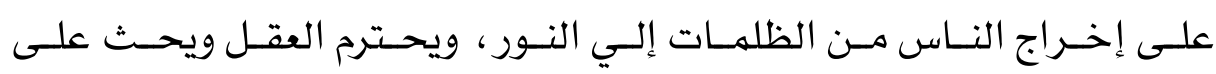

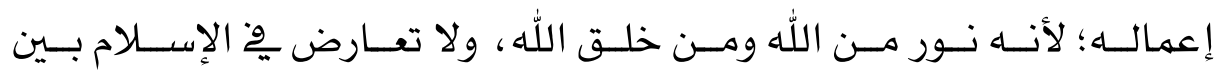

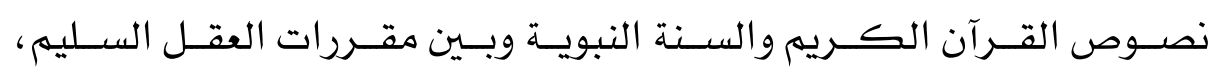
والحقائق العلمية.

ويعهــل التــوير الإســلامي علـى الترابـطـ والتكـامـل بــين الفطــرة

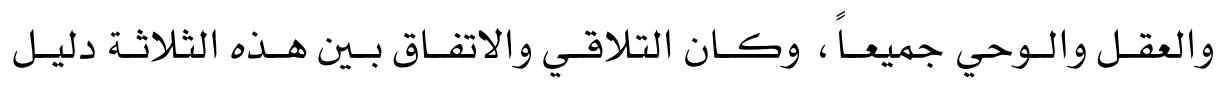
صدقها ، والاختلاف بينها دليل الانحراف فيها أو ِِّْ بعضها.

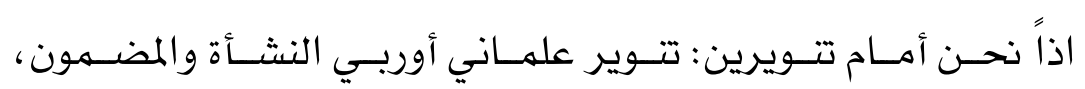
وتتوير إسـلامي قائم على الجمع بين النص الصحيح والعقل السله. ومدار البحث يدور حول هذا لذا جاء

بعنوان (التنوير الغربي والتنوير الإسلامي) دراسة مقارنة. 


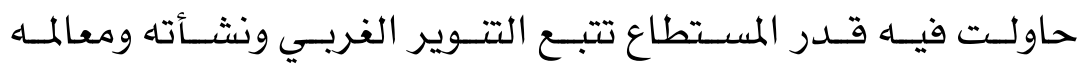

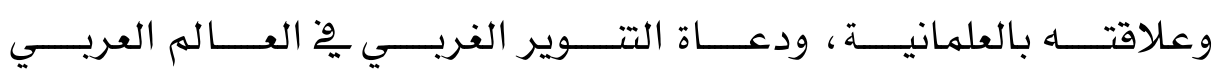

$$
\text { والإسـلامي، وبيان التتوير الإسـلامي ومقوماته. }
$$

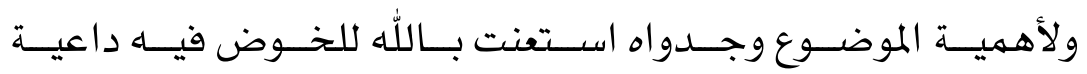

$$
\text { الله التوفيق والقبول. }
$$

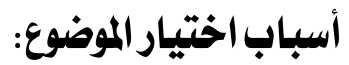

كان لاختيار الموضوع أسباب عدة منها :

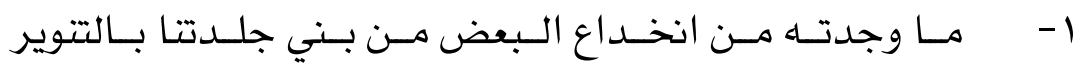

$$
\text { الغربي، بل محاولة بثاه ونشره يخ العالى العربي والإسـلامي. }
$$

r- مــا رأيتــه مــن الـتلازم بـــن التيــارين العلهـاني والتتـويري فثـعرت أن مـن واجـبي كثــف زيـف هــذا التيـار ومعارضـته مـع المفهـوم

$$
\text { الإسـامي الصحيح. }
$$

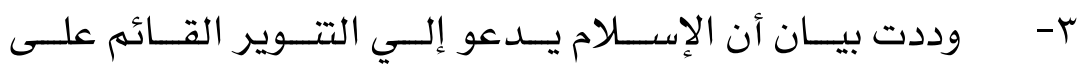

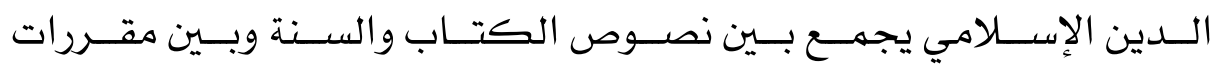

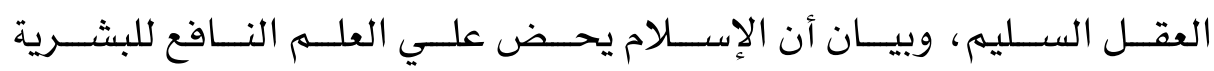
الذي يضيء العقول، ويكشف أمامها الطريق نحو الخير والرشاد.

\section{منهج البحث:}

اقتضت طبيعة البحث استخدام عدة مناهـج علمية لمعالجته.

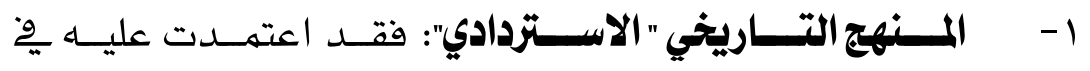
تتبع نشأة وظهور التتوير الغربي من جذوره وزمنـه، ومعالمها. 


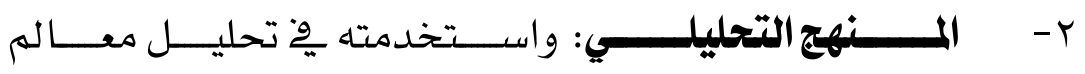

$$
\text { ومقومات التتوير سواء الغربي أو الإسـلامي. }
$$

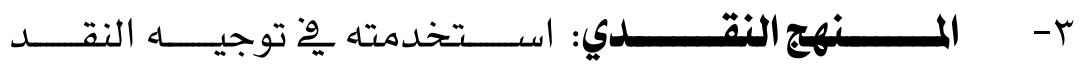

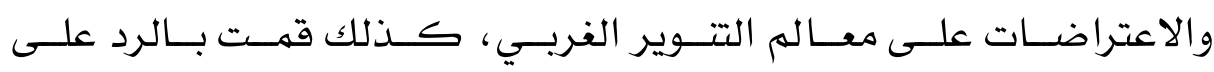

$$
\text { دعاة التتوير يخ العالم الإسـلامي. }
$$

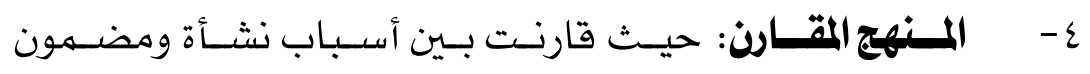

$$
\text { خطة البحث: التتوير الفربي وبين نشأة ومضهون التوير الإسـلامي. }
$$

يحتوي البحث على مقدمة، وثلاثة فصول، وخاتمة.

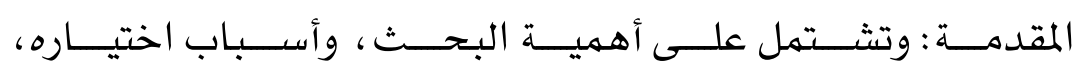

$$
\text { ومنهج البحث ، وخطته. }
$$

الفصل الأول: التنوير الغربي وهقوهاته.

$$
\text { ويشتمل على مبحثين: }
$$

المبحث الأول: معني التتوير الغربي ونشأته.

$$
\text { المبحث الثاني: مقومات التتوير الغربي. معني التوير الفربي واتيات }
$$

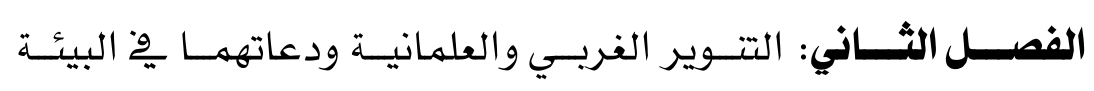

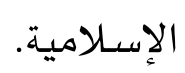

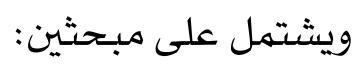

المبحث الأول: العلاقة بين التتوير والعلمانية. المبحث الثاني: دعاة التتوير الفربي يُّ البيئة الإسـلامية. 


$$
\begin{aligned}
& \text { الفصل الثالث: التتوير الإسـلامي ومقوماته. }
\end{aligned}
$$

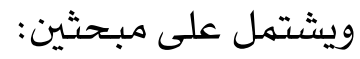

$$
\begin{aligned}
& \text { اللبحث الأول : مفهوم التتوير الإسـلامي ومصدره } \\
& \text { المبحث الثاني : مقومات التتوير الإسـلامي. }
\end{aligned}
$$

الخاتمة: وتشتهل على أهم ما تهخض عنـه البحث من نتائج.

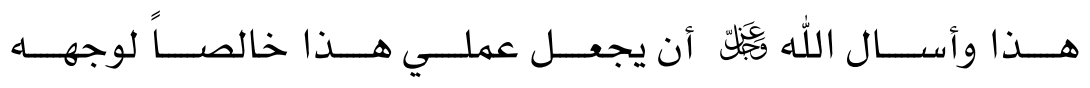

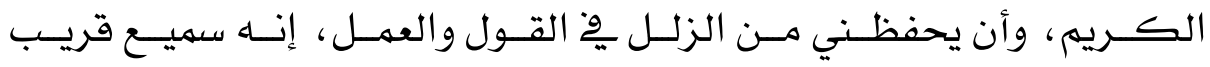

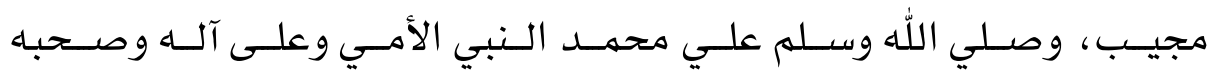

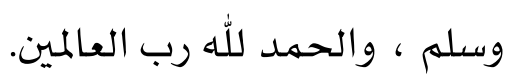




\section{التنوير الغرجيَ والتنقويَيَ الإسلامي \\ الفصل الأول: التنوير الغربي ومقوهاته.}

$$
\text { ويشتمل على مبحثين: }
$$

المبحث الأول: معني التتوير الغربي ونشأته.

$$
\text { المبحث الثاني: مقومات التتوير الغربي. }
$$




\section{الإبحث الأول \\ معني التنوير الغربي ونشأته}

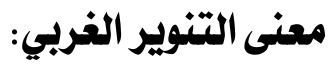

مصــطلح التـــوير حسـديث النشــأة وخصوصـيته بحركـــة أوربيـة

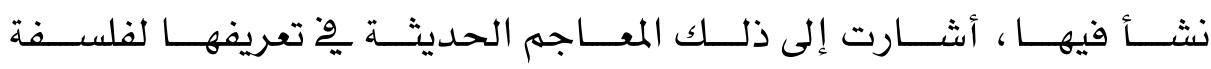

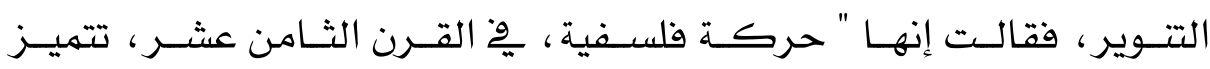

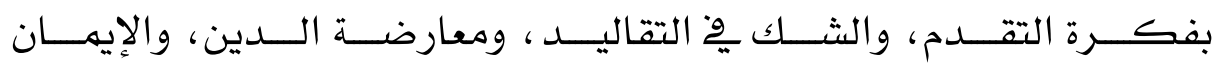

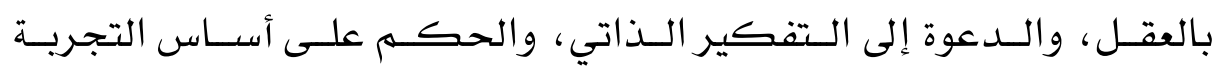
الشخصية ، والتفاؤل بتأثير التعليم مِّ الإصلاح الأخلاقي "(1).

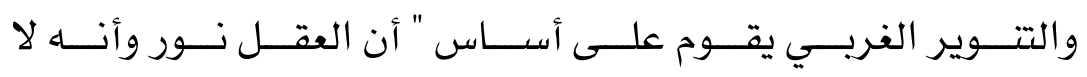

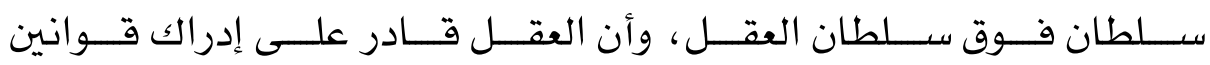

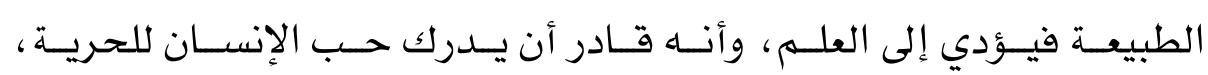

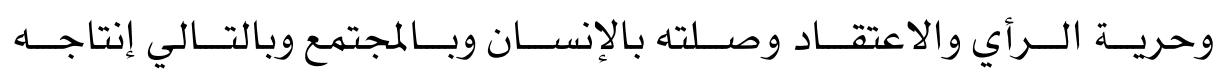

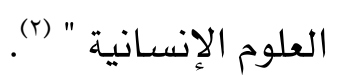

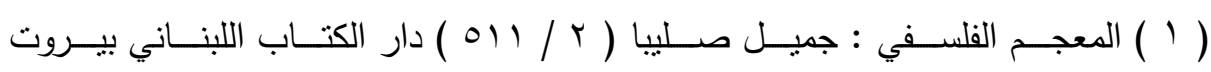

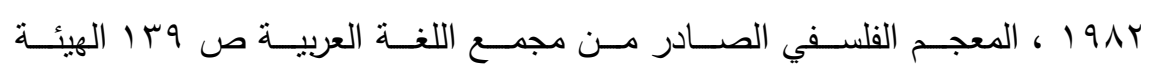

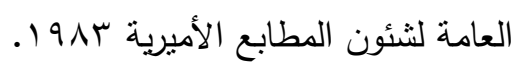

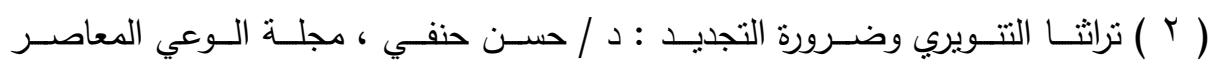

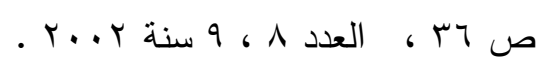




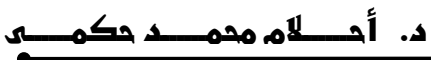

\section{التنوير الغريهي والتنيويجي الإسلاميي درأستمقارئي}

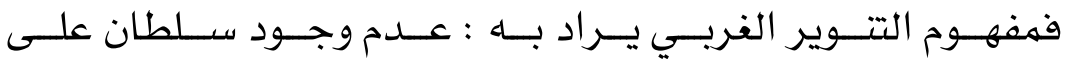

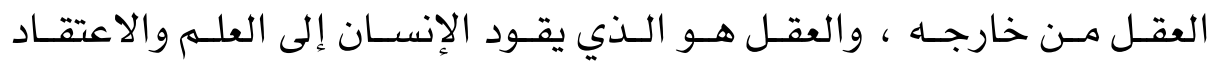

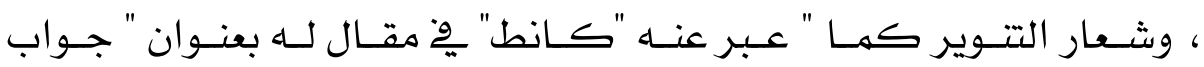

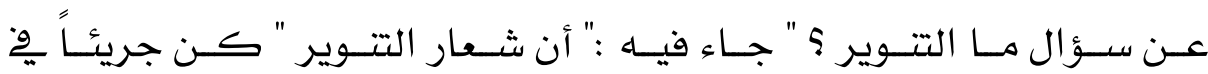

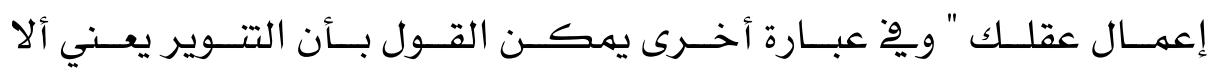
سلطان على العقل إلا العقل ذاته "(1).

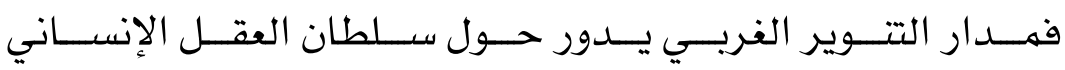
وحده وتحريره من كل السلطات، والعقائد التي تعيق استخدامه.

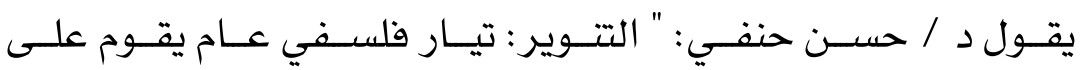
العقـل والطبيعـة والإنســان والحريــة والمســاواة والتقــدم، وهـــي المفــاهيم

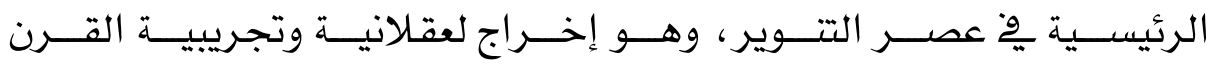

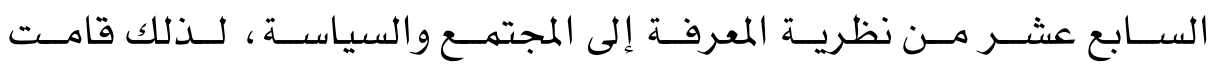

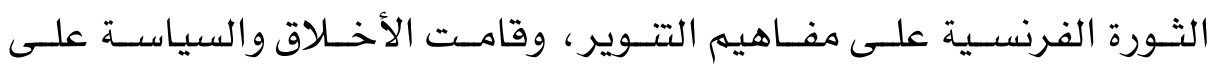

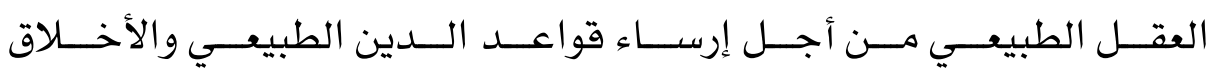
الطبيعية "(r)

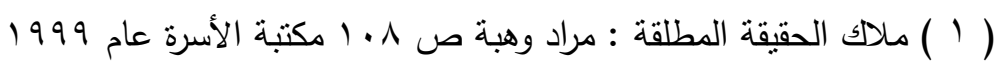

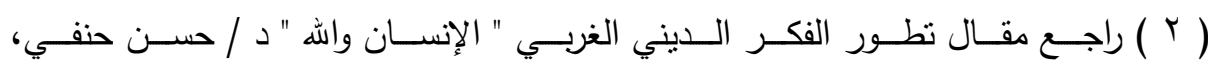

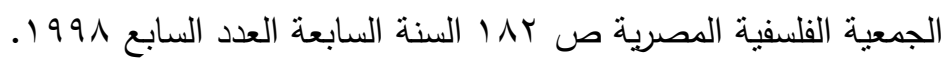

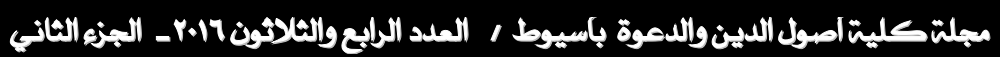




\section{التحديد الزمني لعصر التنوير الغربي:}

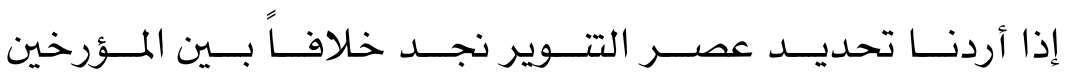

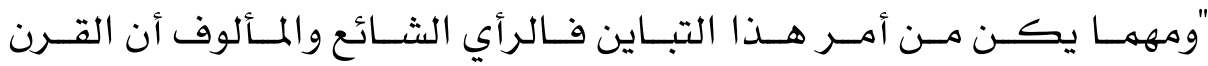

الثامن عشر هو عصر التوير" (1).

وهــا القـرن " شــهد صـعود موجـة فلسـفة التــوير ، وتـولي أعـلام

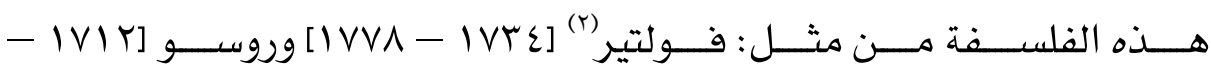

[l VVA حتى لقد سهي هذا القرن الثامن عشر بعصر التتوير "(†).

( 1 ) مــخل إلـى التتـوير د / مـراد وهبـة ص ^1 دار العـالم الثالـث مصـر ط ا ســنة $.199 \varepsilon$

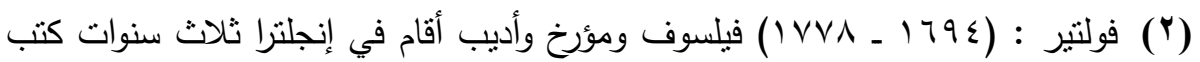

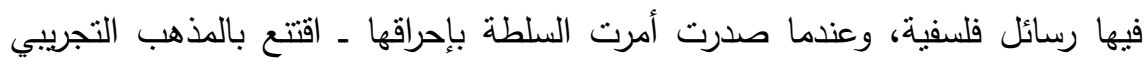

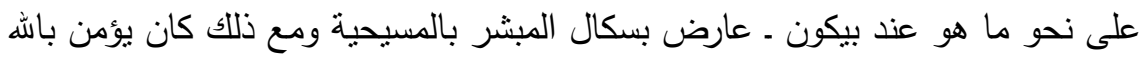

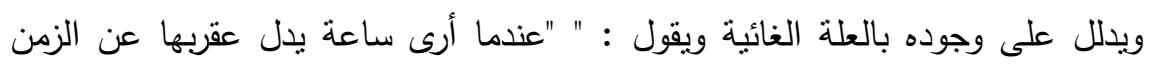

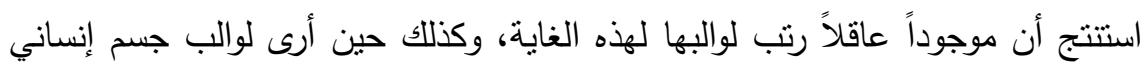

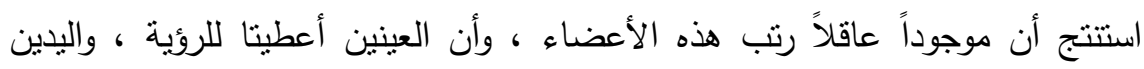

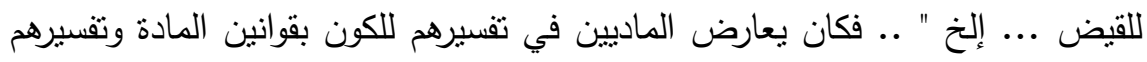
للأنواع الحية بالتوالد الذاتي وبالنطور على ما نتاء الصدفة، وكان يرفض فئن النطور لأنه يشكك في أن نكون الأجناس التبشيرية نفسها وليدة تطور أصل واحد" تاريخ الفلسفة

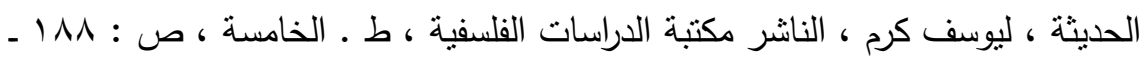
.119

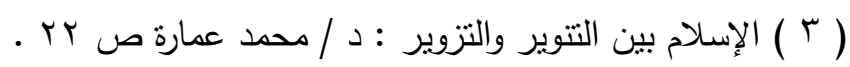




\section{نشأة التنوير الفربي:}

" لعـل كلهـة التــوير الـتي تقابلـها كلهــة الظـلام تمثـل مفهومـاً

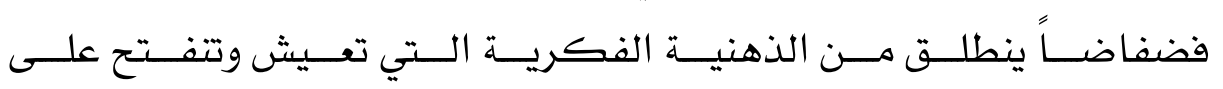

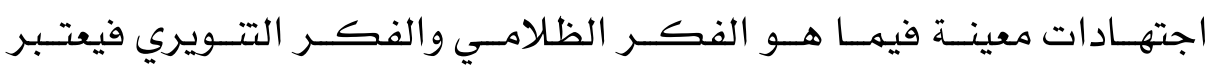
فكره تتويرياً لأنه يرى فكراً آخر ظلامياً" (1).

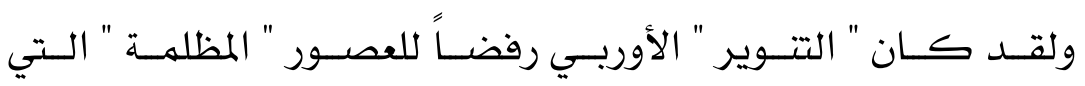

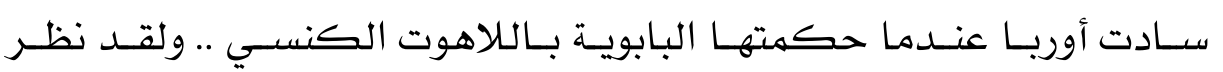

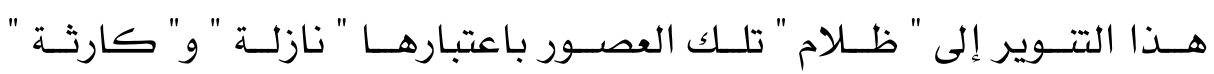

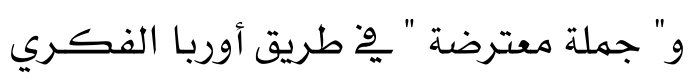

فتقــدم فلاسـفتها لطــي هـــه الصـفـحة، وإحـلال التــوير محلـها ..

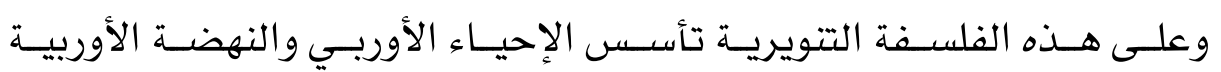

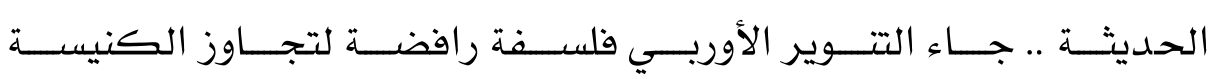

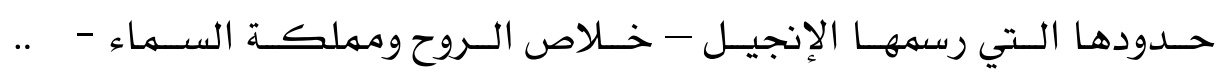

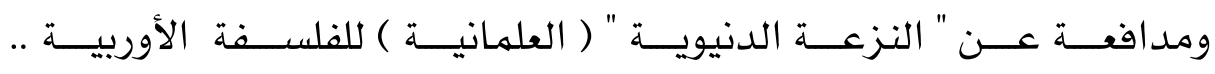

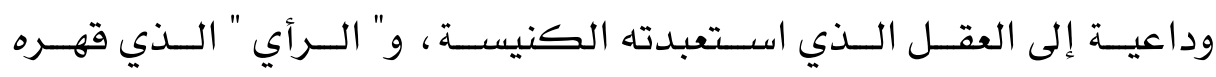

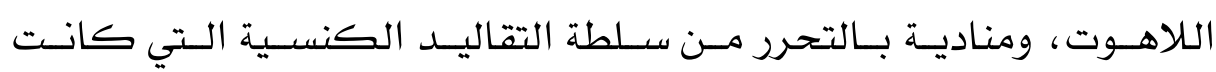

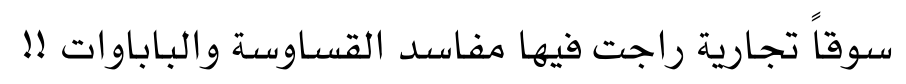

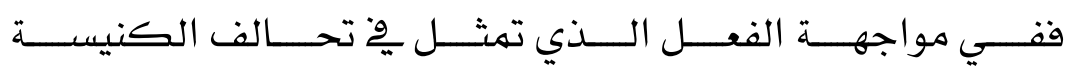

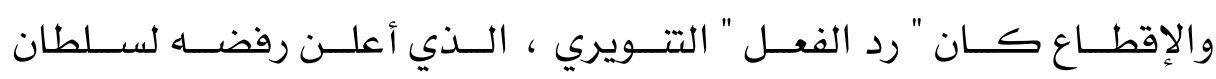

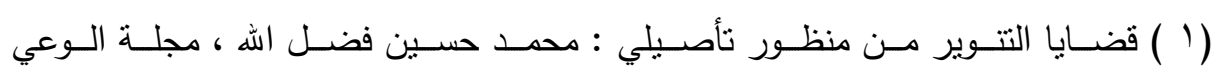

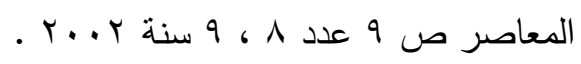




\section{التنوير الغريجي والتينوير الأسلامي

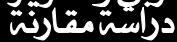

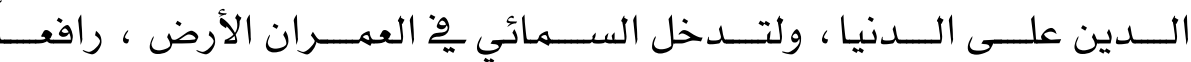

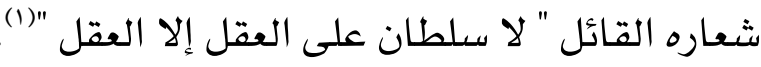

$$
\text { يقول د / محمود حمدي زقزوق : }
$$

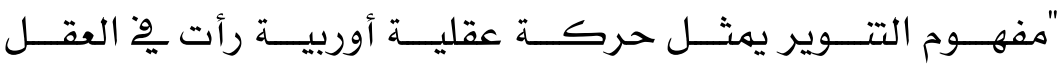

الوجــود الحقيقـي للإنســان، وســت إلى تحريــر الحضـــارة مــن الوصــايا

الكنســية والنزعــات الغيبيــة والخرافـات، ودعــت إلى التســـامح وآمنــت

بتقـدم الإنسـانية عـن طريـق تشــكيل الحيـاة على أسـس طبيعيـة وعقليـة ودئ

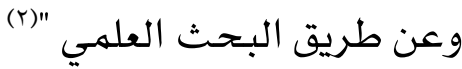

لقـــد نشــأ التـــوير الغربــي الــذي رفـض مهـا هـــو خــارج العقـل

الإنســاني ورفض سـلطان الــدين رد فــل للظـلام الغربـي الــذي ســاد أوربـا

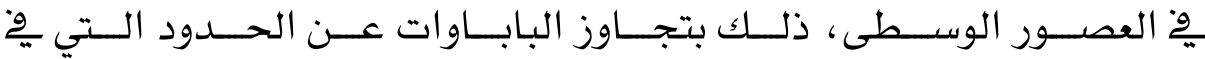
الإنجيل، والسيطرة على الفكر والعقل، لكورل،

وحصـر الفكـر علـى الفكــر الأرســـي الـــي تبنتـهـ الكنيسـة، ،

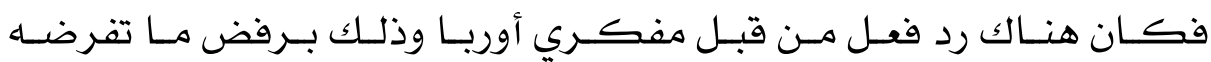

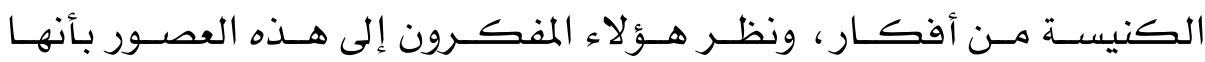

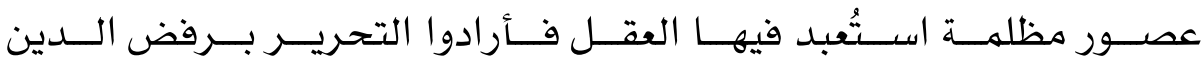

الكنســي ولا سـلطان إلا للعقـل الإنســاني. وعلـي الجملـة كــان اهتهــام

فلاسـفـة التـــوير بقضــايا العـالم الــراهن، ولــيس العــاله الآخــر .. ولهم

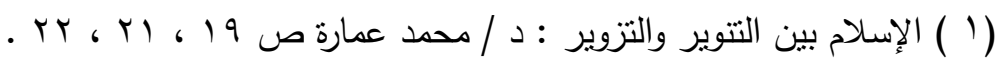

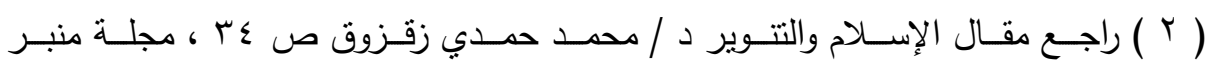

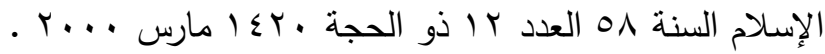


تكـن مهمـة التــوير الأسـاسـية معرفـة طبيعـة الإنسـان، وإنهـا تفـير سـلوك

الإنسـان على أسس عقلانية ومادية. (1)

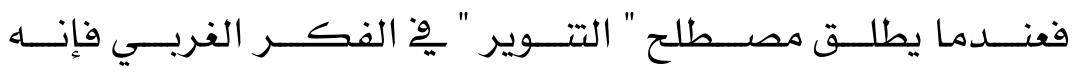

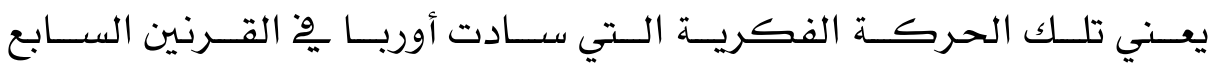
عشـــر والثــامن عشــر، والــتي مثلـت ثــورة باســم العلــم والعقـل والحريــة

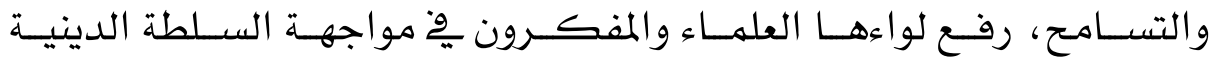

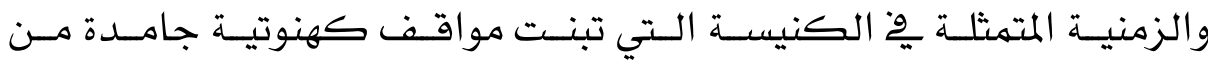

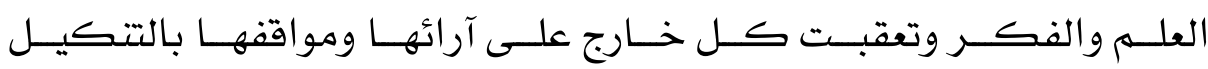
والأذى، كها تجسد ذلك جلياً ِِّ2 العصور الوسطي المظلمة بِّ أوربا. تقـول الـــكتورة / زينـب عبـــ العزيـز : "عصـر التــوير ... يهثـل

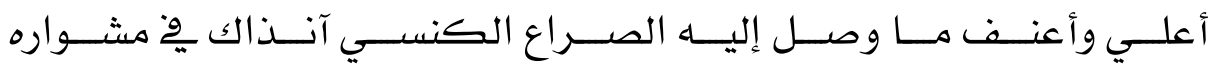

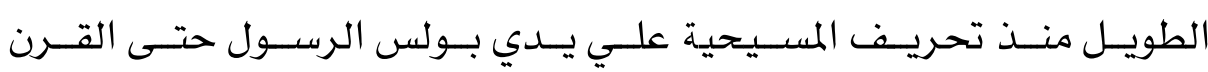

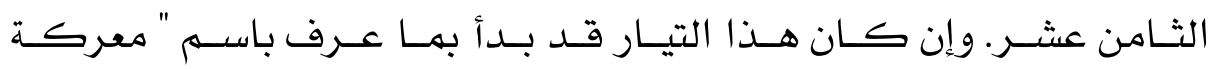

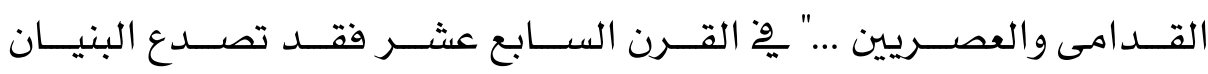
السياسي والأخلاقي والديني منذ ما عرف " بأزمة الضمير الأوربي "

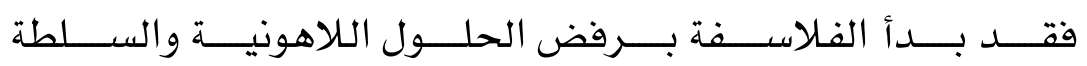
التقليديـة المتوارثـة وراحـوا يراجعـون المفــاهيم الأسـاسـية المتعلقــة بهصـير 


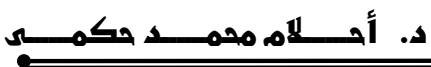

\section{التنوير الغريجي والتنويجي الإسلامي دراستيمقارئي}

الإنسـان وتتظـيم المجتهـع. إيمانـاً بالعقـل الإنســاني القـادر علـى حـل كـل

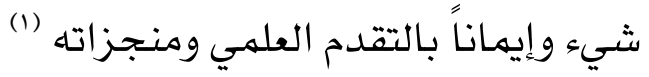

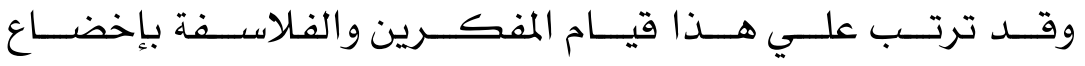

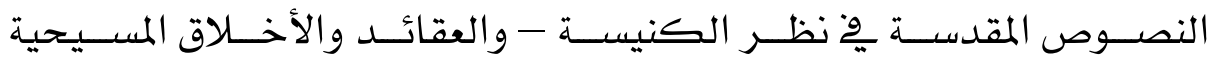

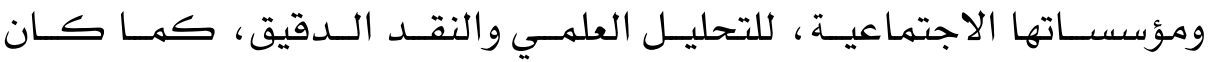

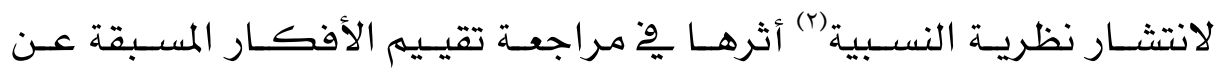

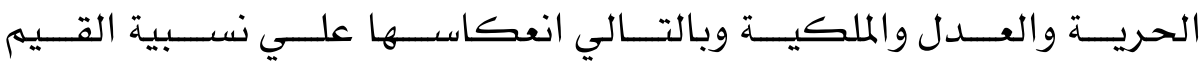

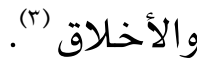

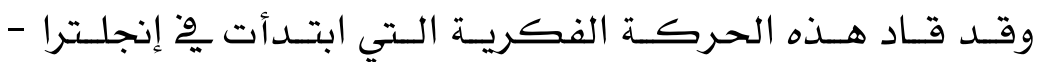

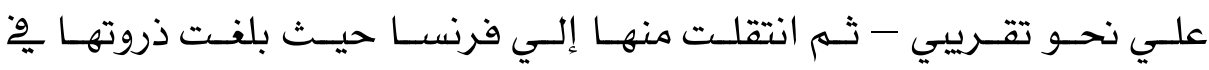

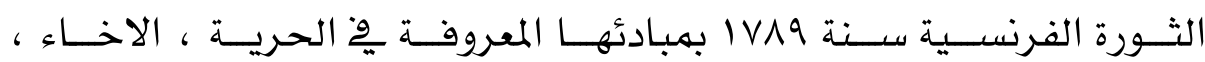
المساواة ، ثم عمت أوريا كلها تقريباً كثير من العلماء والفلاسفة الفية

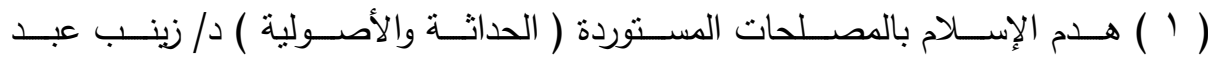

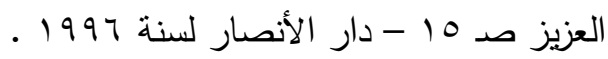

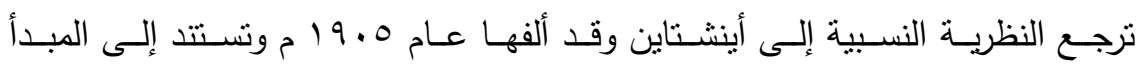

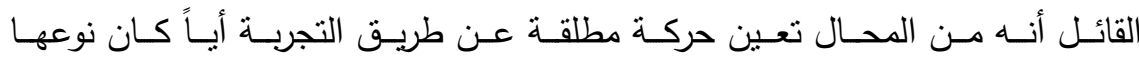

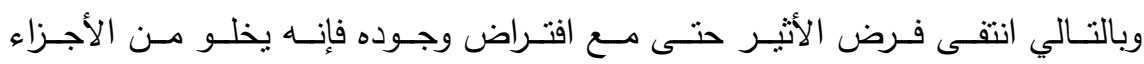

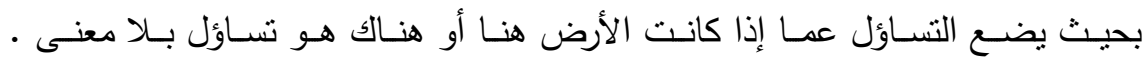

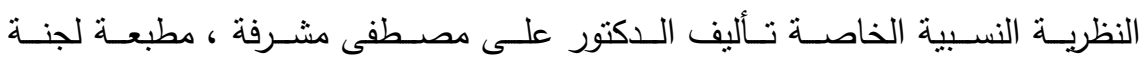

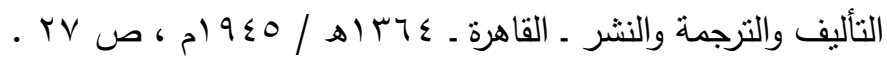

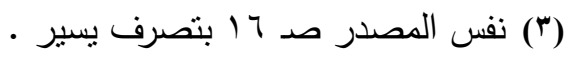




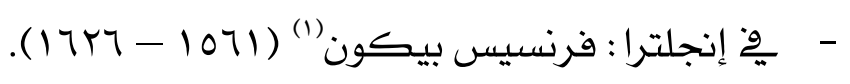

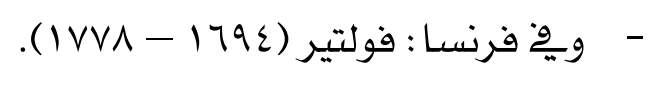

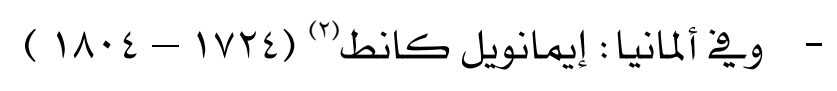

ولهـذا فقـــ تمثتل حركـة التــوير الجهـد الأكـبر الـذي اضـطلع

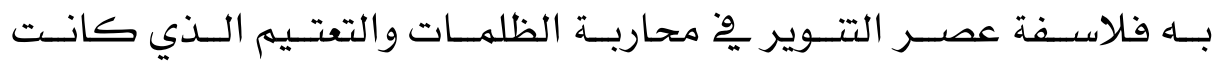

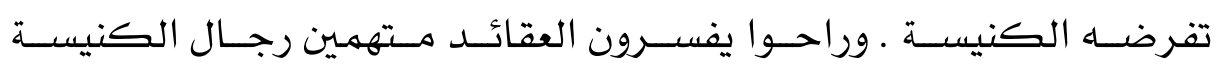

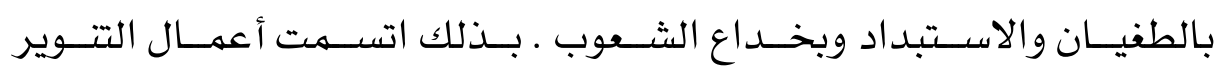

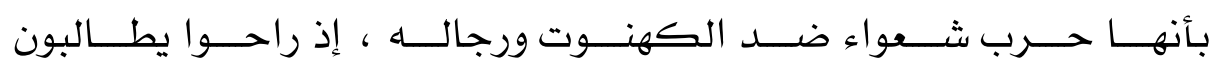

(1) فرنسيس بيكون : (1071 م ـ 1747 م) فيلسوف انجليزي تجريبي له رسالة بعنوان

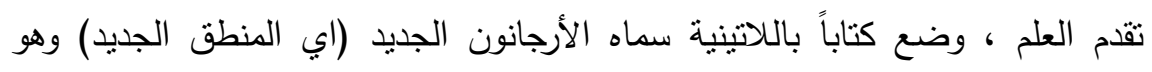

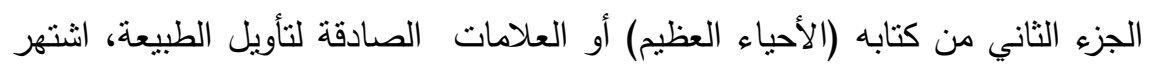

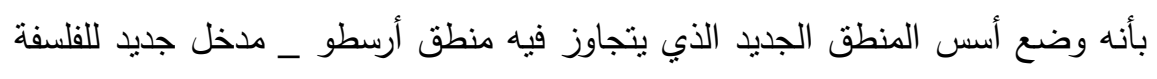

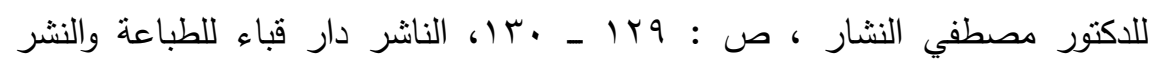

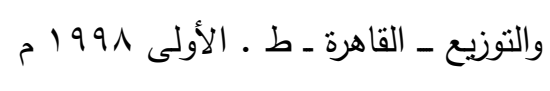

كانط : فيلسوف ألماني كان متأثراً بنيونن ونشر كتابه التاريخ العام للطبيبعة ونظريـة

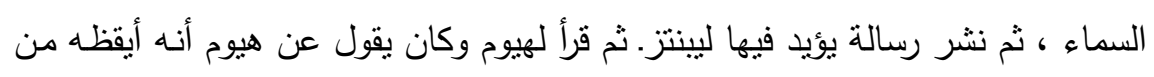

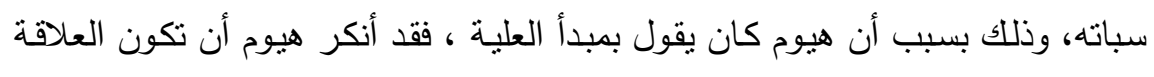

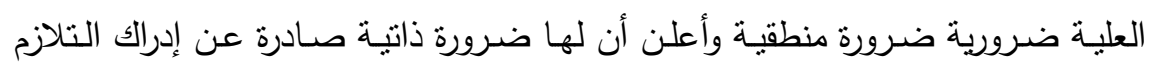
وتكراره ، ثم ذهب كانط إلى أن العقل عاجز عن إدراك الأثشياء في حقيقتها وأسمائها

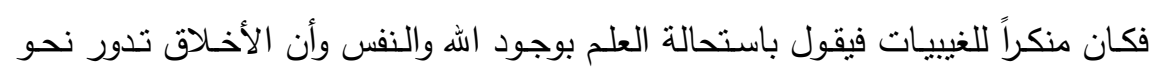

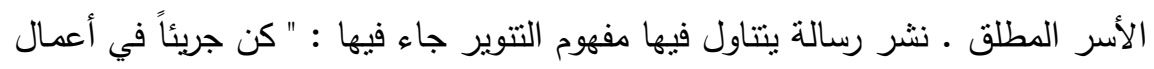

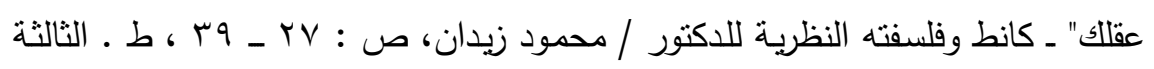

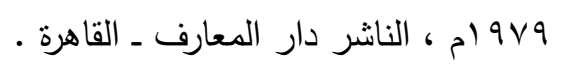




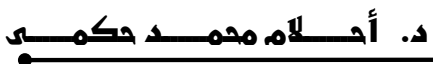

\section{التنوير الغريهي والتنيويجي الإسلامي دراستيمقارئي}

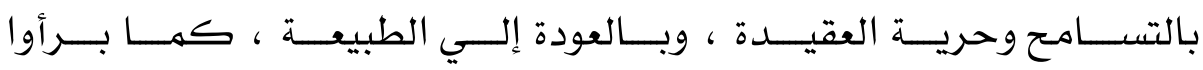

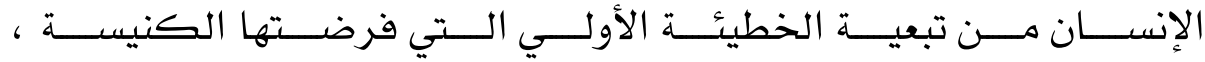

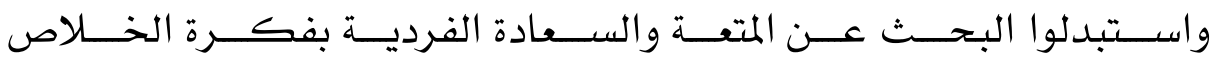

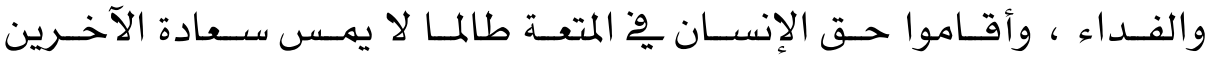

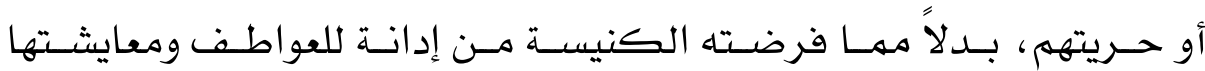
وفرضها للحرمان والتبتل (1) بهدهان

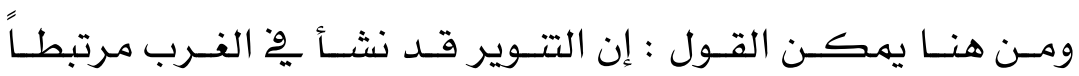

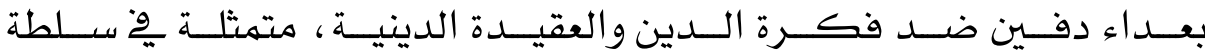

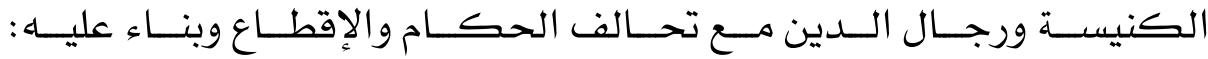

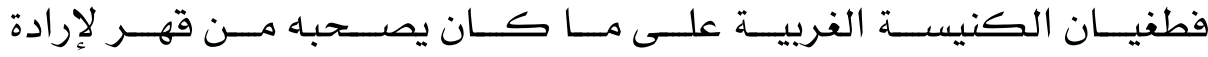
الإنسان أدى إلى نشأت التتوير ·

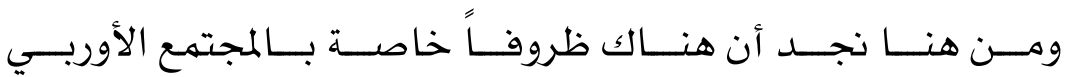

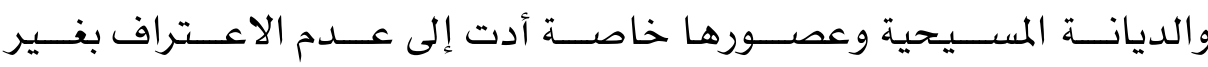
العقـل فنشــأ مـا يسـهـى بــالتتوير ، وسهـــي عصــر هــــه المرحلــة أوربــي

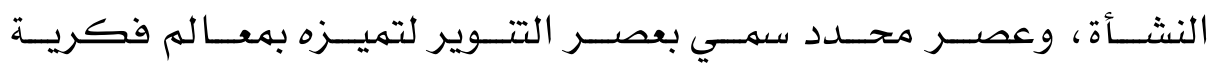

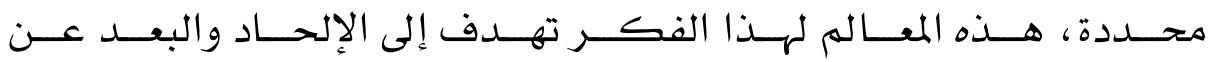

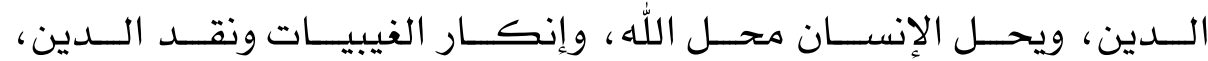
وتقرير أن العقل لا سلطان عليه من خارجه.

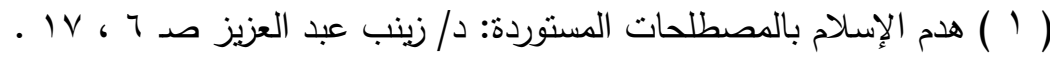




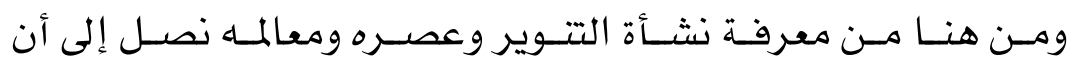

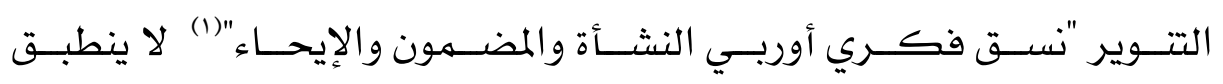

$$
\text { على الفكر الإسـلامي ، والتاريخ الإسـلامي. }
$$

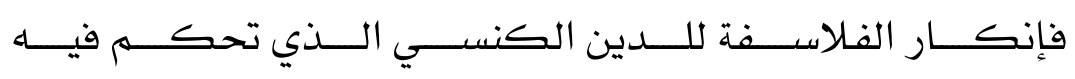

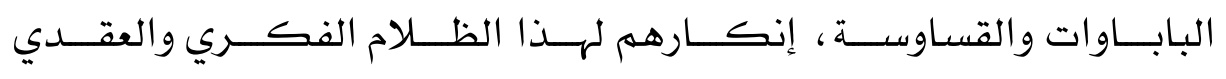
يسهى ذلك تتويراً

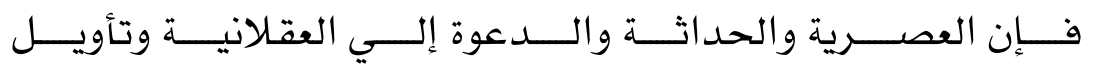

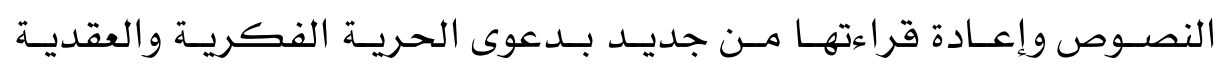

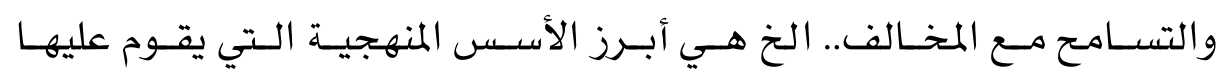
الفكر التنويري المعاصر.

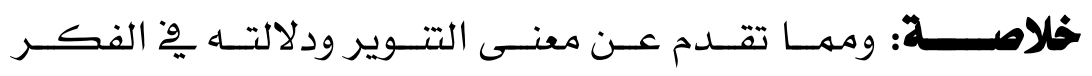
الغربي ونشأته نستتتج عدة أمور :

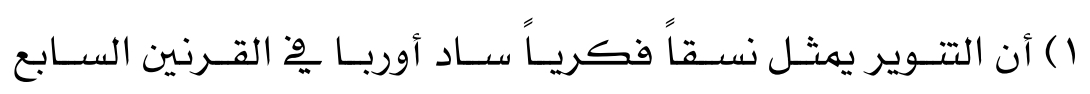
عشر والثامن عشر

r) كــان التــوير بدعوتــه إلـي العلــم والعقـل والحريـة ثـورة علـي الكنيسة وسلطتها الكهنونية المعادية للعقل والعلم.

( 1 ) الإسلام بين التتوير والتزوير : د / محمد عمارة ص 19 ـ . 


\section{المبحث الثاني}

\section{مقومات التنوير الغريب.}

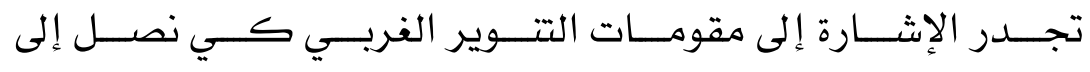

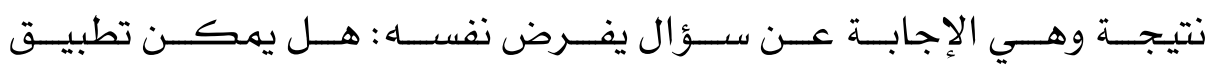

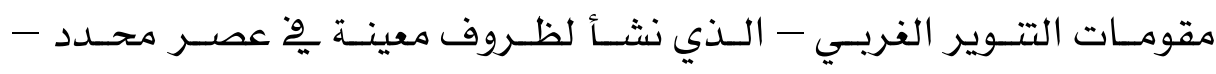
على الحضـارة الإسـلامية أو لاع

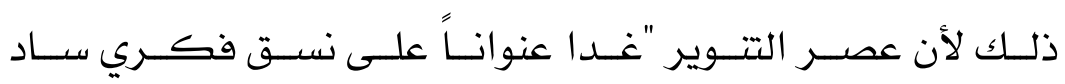

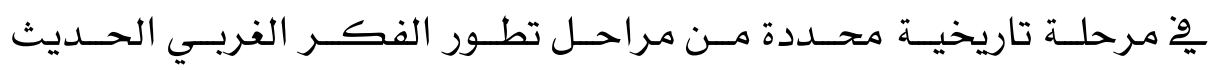

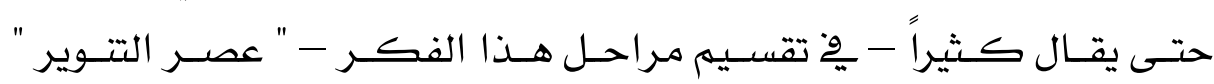

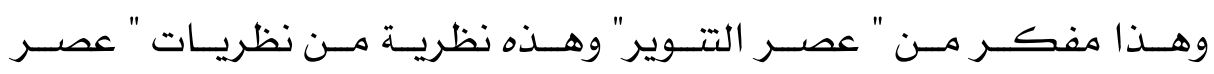

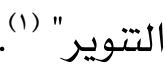

وقـــ أشــار د / محهـــ عهــارة إلى مقومــات التــوير الغربـي مــن

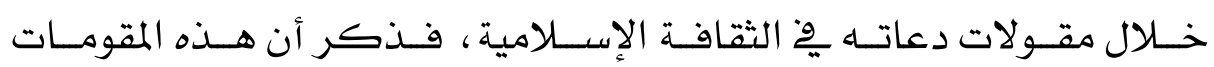
كالتالي:

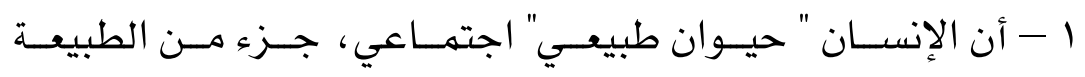

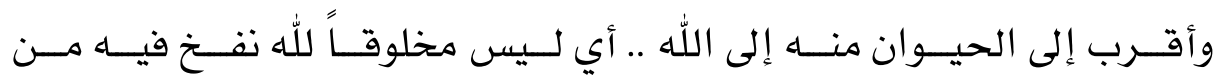
روحاه ثم جعله خليفة له.

Y - حصــر الاهتمامــات الإنســانية بقضـايا العـالم والطبيعـة، لا لا العالم الآخر وما وراء الطبيعة.

( 1 ) الإسلام بين التتوير والتزوير : د / محمد عمارة ص 19 ـ .

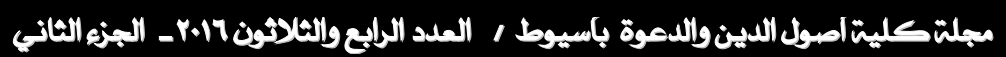




\section{التنوير الغريهي وإلتنويجي الإسلامي دراستيمقارئي}

r - تــبني " الــدين الطبيعـي " الــذي اخترعــه العقـل، لا " الــدين

السماوي " ورد الثعور الديني إلى الخوف الخرايوّ.

ع - وتحرير العقل من سلطان الدين، ليكون سلطانه مطلقًاً

0 - إحـلال العلـم محـل الميتافيزيقـا، وإحــلال التجريسة الحسـية

محل المعرفة النقلية والوجدانية .

7 - اعتبــار الفكــر وظيفــة الــدماغ، فالمــادة مصــــر الفكــر،

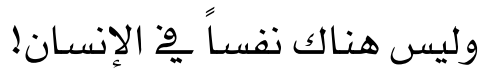

V - وجعل الإنسان هو " المطلق " بدلاً من الله والدين؛

^ - اســتبـاط الأخــلاق مــن الطبيعـة الإنســانية لا مــن الـــين،

وجعل السعادة واللذة، وليس الفضائل الروحية ، هي معيارها!

9 - إحــلال " الاجتهاعيــة " محــل " الدينيــة " ســـبيلاً للســــادة

الدنيوية؛

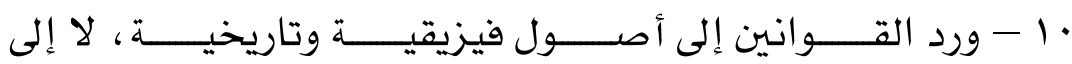

الشريعة الدينية وتحرير التاريخ من السنن الإلهية "(()

هـذه هــي مقومـات دعـاة التــوير الغربـي ذكرهــا د / عهـارة مـع

تعليقــات ســريعة عليهـا ، وتلــك المقوهـات تتســم بنزعــة ماديـة ؛ ذلــك لأن التــوير الغريـي يقـوم علـى أسـس ماديـة عقليـة بعيـدة عـن الـدين، وكــان

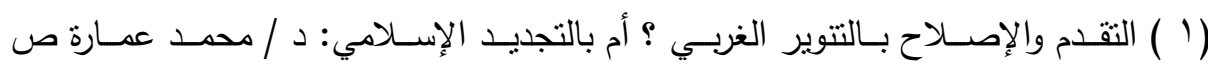

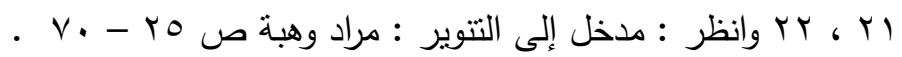




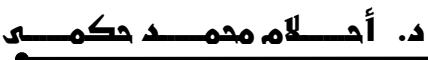

\section{التنوير الغريب والتنويجي الإسلامي

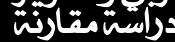

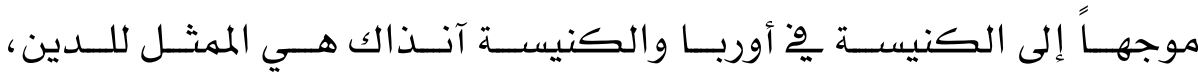
وكان يهدف إلى استقلال الفكر.

رأينـا فيهـا ســق أن فلسـفة التــوير نشــأت كــرد فنـلٍ للظـروف

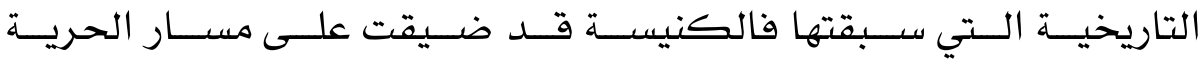

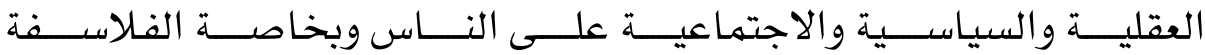
والمفكـرين والنتيجــة الحتميـة والطبيعيـة أن تتشـأ فلسـفة تــادي بالحريـة

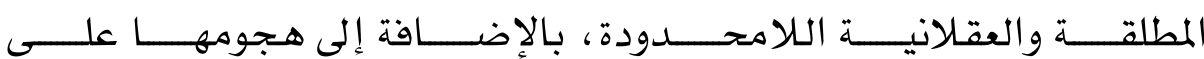
الكنيسة ، ومن ثم رفضها كل ما هو ديني. من هنا جاءت فلسفة التتوير تحمل هذه المضامين.

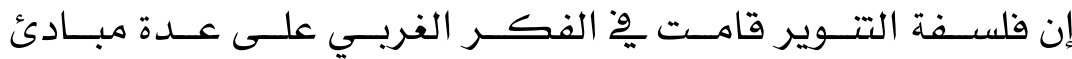

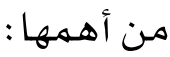
1 - تهجيد العقل (العقلانية) العقلانية المطلقة.

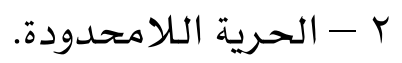

r - النظــرة الماديـة) للحيـاة والإنســان وكـل مـا يـرتبط بـهـ مـن

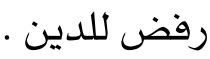

\section{أولأ: العقلانية المطلقة:}

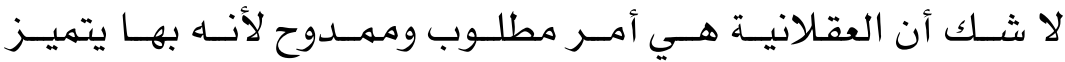

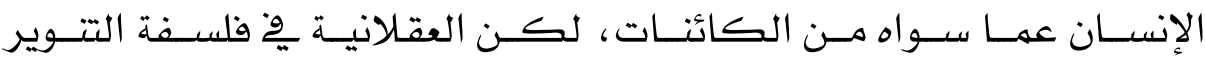

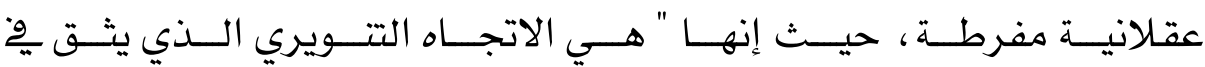




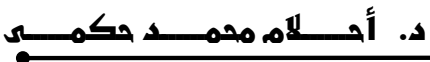

\section{التنوير الغريسي وإلتنويجي الإسلامي درأستمقارئي}

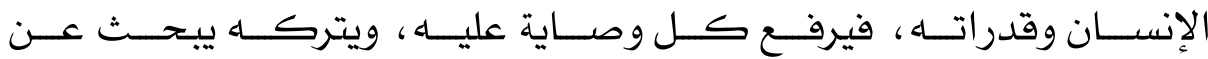

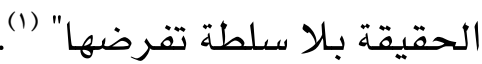

وبإمكانتــا أن نعتـبر العقلانيــة المطلقــة هــي الركيـزة الرئيســة

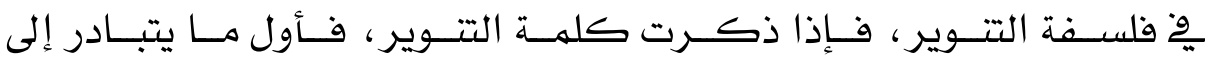
الذهن أنها الفلسفة التي تتخذ العقل شعاراً لها.

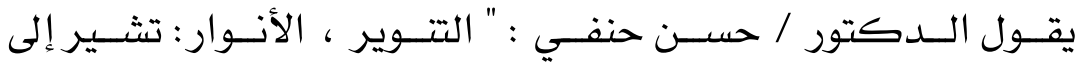

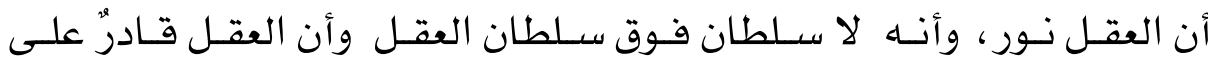

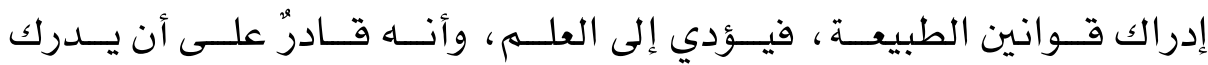
حب الإنسان للحرية وحرية الرأي والاعتقاد" (r).

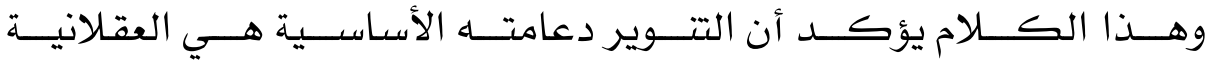

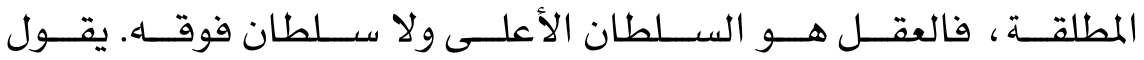

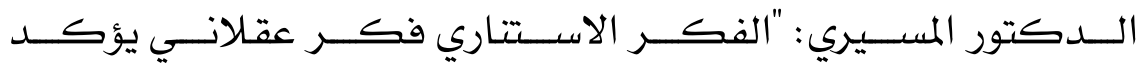

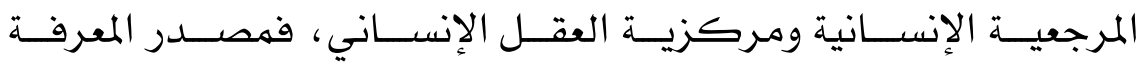

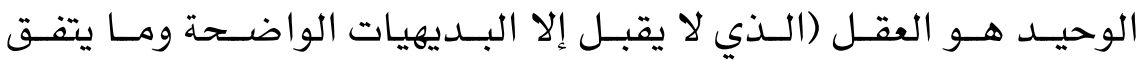

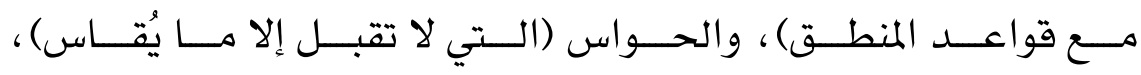

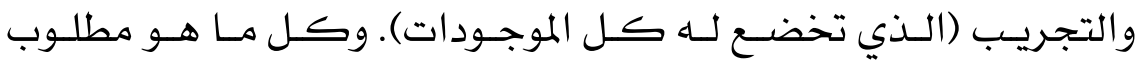

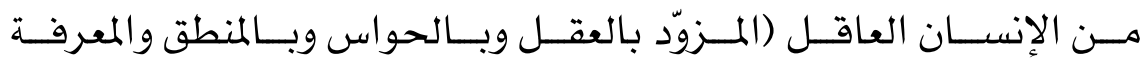

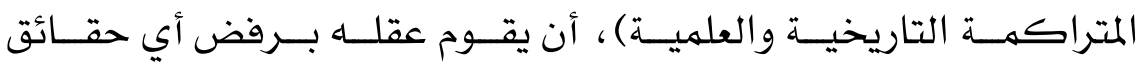

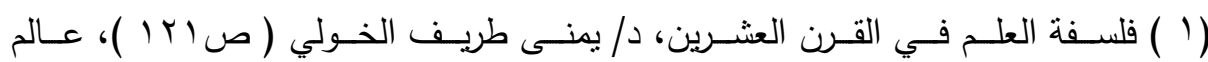

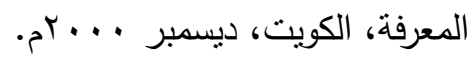

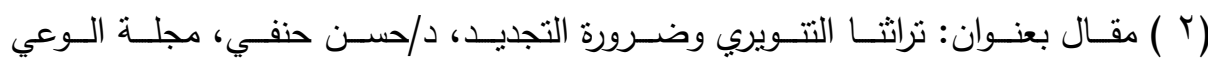

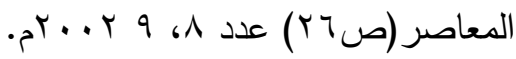


متجـــاوزة للواقــع المـــادي المحســــوس، مثـــل الأســــاطير والأوهـــــام

والغيبيات والتخيلات والحجج التقليدية والعقائد والمسلهات (1).

ولا شــك أن هـــذه العقلانيــة المطلقــة كانــت بمثابــة رد الفعـل

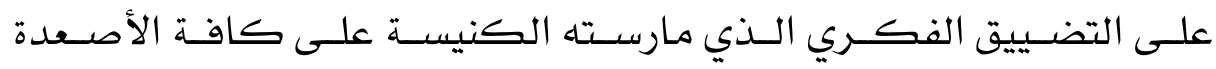
الفكرية والعقلية.

مـن هنــا " قامست هــذه الحركــة الفكريـة علـى أسـاس أولويــة

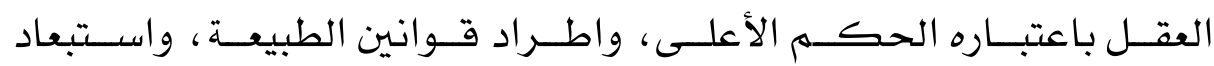

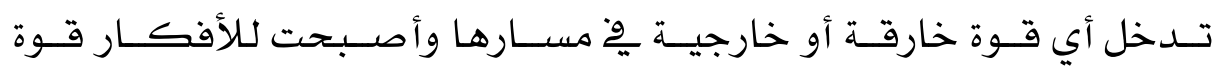

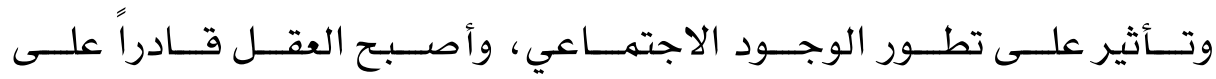

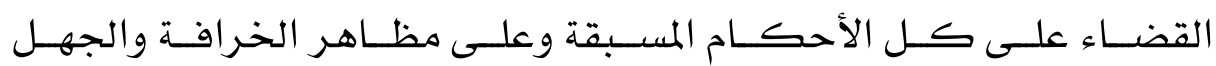

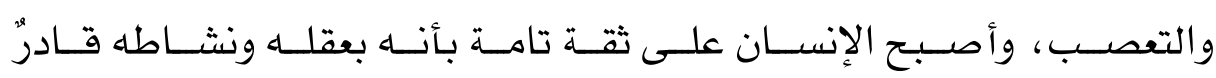

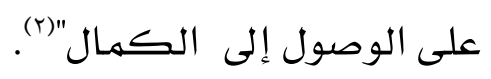

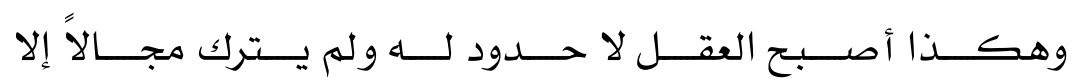

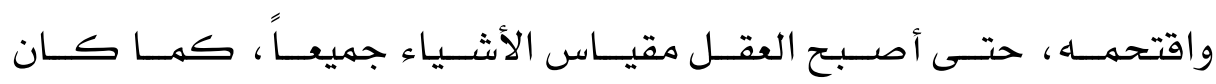

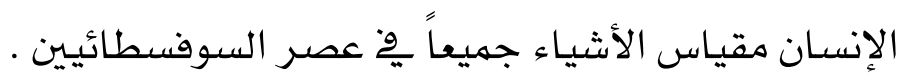
"ومـن هنــا عـرف عــن هـــا العصــر أيضــاً أنــه عصــر العقـل،

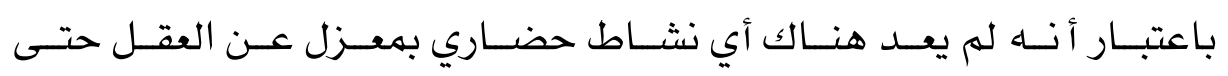
الدين نقسسه.

كرة حركة الاستتارة وتناقضاته- عبد الوهاب المسيري: (ص:ب ا )

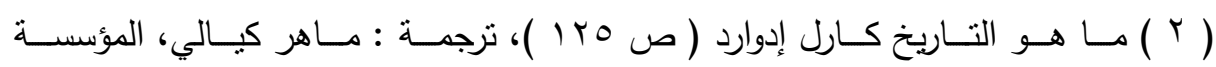

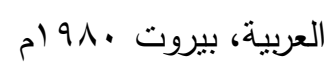




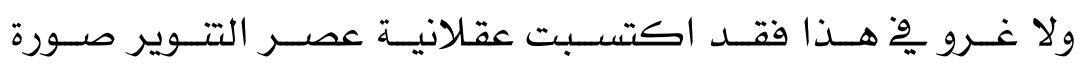

\section{الحقيقة المطلقة" (1)}

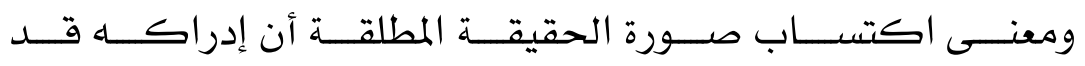

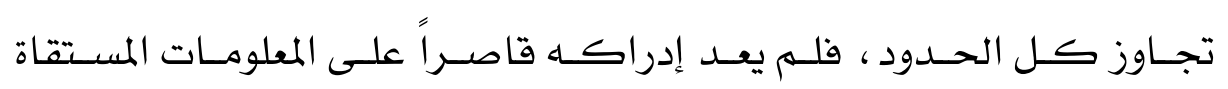
من الظواهر الحسية بل تعداه إلى ما وراء ذلك.

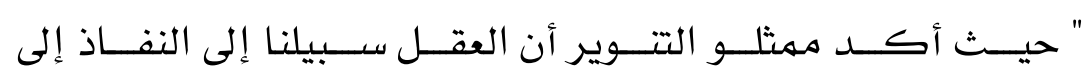

$$
\text { الحقيقة الكامنة وراء الظواهر "(r). }
$$

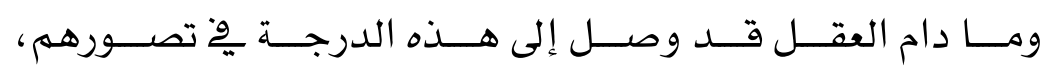

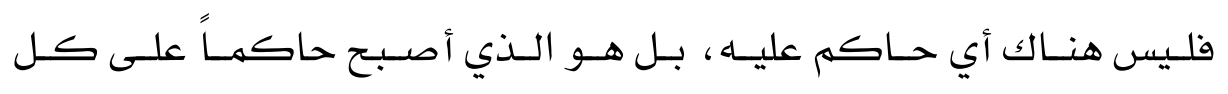

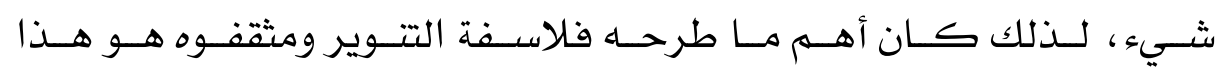
الإيهان القوي بالقدرة الهائلة للعقل.

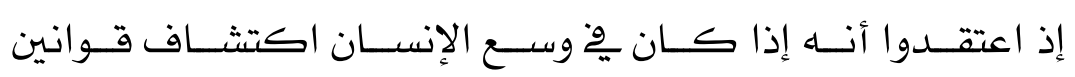

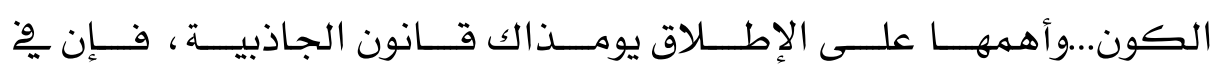

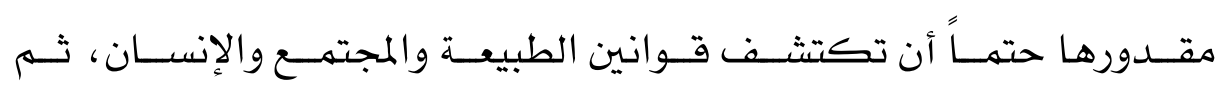

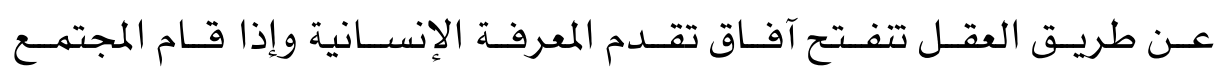
على أسـاس عقلي هادف فإنه تتحقق له السعادة والرفاهية.

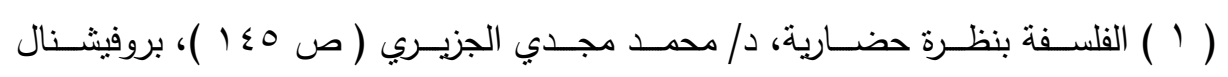

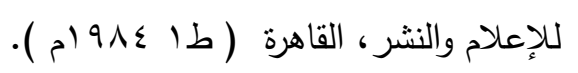

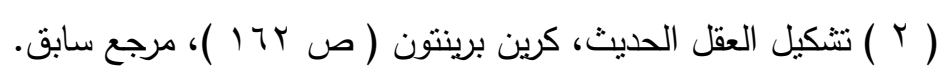




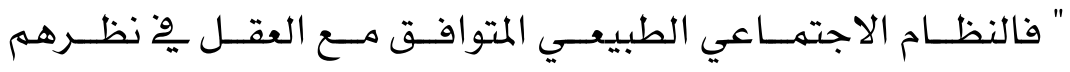

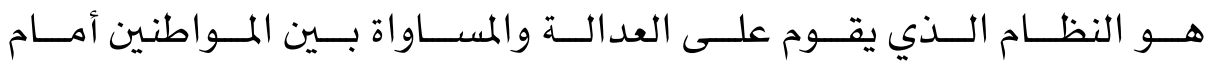

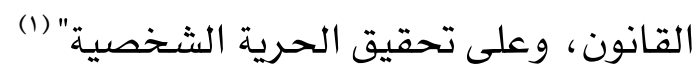

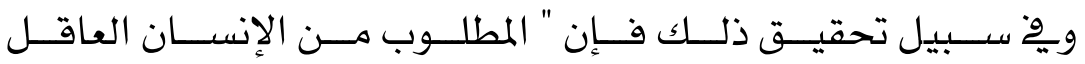

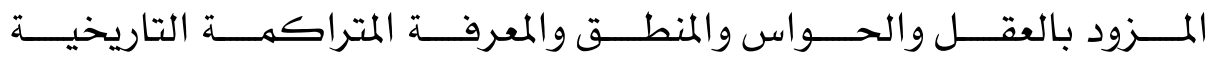

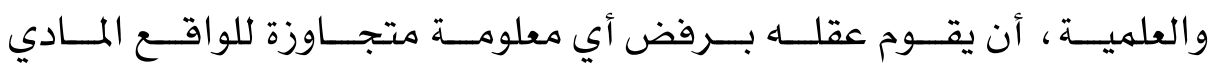

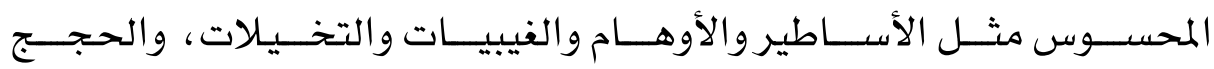
التقليدية والعقائد والمسلهات " (r).

\section{ثانياً الحرية الامحدودة:}

الحـق أن " قضـــة الحريـة مـن القضــايا المههــة الــي أثـارت وتـثير

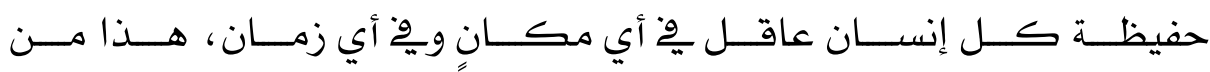

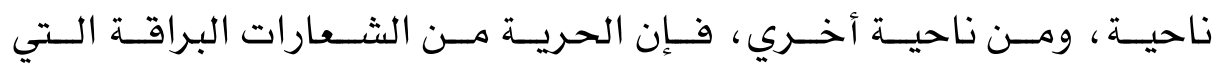

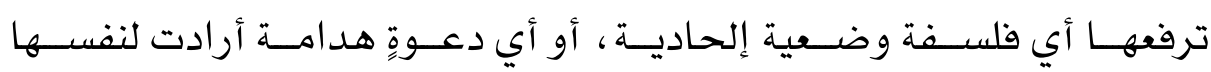
التمكن والسيطرة والغلبة ، ويرجع السبب وِّهذا هذا إلى أمرين:

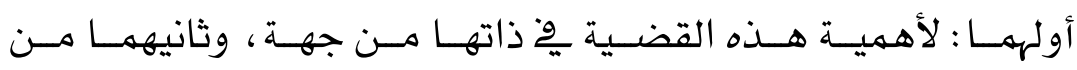

جهةٍ أخرى أهميتها بالنسبة للفرد والمجتهمع" لوهيه.

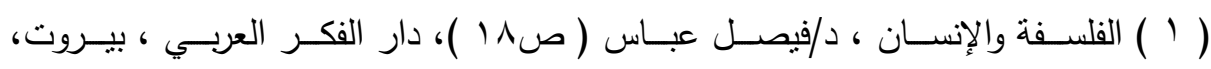

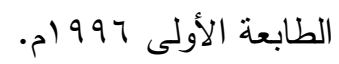

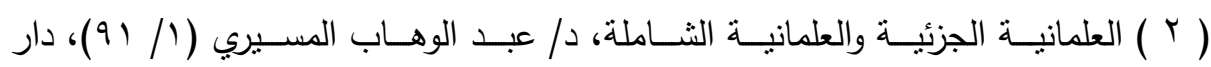

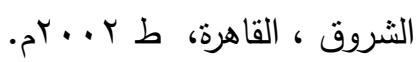

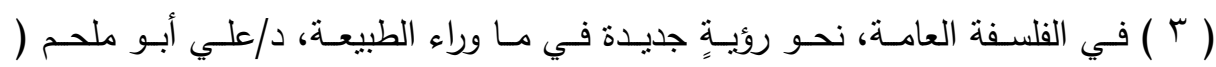

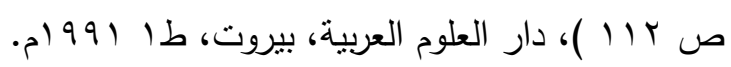




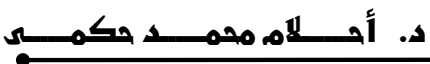

\section{التنوير الغريهي وإلتنويجي الإنلامي دراستيمقارئي}

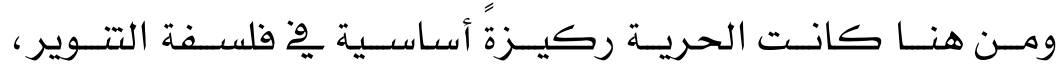

حيـث " جـاء عصــر التتـوير يْ مصــلح الغـرب لإعـلان يـوم الخـلاص مـن

مظـاهـر الاسـتبـداد والتخلـف لتصــبح الحريـة عنــده هـي عقيدتـهـ الجـديـدة

وِّ مقابـل العســف والجــور الـديني المؤسـس علـى مصـــادرة حريــة الـرأي

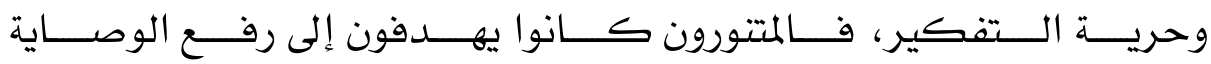

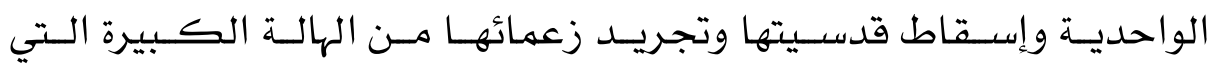
أحاطوا أنقسهم بها ،

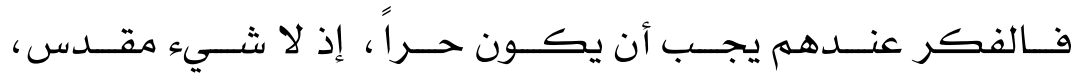

ولا شـيء معصدوم، وبـذلك فـإن الـتخلص مـن وصــاية الواحديـة المسـتبـدة مدخل أسـاسي لفهم فكر عصر التتوير" (1).

\section{ثالثاً: المادية ورفض الدين :}

نظــرة حرككـة التتـوير الماديــة : يشـير الــدكتور المســيـري إلــي

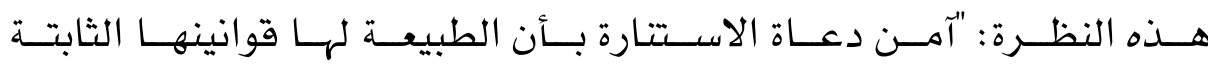

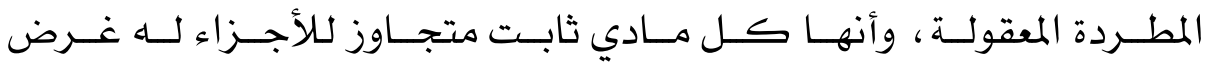
وهـــف، ولــذا فهـي مســتودع القـوانين المعرفيـة والأخلاقيــة والجماليـة ،

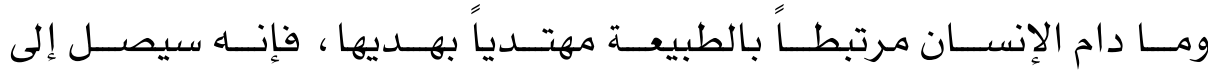
الطريـق المســقيهم ويصـل إلى المنظومـات المعرفيـة والأخلاقيـة الـتي تخــدم

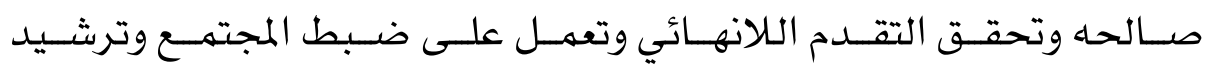

( 1 ) مجلـة الـوعي المعاصـر ، مقـال بعنـوان: الواحديـة المسـتبدة وثـورة التــوير ، حسـين

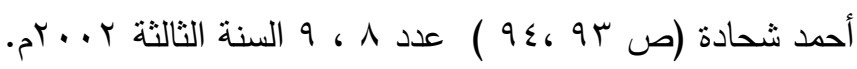




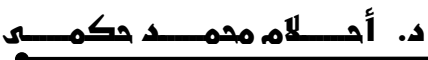

\section{التنوير الغريهي والتنتويجي الإسلاميي درأسيَمقارنيّي}

الســلوك الإنســـاني، فظهـــر الإنســـان الطبيعـــي والحقــوق الطبيعيــة، ، والدين الطبيعي والأخلاق الطبيعية"(1)

فكل التيارات المادية تتدرج تحت حركة التتوير بِّ الغرب

\section{موقف التتوير الغربي من الدين:

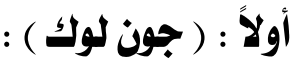

أشــرت منــــ قليـلـل أن ( جـــون لــوك ) لا يــرى الــدين ضــرورة

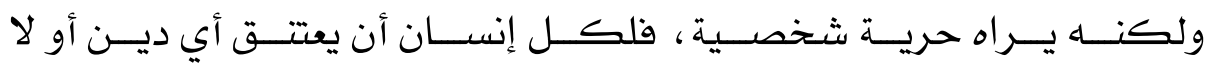

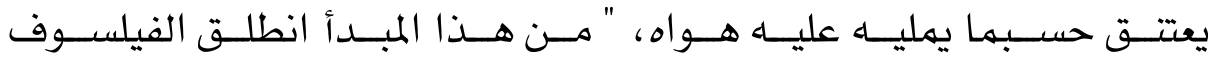

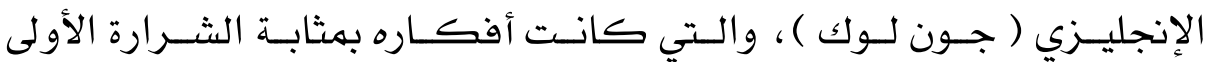

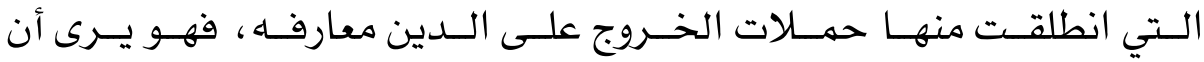

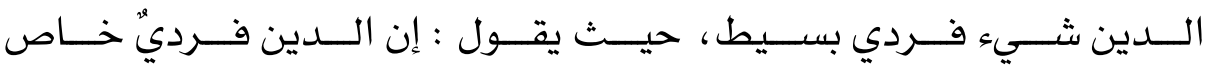

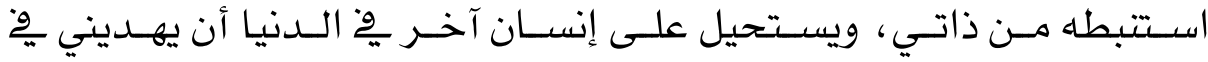

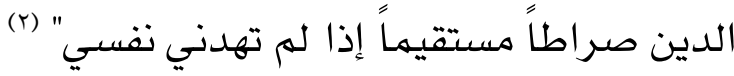
ثانياً : ( فولتير):

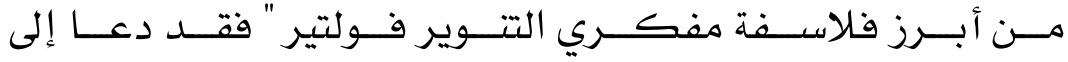

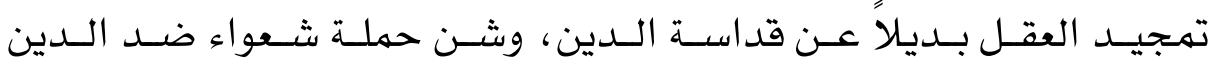
والكنيسـة ، وأنكـــر عـاله الغيـب والبحــث والجــزاء الأخـروي، وقـال إن الـنفس ليست إلا حيـاة الجسـهم، وأنهـا تقنسى بفنائـهـ .. ولـيس هنــاك وحهي

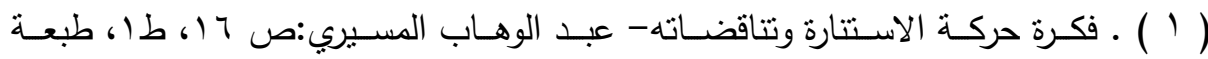

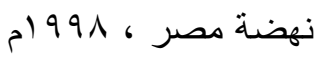

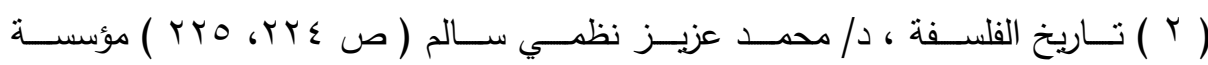
شباب الجامعة ط أولى بدون تاريخ

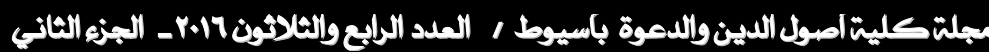




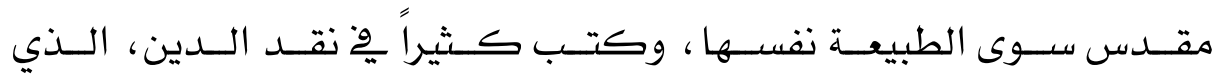

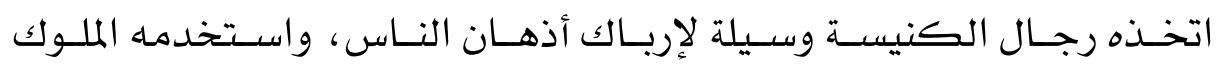

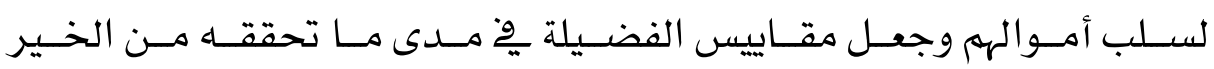

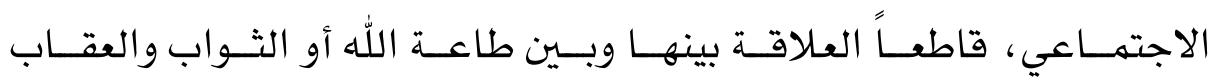
بعد الموت "(1).

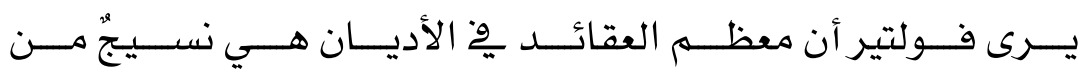

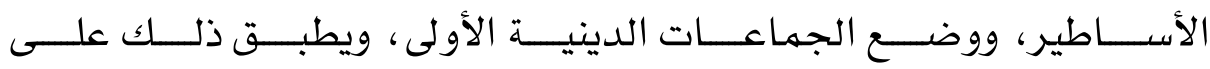
المسيحية وعلى الديانات الأخرى على السواء" (r).

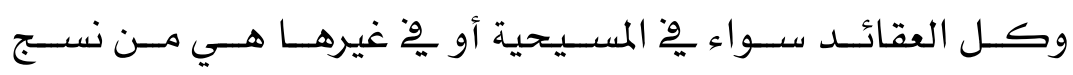
الأساطير ووحي الخيال حسبها قال فولتير.

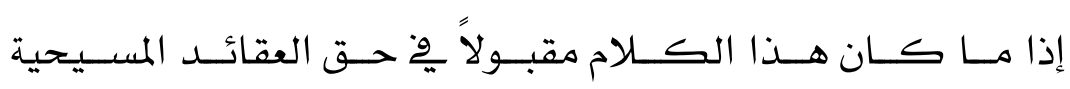

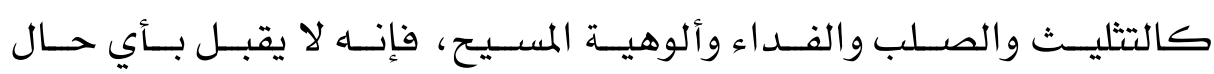

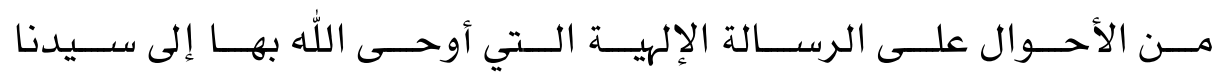
محمهـد التحريف.

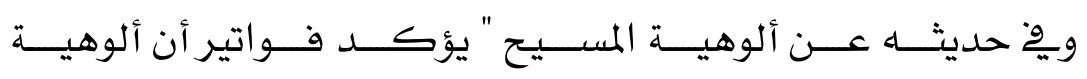

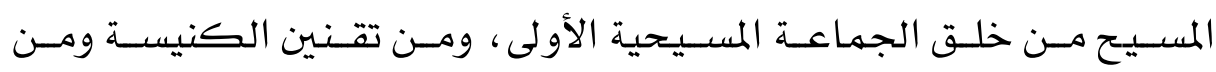

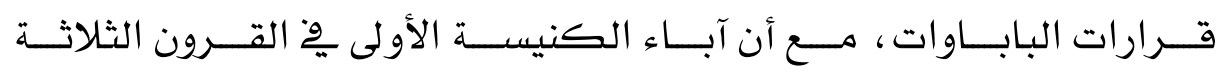

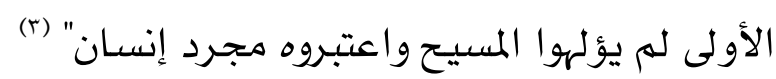

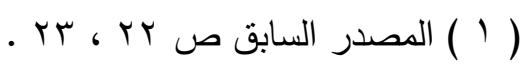

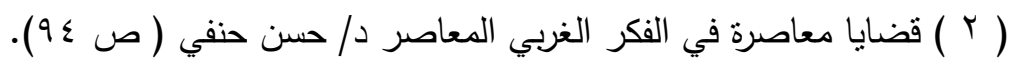

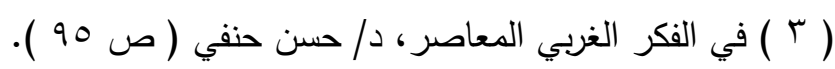




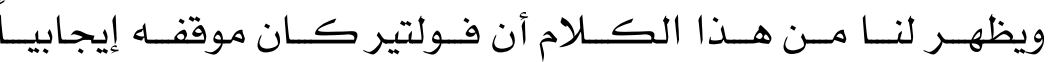

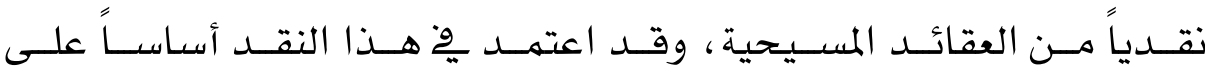

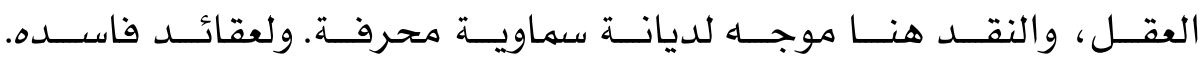
ولكتاب سماوي محرف.

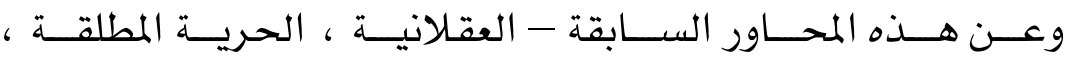

الماديـة والموقف مـن الـدين - نتجـت بـاقي النظريـات والقـيم الـتي يجعلـها

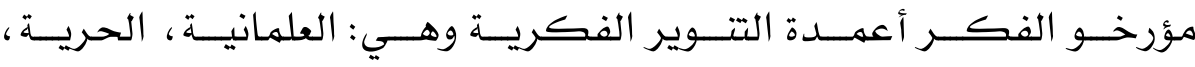

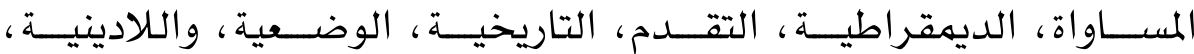
مــع التبــهـ للطبيعـة الطيفيـة لعلاقة هـذه المفــاهيم بفكـر كـل فيلسـوف

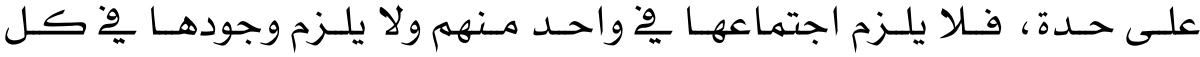
واحد منهم أو وجودهـا بنفس القوة (1)

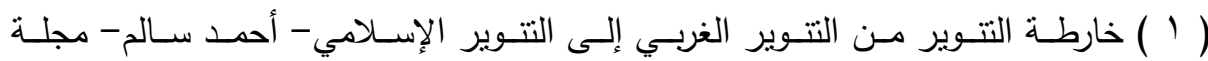
البيان. 


\section{النصل الثاني}

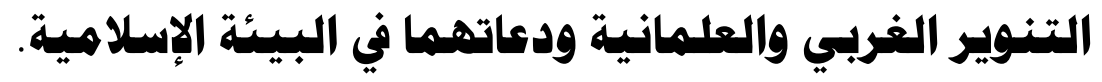

$$
\text { ولاشتمل على مبحثين: }
$$




\section{المبحث الأول \\ العلاقة بين التنوير والعلمانية}

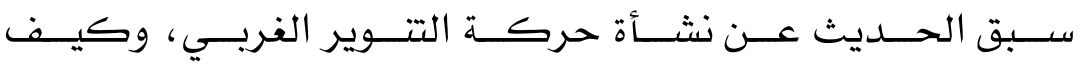
أصـبـح العقـل الفريسي يسـتبعد الـدين - النصــراني واليهـودي- مـن صـلته بالحياة.

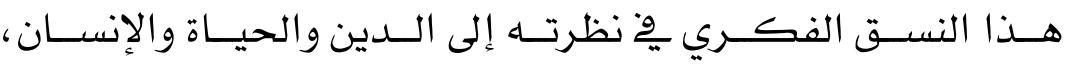

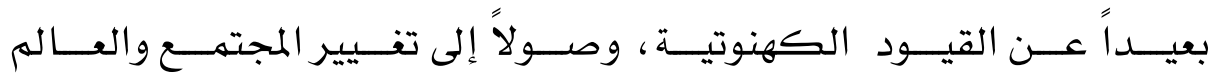

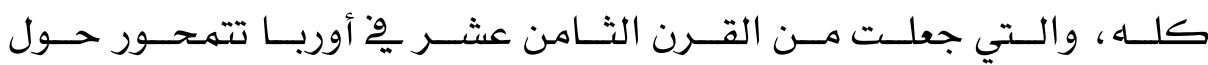

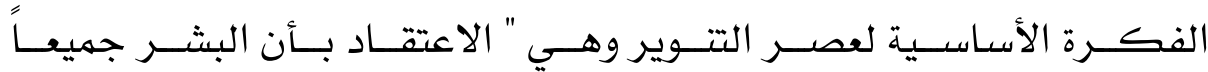

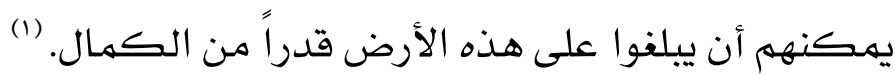

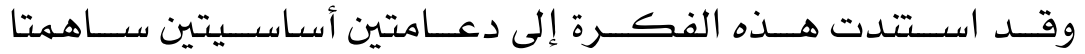

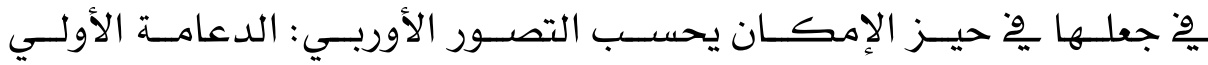
الطبيعة، والدعامة الثانية العقل.

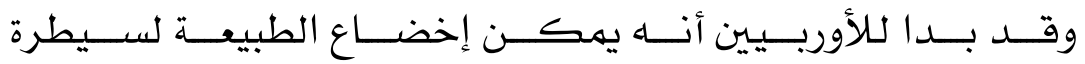

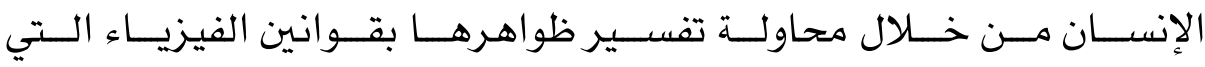

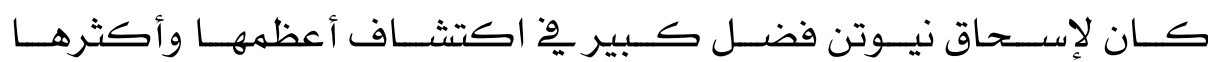

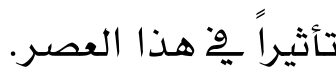

وأكـــد دعــاة التـــوير " أن العقــل ســبيلنا للنفـــاذ إلى الحقيقــة الكـامنــة وراء الظـواهر. فبــدون العقـل، أو حتـى بالعقـل بهعنــاه الخــاطئ

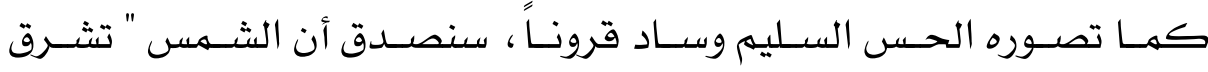

( ) في الفكر الغربي المعاصر ، د/ حسن حنفي : صـ 110

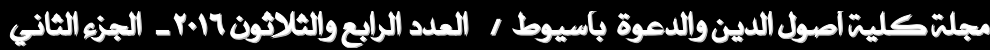




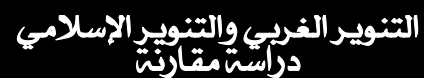

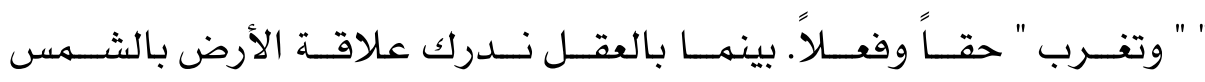
علـي وجههـا الصــحيح · وبالمثتل فإنــا إذا مـا اسـتعنـا بالعقـل وِ العلاقـات

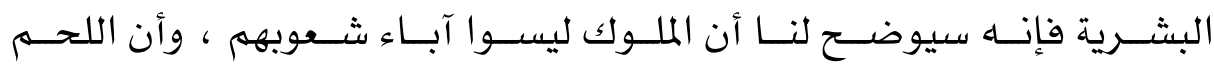

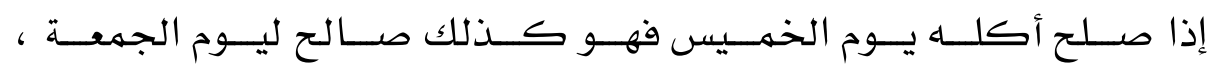

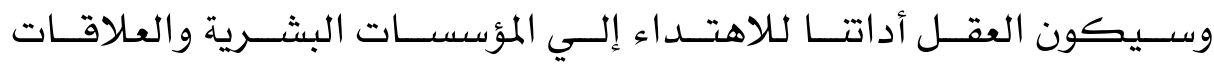

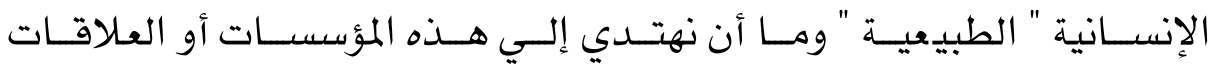

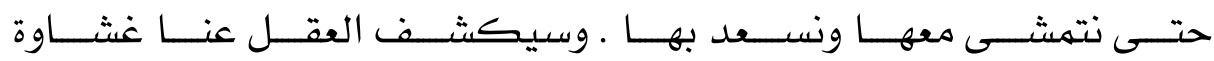

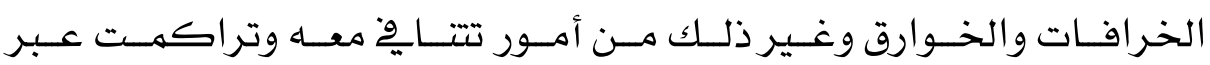

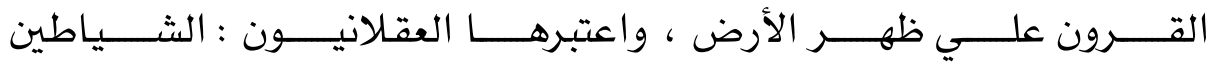
الحقيقيين . (1)

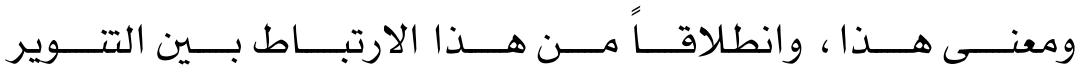

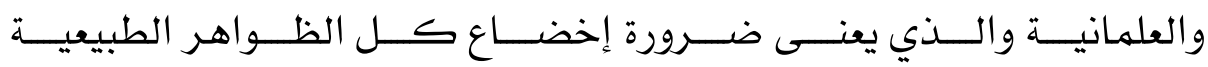
والكونيـة حتـى الـدين نفســه لسـلطان العقـل بغيـة الوصــول إلـي التفـيير الهـادف لتحقيـق كمهـال الإنســان وســعادته ، أن يـتم تـأخير كـل سـلطة أخــري وبخاصــة ســلطة الــدين الـذي تمثلــه الكنيســة ، الــتي انحصــر

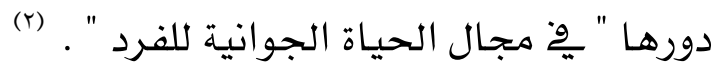
وعلــي الجملـــة كانـــت دعـــوة التــــويريين إلى تقــــيم العقــل والمصــلحة علـي كـل مـا عـداهـا ، وهــو مـا يسـتلزم ضــرورة الفصـل بـين

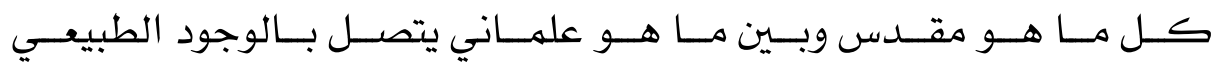

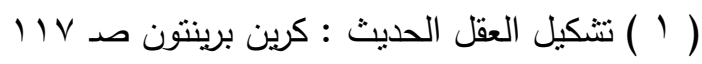

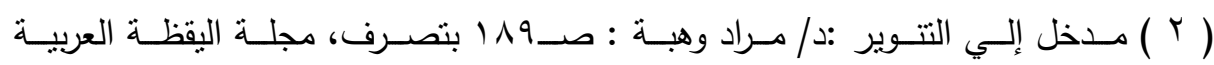
عدد مارس . 199 19 صد 197

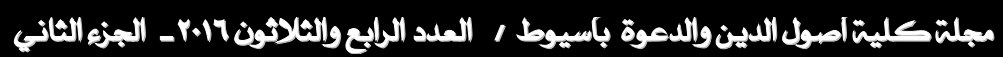




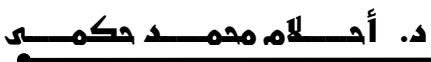

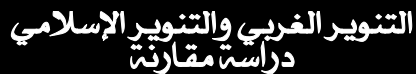

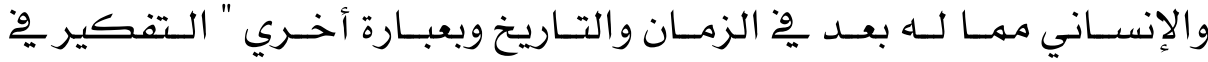
النسـبي بهـا هــو نسـبي ولـيس بهـا هـو مطلـق، وهــو مـا يعسني عـدم الوقوع

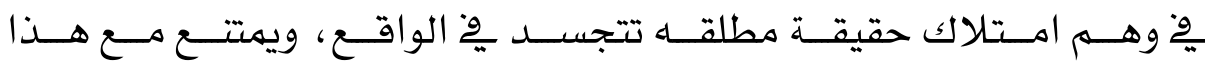

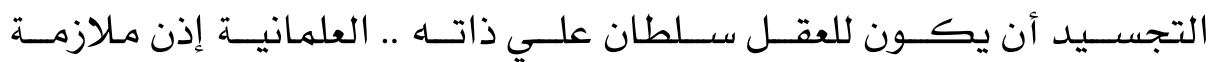
للتنوير " (1)

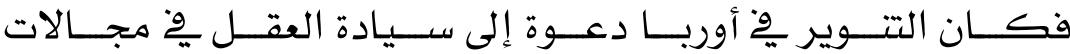

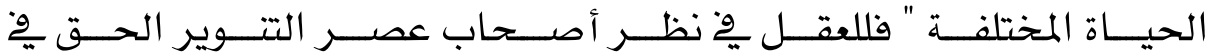
الإشــراف علـى كـل اتجاهــات الحيــاة.ووهـا فيهـا مــن سياسـية وقــانون

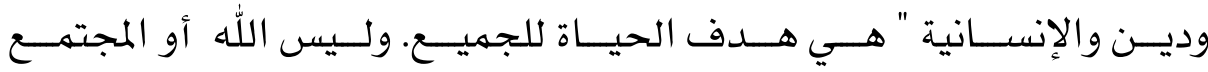
الخاص أو الدولة الخاصة ". (r) الاسله

ونـتـتج عـن هــذا وضــوح الصــلة بــين التـــوير والعلمانيــة، الــتي

تســي إلى عـزل الــدين عـن مجــالات التوجيــهـ وإحــلال العقـل محلــهـ، وطلب سيادته على أحداث الحياة واتجاهاتها. (r)

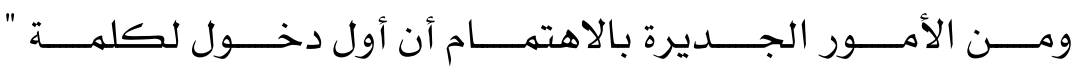

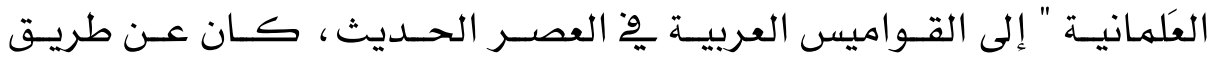

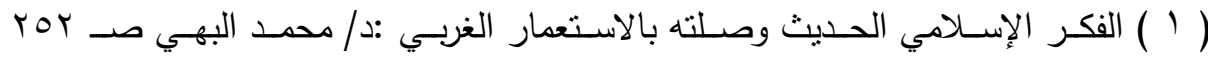

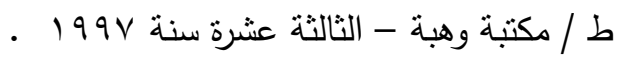

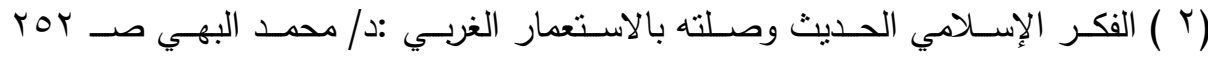

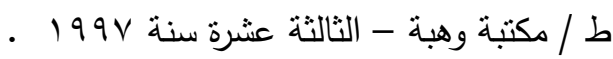

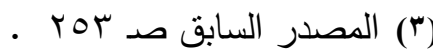




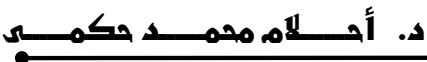

\section{التنوير الغريهي والتنتويجي الإسلاميي درأستئمقارئي}

أحسـد هــؤلاء النصــارى الـــين رحلــوا مــع الحملـة الفرنسـية وهــو "إليـاس بقطر" ، الذي رحل مع الحملة الفرنسية ،

وكــان يـدرس العاميــة المصــرية للفرنسـيـين وِّمدرســة اللغــات

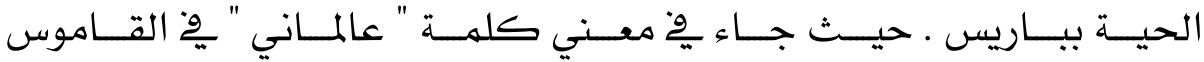

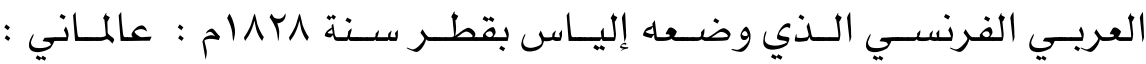

أى laique, qminest point ecclesiastiqueni religieux

الـذي لا يعطي أدني اهتهـام لكل مـا هـو لا هـوتي أو ديـني . عالمانيـة :

Secularite = etatdeseculir

${ }^{(1)}$ Seculier

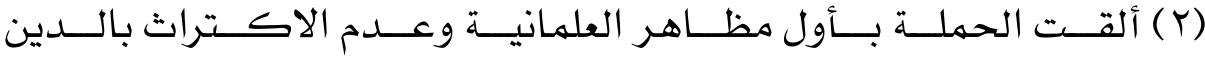

والقـيم والتقاليــد ، حيـث كــان الإطـار العـام الــذي عملـت فيــه الحملــة

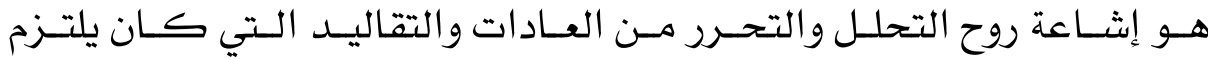

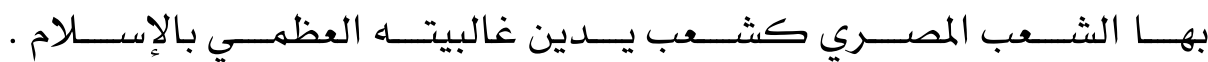
فـالجبرتي - شـاهد ذلـك العصـر - يصـف الفرنسـيـين بـأنهم " يحكهـون

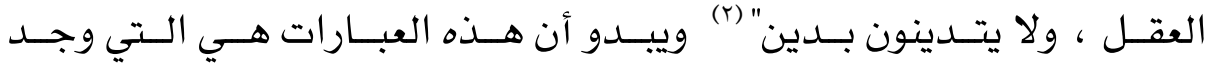

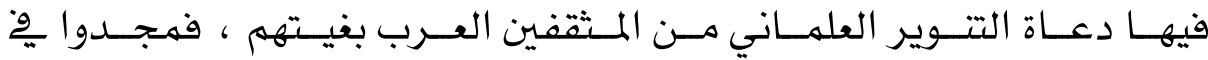
هــذه الحملـة هـذا السـعي الحثيـث نحـو التــوير الـــي تجســـت مظــاهرة

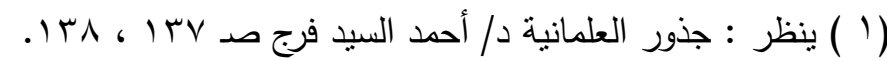

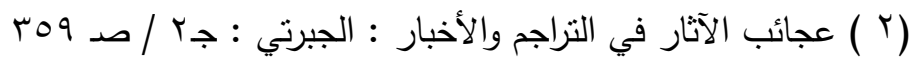




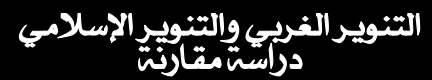

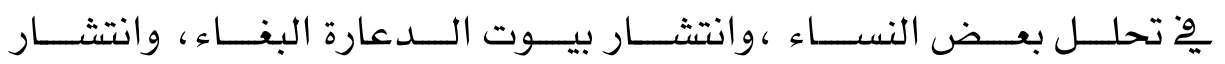

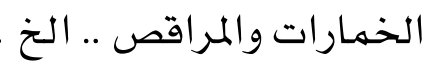

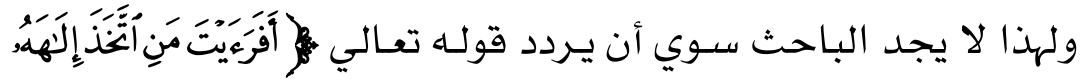

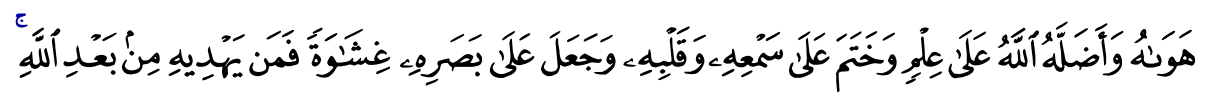
(1)

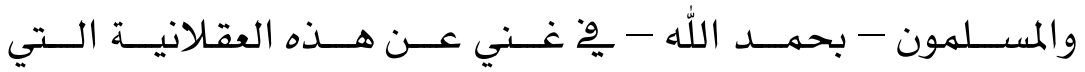

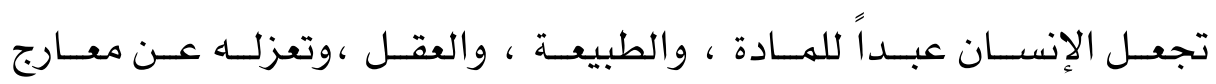

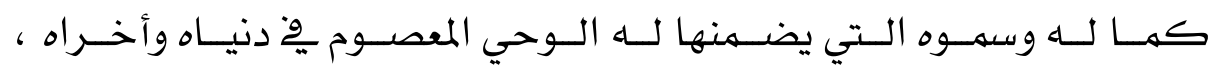

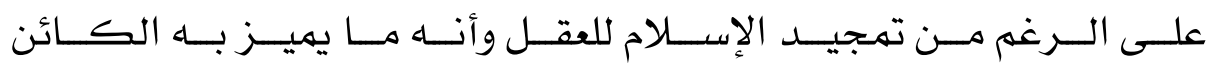

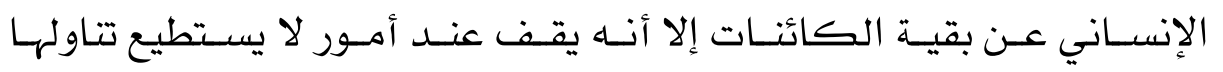

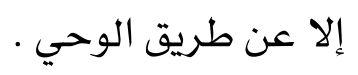

يقـول الـــكتور / مــراد هوفهـان وِّ تحليلـه لنتيجــة الصـراع بـين العلمانية والكنيسة فِّ أوريا :

" أدى التحـــرر مــن ســيطرة الكنيســـة علـى البشــر كنتيجـــة

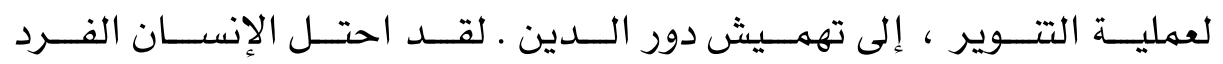

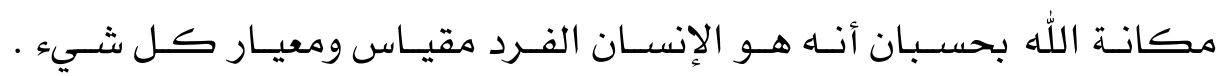

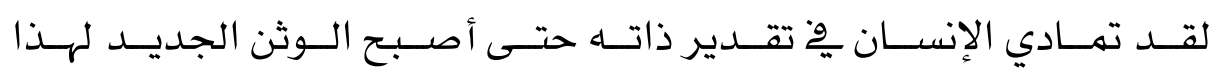
العصر ......

الآية الكريمة من سورة الجاثية : الآية رقم (Tr). 


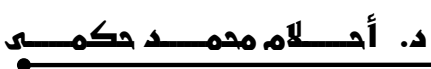

\section{التنوير الغريهي والتنتويجي الإسلاميي \\ دراستيمقارئي}

وِوْ اللحظــة الـتي أصـبـح فيهــا " الله "مجــرد إســقاط لرغبــات

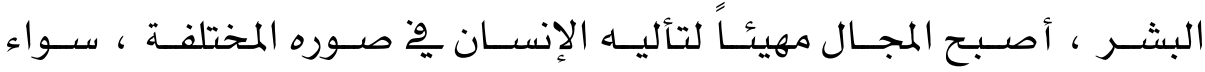

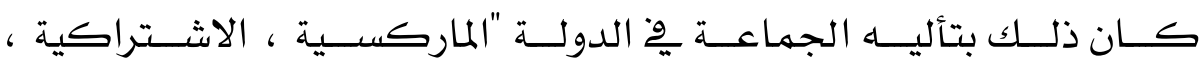

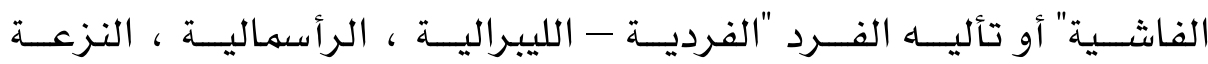

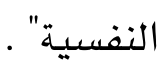

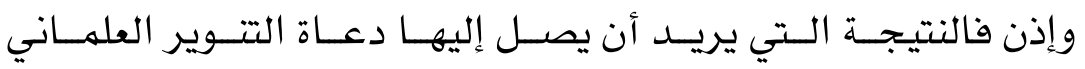

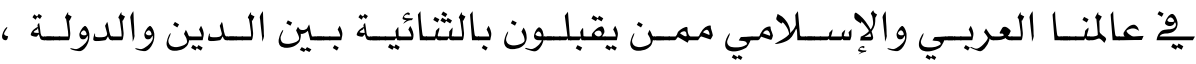

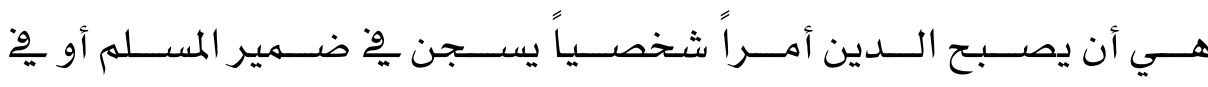

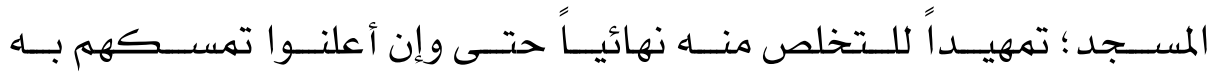

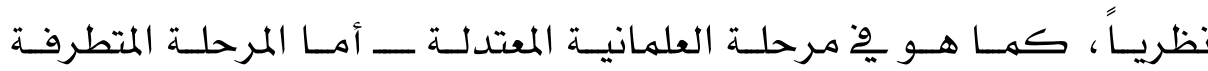

فهي تعني إبادة الدين بالكلية كها هو ِوْ الماركسية .

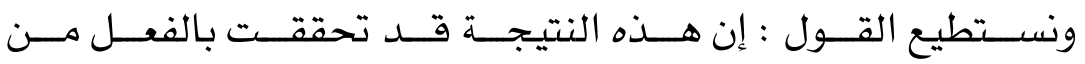

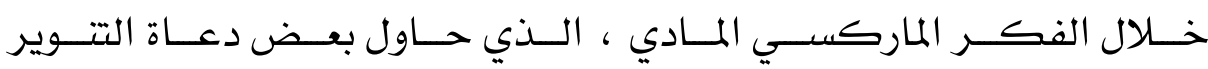

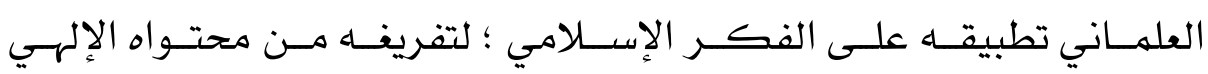

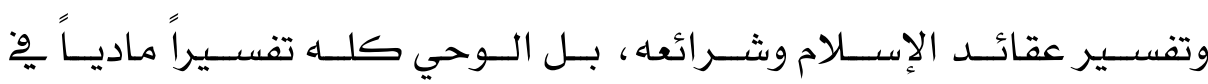

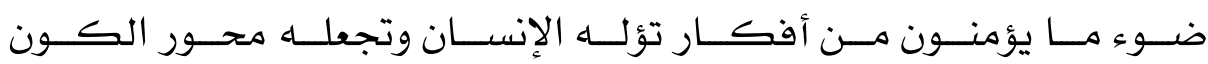
والحيـاة ، حتــى وجــنـا دعـوتهم السـافرة إلى قبــول العلمانيـة والإلحـــاد ،

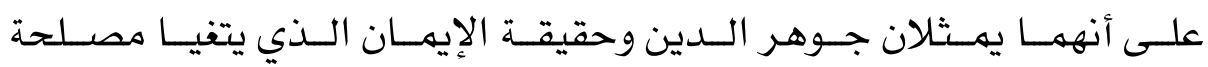

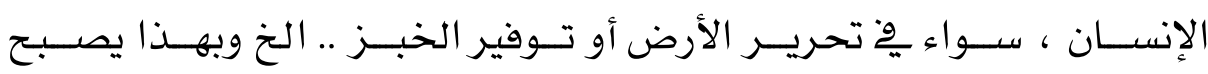

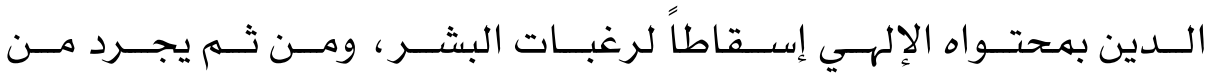

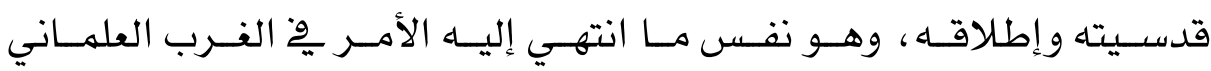
حيث سادت النزعات المادية الإلحادية. 


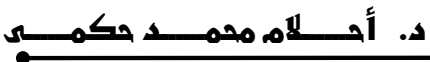

\section{التنوير الغريسي وإلتنويجي الإسلامي درأستمقارئي}

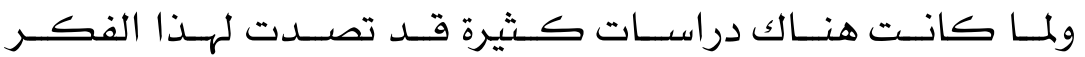

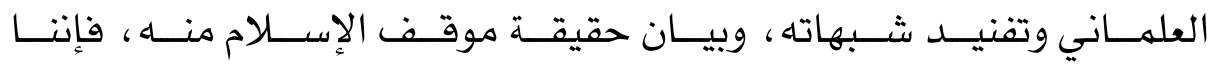
نكتقي يٌْ هذا المقام بالتركيز على النقاط الآتية: -

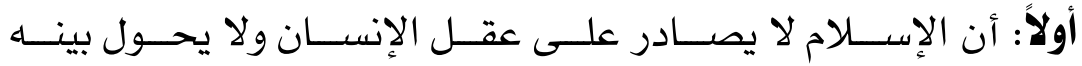

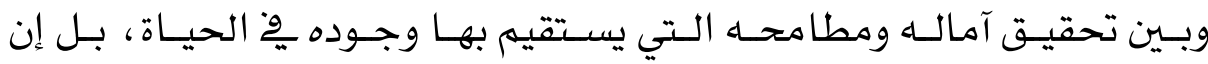

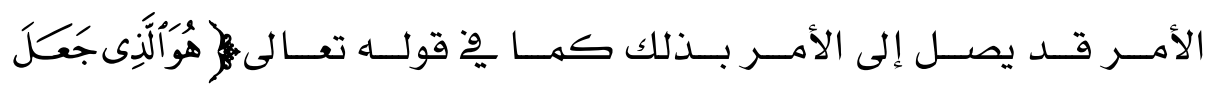

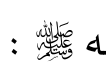

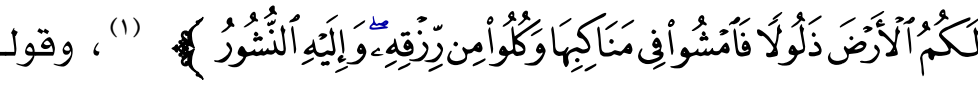

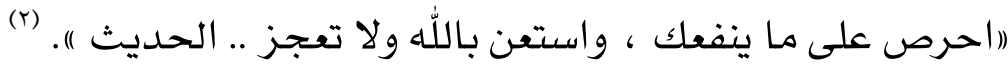

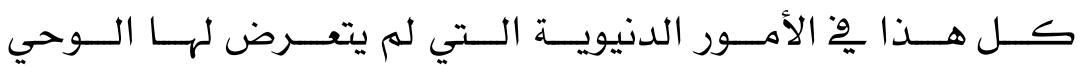

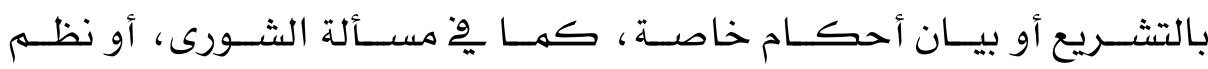

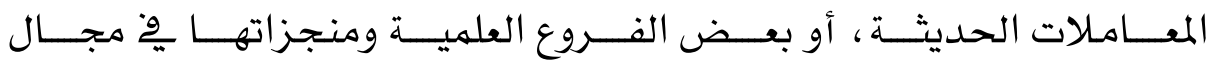

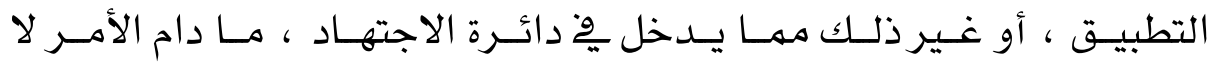

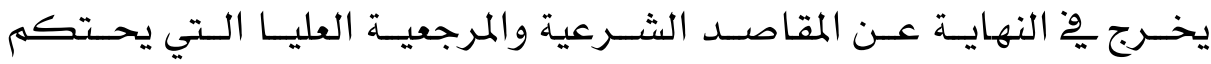

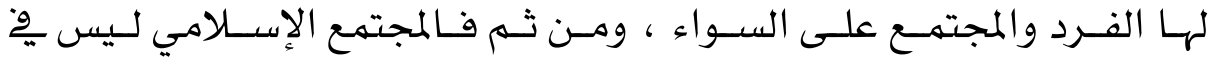

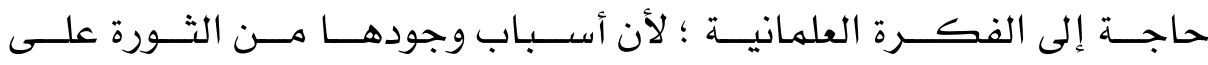
الكنيسة (r) غير موجودة وِّ الإسـلام أصلاً على نحو ما أوضحنا.

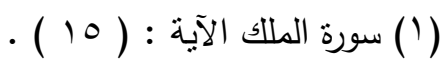

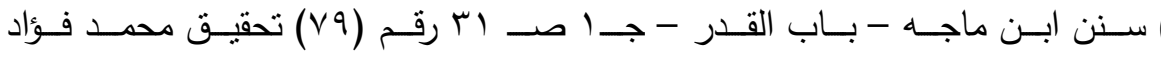

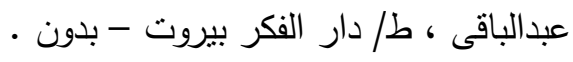

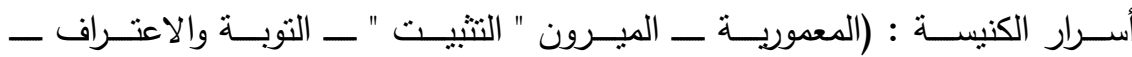

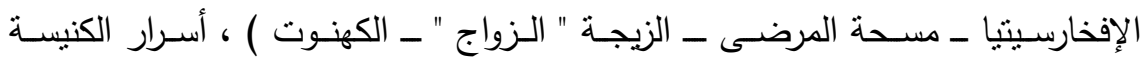

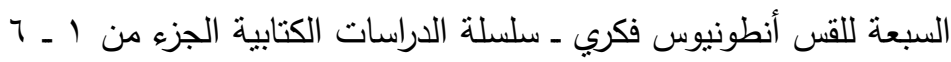




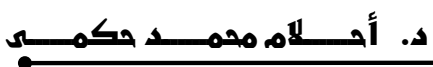

\section{التنوير الغريهي وإلتنويجي الإسلامي درأستمقارتيني}

ثانيــاً: يخلـ ط كـثير هـن العلهـانيين بــين الحكومــة الدينيـة

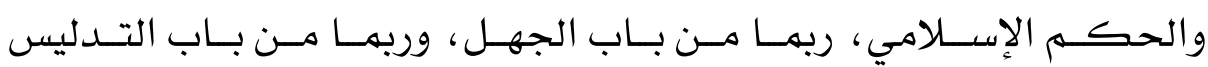

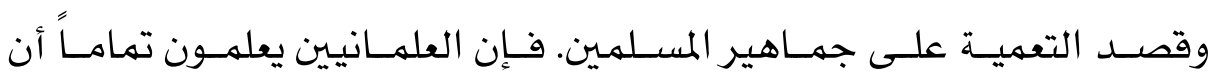

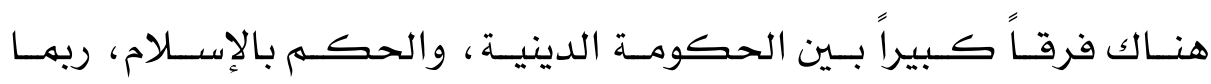
أكثر مما يعلم غيرهم.

إن جهـلـل التـــويريين العــرب بالإســـلام مــن ناحيــة ، وافتتـــانهم

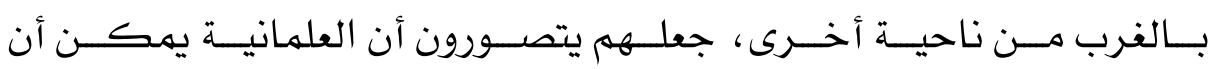

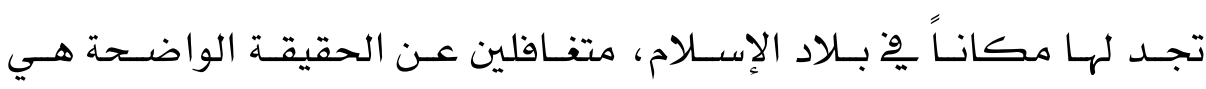

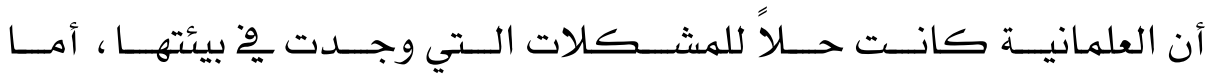

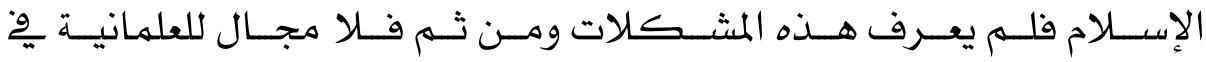

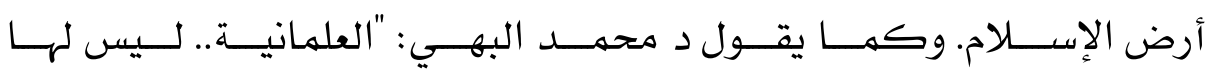

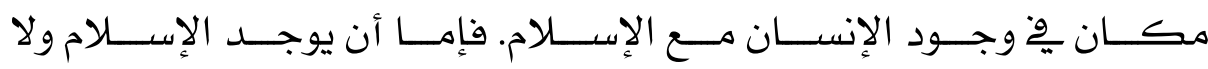

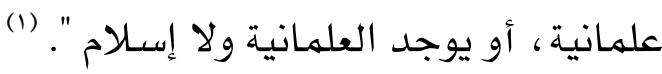

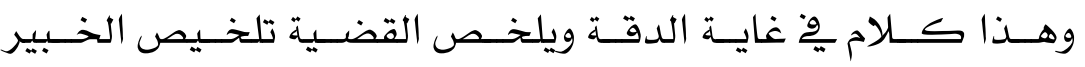

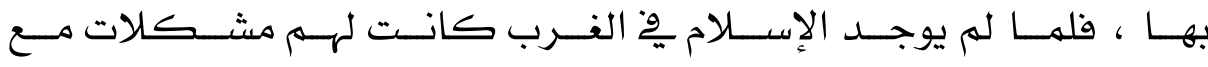
العقل والعلم والحرية والمساواة والتسامح .. الخ .

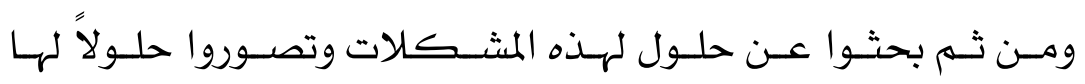

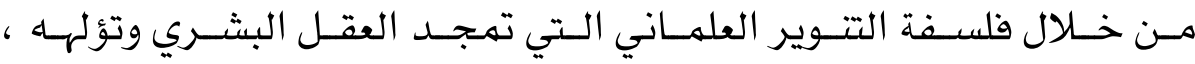

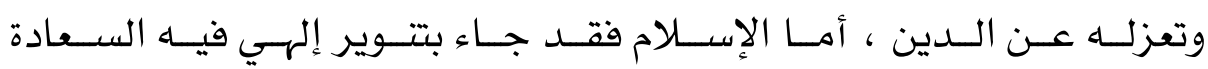

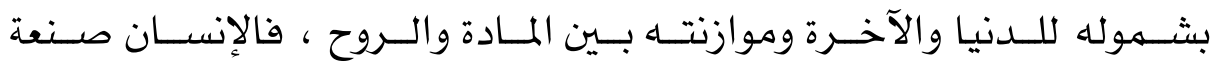

$$
\text { (1) الإسلام والعلمانية ـ د / البهي - صـ } 10 \text { بتصرف يسير . }
$$




\section{التنوير الغريج والتنوبير الإسلامي \\ دراستئمقارنيّي}

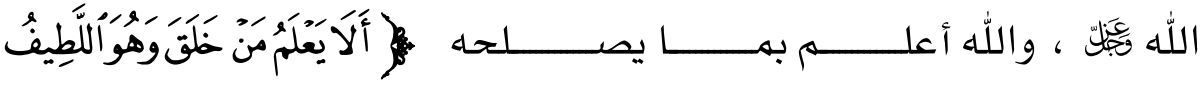

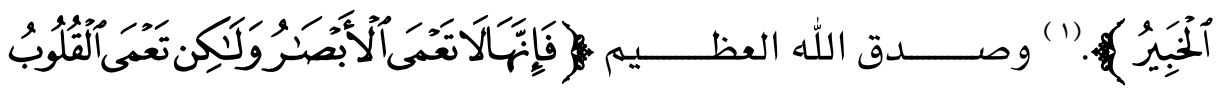

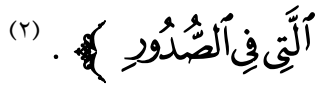

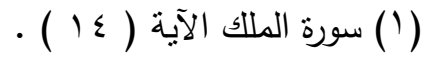

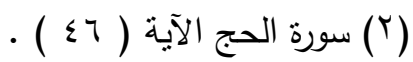




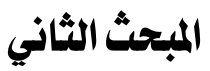

\section{دعاة التنوير الغربي في البيئة الإسلامية}

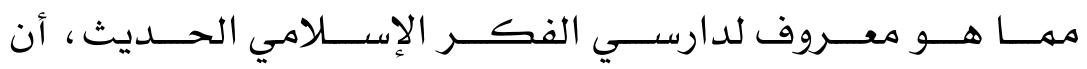

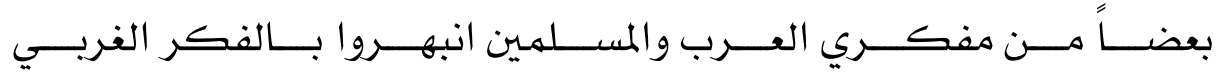

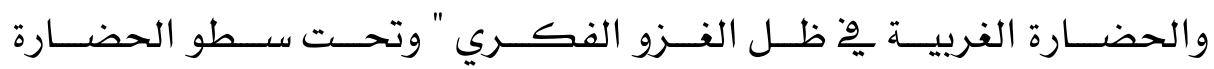

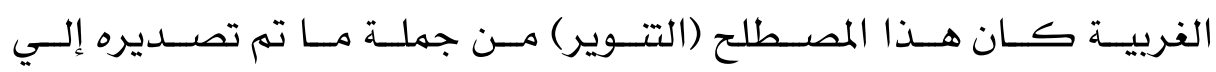

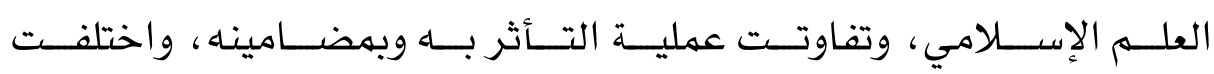

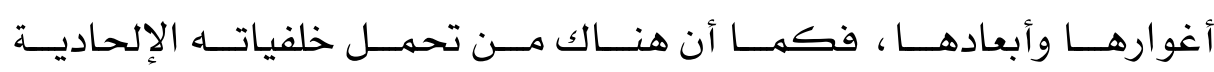

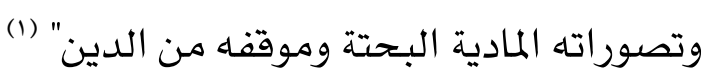

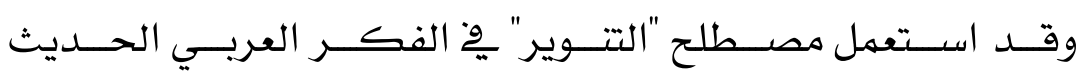

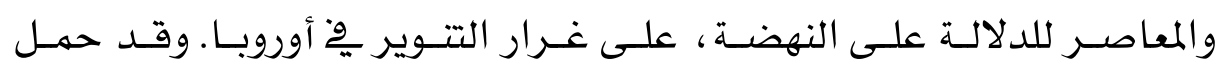

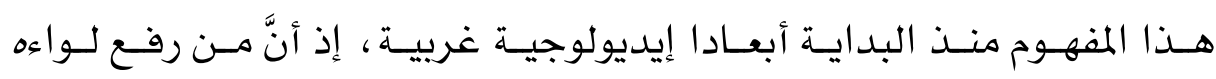

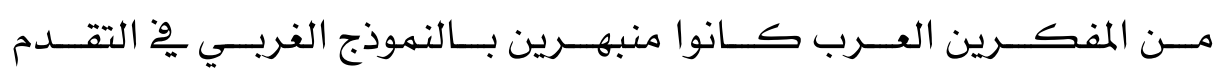

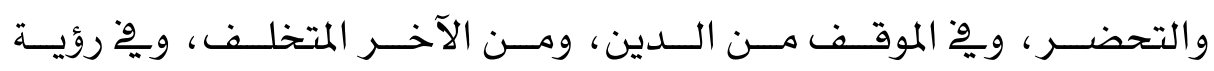
الوجود والإنسان والحياة والمصير.

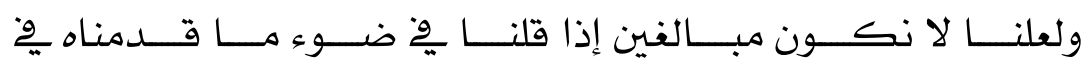

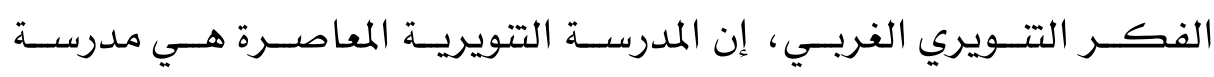

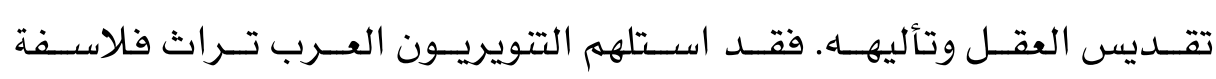

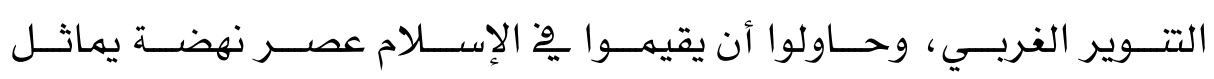

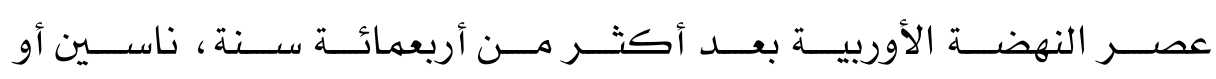

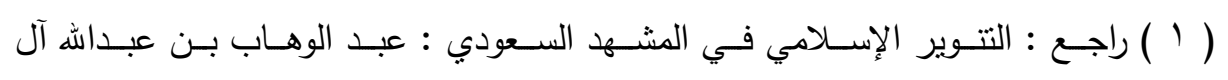

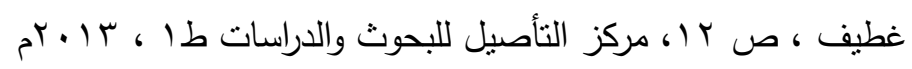




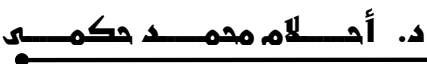

\section{التنوير الغريهي والتنتويجي الأسلاميي دراستيمقارئي}

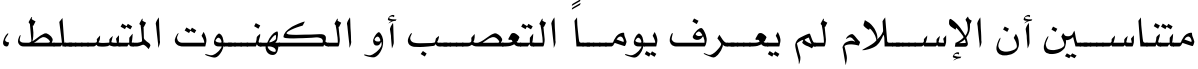

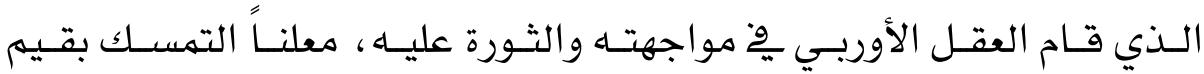

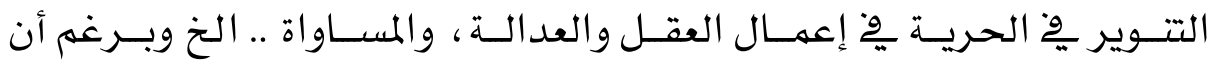

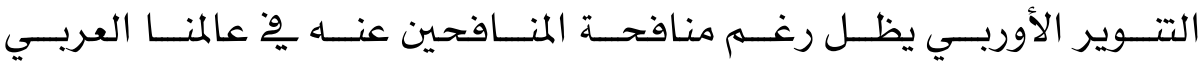

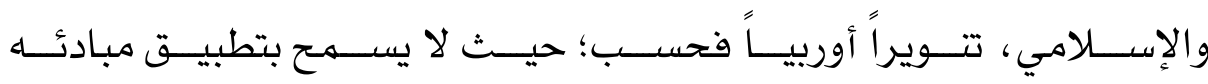

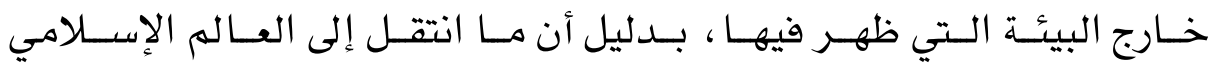

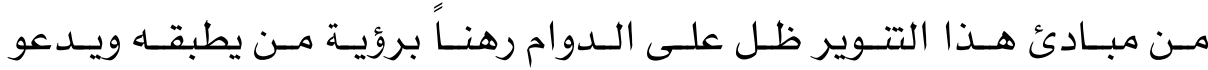

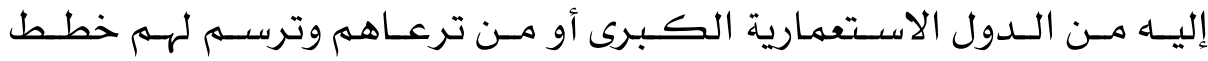
العمل داخل المجتمعات العربية والإسـلامية.

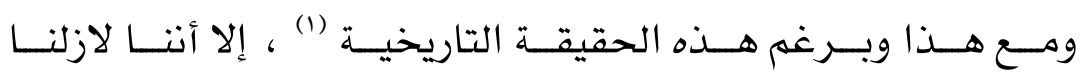

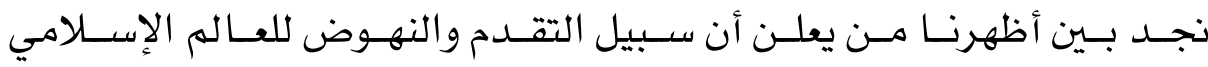

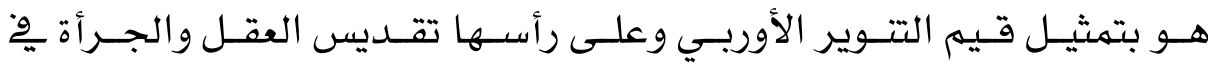

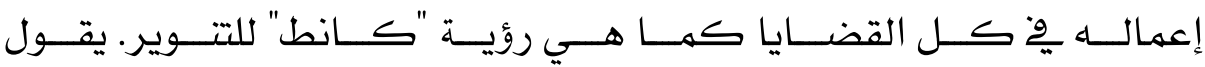

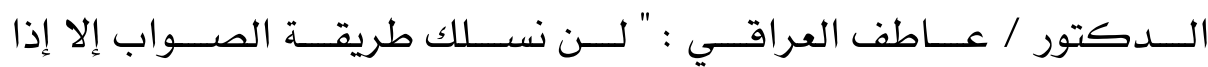

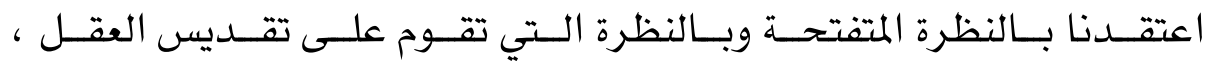

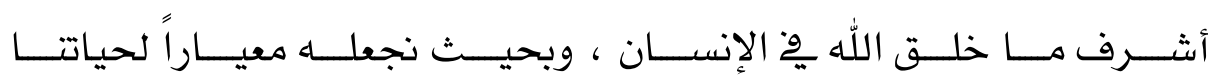
الفكريـة والاجتهاعيـة ، وحتـى يصـبـح عالمنــا العربـي وكأنـه قطعـة مـن أوربا التي تعد معبرة عن السلوك الحضـاري المتطور .."(r)

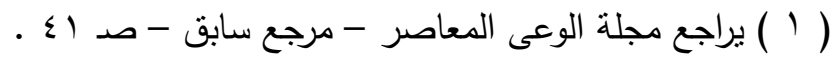

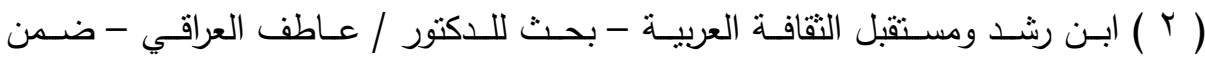

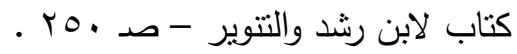




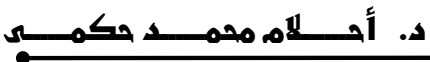

\section{التنوير الغريسي وإلتنويجي الإسلامي درأستئمقارئي}

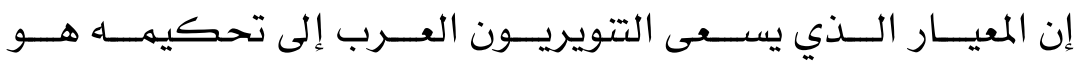

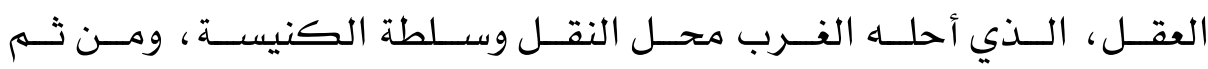

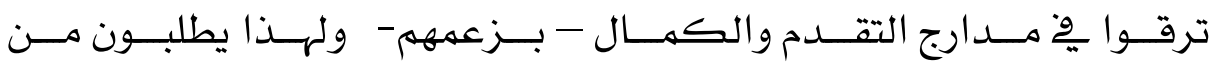

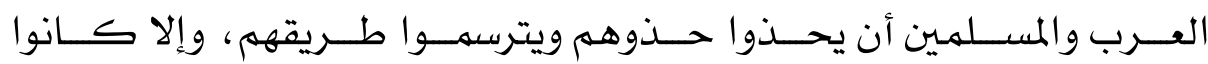
ظلامـيـين رجعـيين مــتخلفين عـن ركــب الحضـــارة والمدنيـة والتتــوير

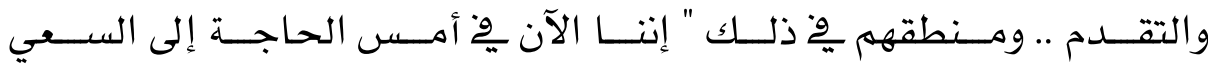

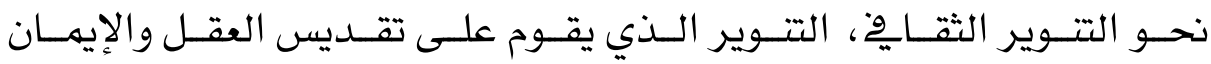

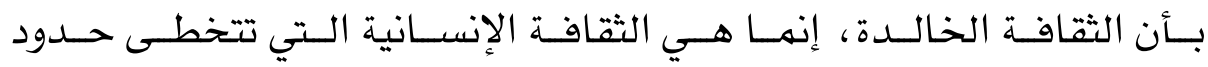

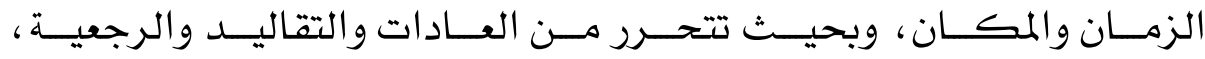

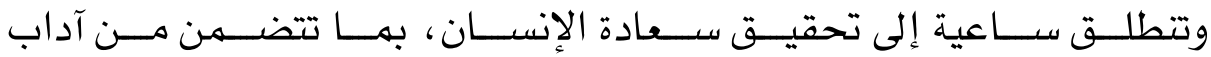
وعلـوم وفــون ســامية رفيعـة ، وعـن طريـق التــوير نســطيع إرســاء نظــام

$$
\text { ثقايْ عربي جديد. }
$$

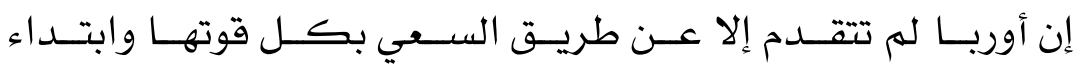

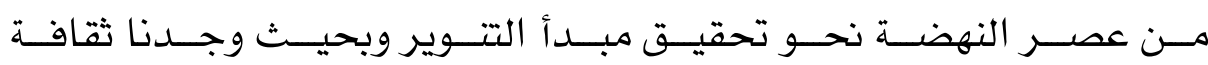

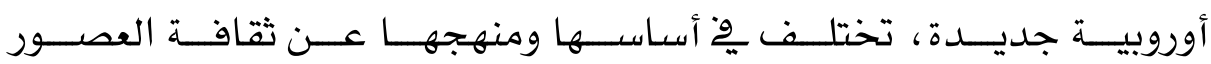
(1) " الوسطى. (1)

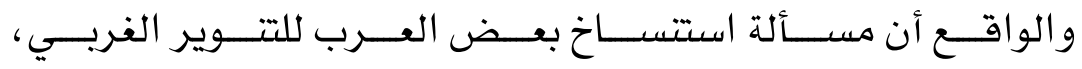

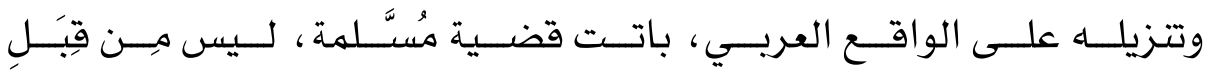

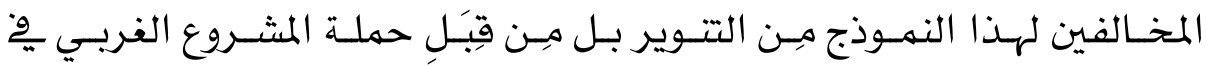

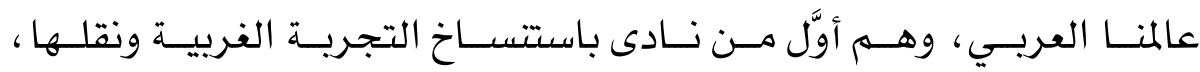

(1 ) العقل والتتوير : عاطف العراقي صد ع ا ـ

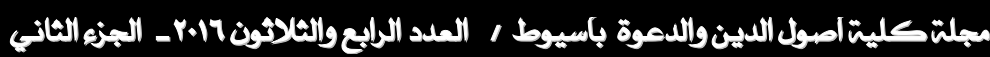


باعتبارهــا القنطــرة الضــرورية لعبـور الفجــوة بينتــا وبـيـن التقـدم بجميـع أبعاده. وهذا الأمر يؤكده غير واحد من دعاة "التتوير" عندنا.

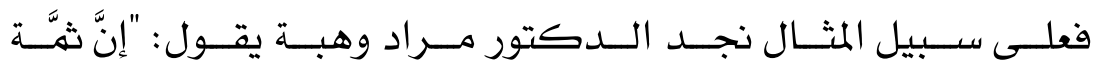

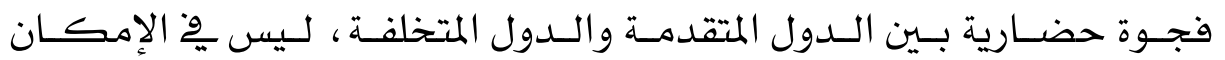

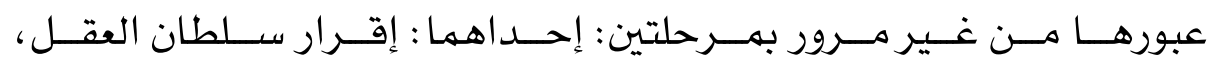

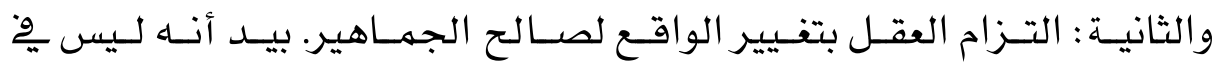

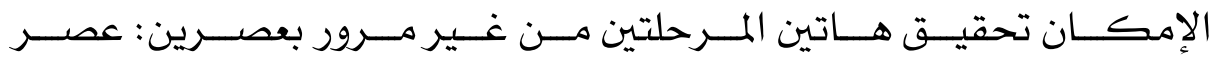
الإصــلاح الـديني الـذي حـرر العقـل مـن السـلطة الدينيـة، وعصــر التـــير

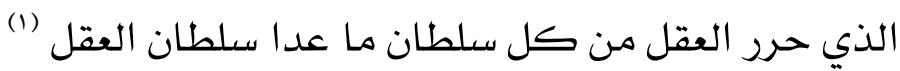

كهــا أكــد الــدكتور عـاطف العراقـي - المـتحمس للعقلانيـةنفـس الفـكـرة، حـــن قـال: "عـن طريـق التــوير نســطيع إرســاء نظــام

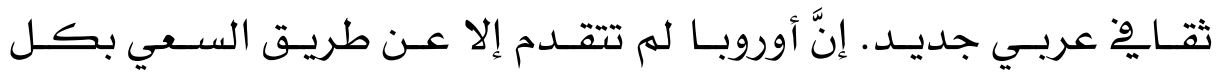

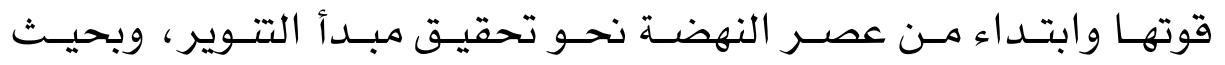

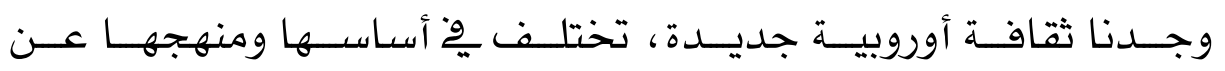
ثقافة العصور الوسطى" (r) ثاجل

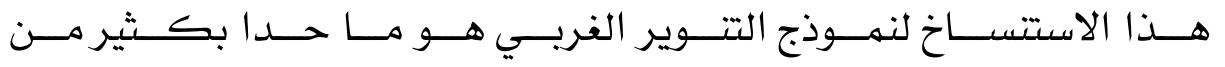

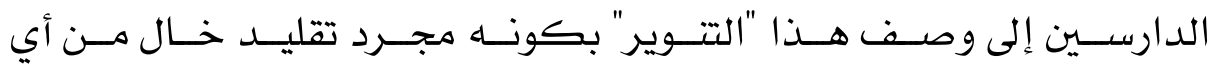

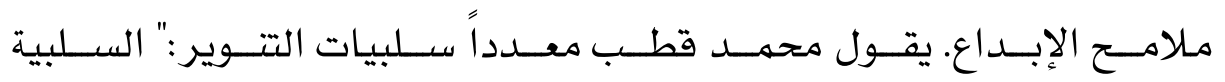

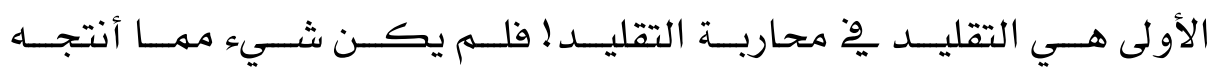

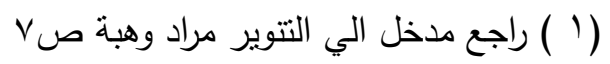

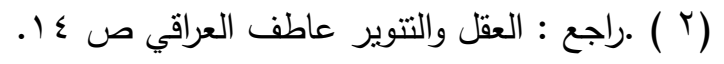




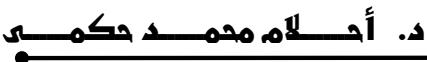

\section{التنوير الغرجية والتنويجي الأسلامي}

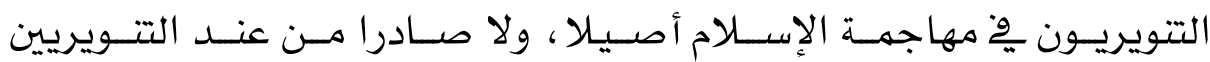

(1) أنفسهمه .

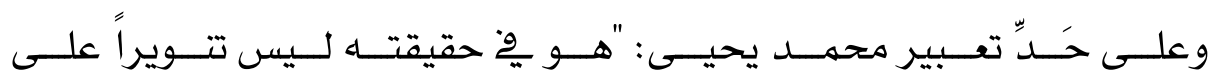

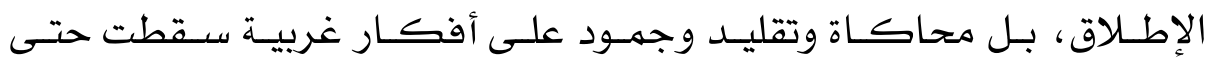

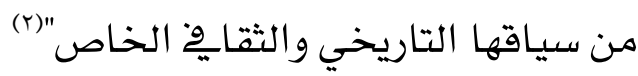

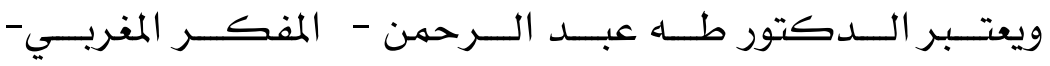

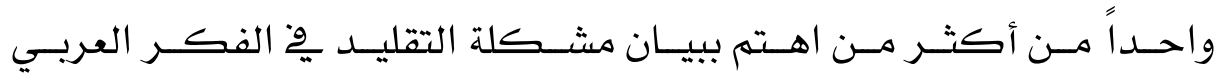

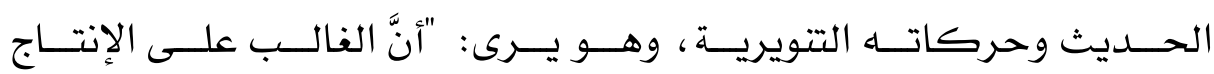

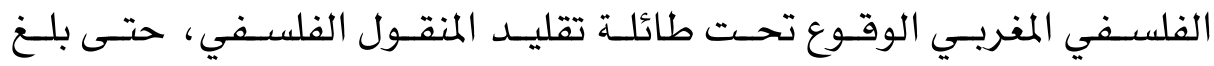

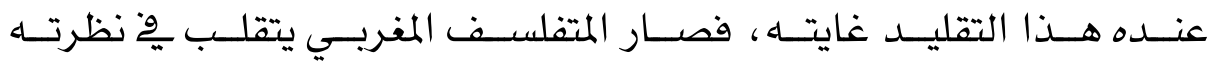
الفلسفية تقلب هذا المنقول من غير داع سوى طلب التقليد".

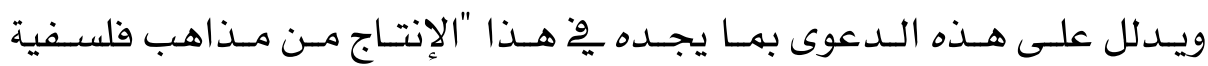

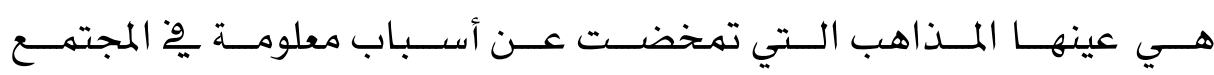

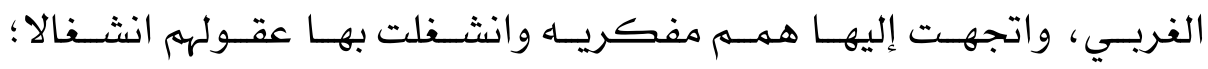

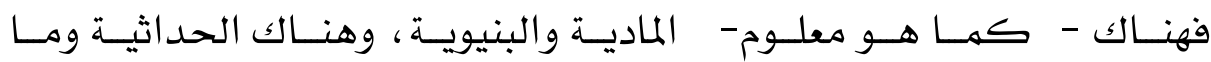

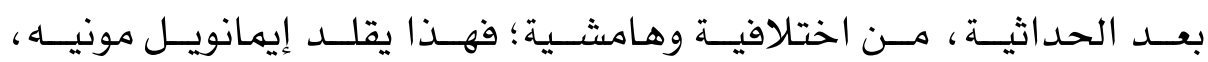

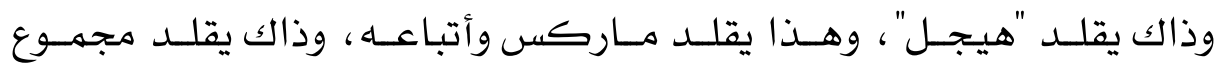

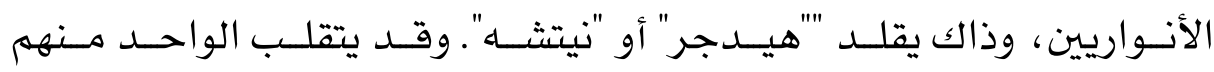

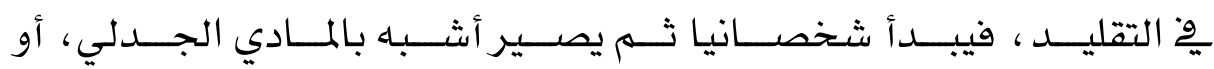

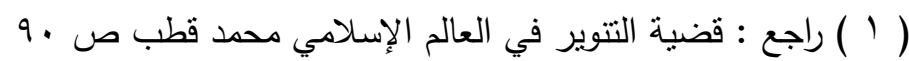

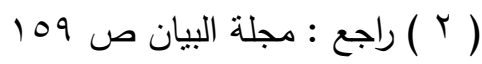




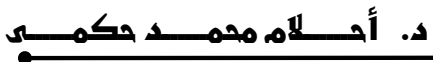

\section{التنوير الغريسي وإلتنويجي الإسلامي درأستئمقارئي}

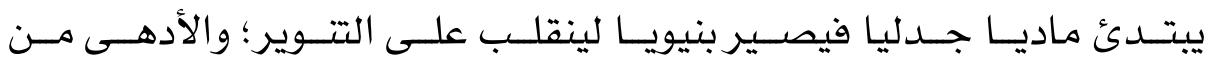

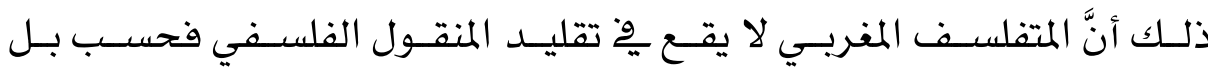

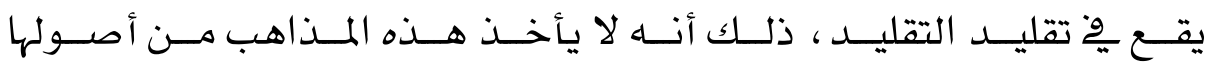

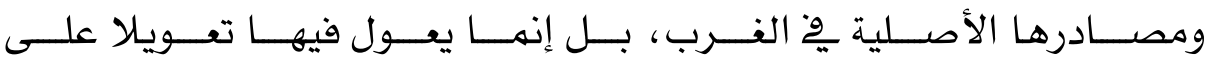

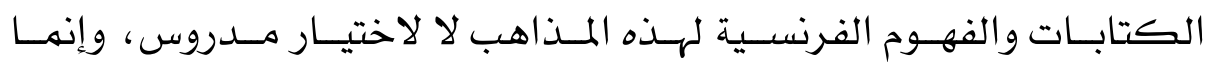

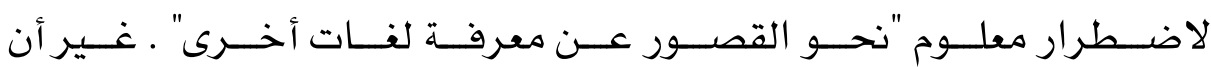

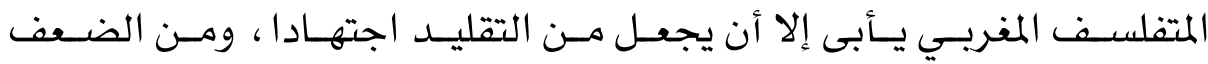

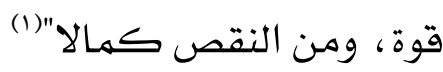

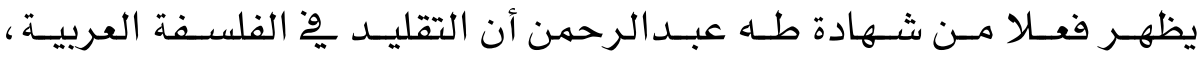

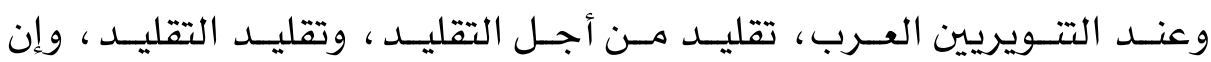

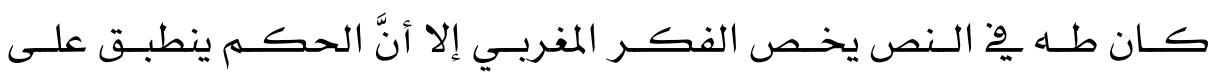

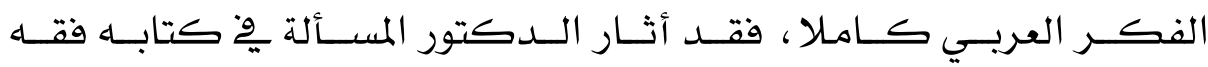
الفلسفة : الفلسفة والترجمة" (r)

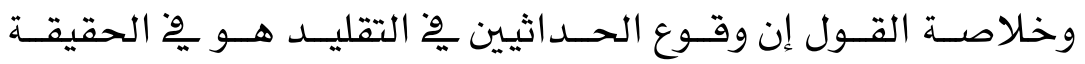

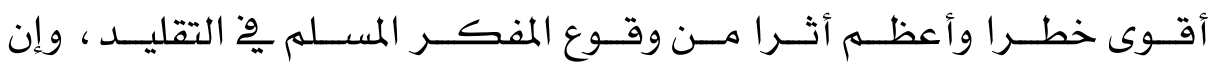

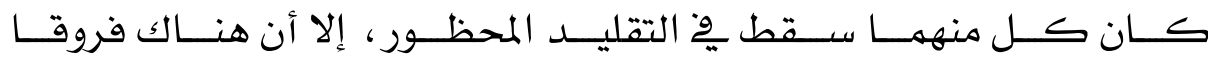

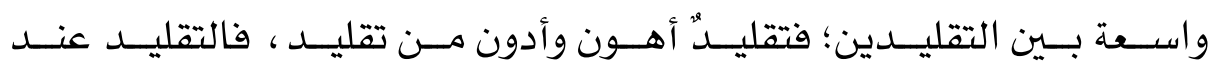

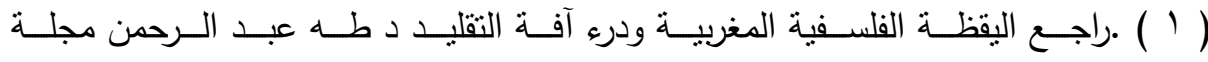

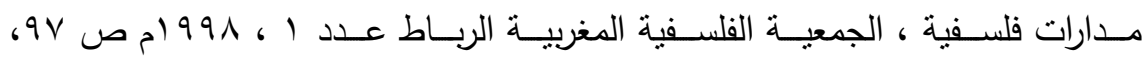

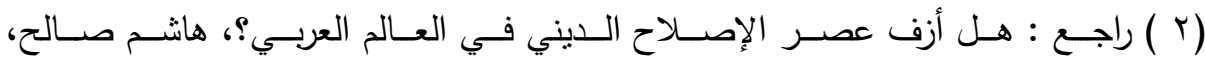

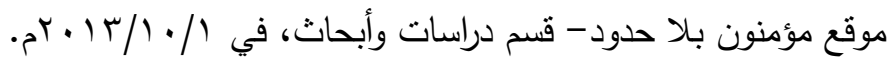




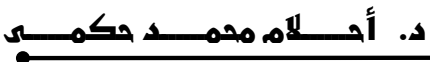

\section{التنوير الغريسي وإلتنويجي الإسلامي درأستمقارئي}

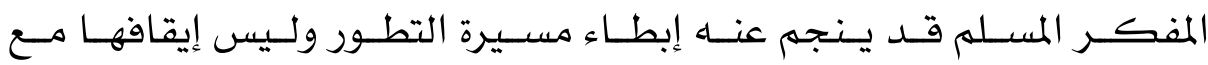

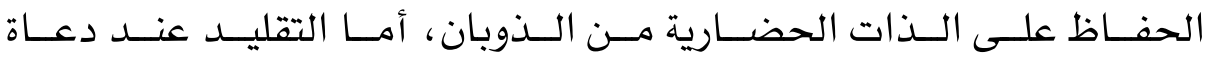

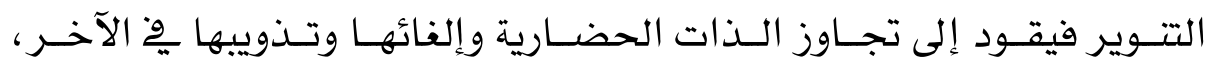

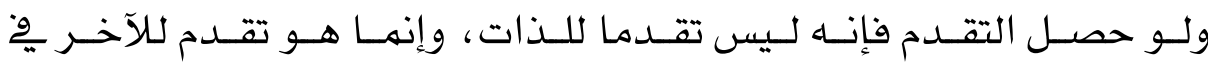
انتصاره على الذات غزوا وهحوا ، تفريبا وتغييبا.

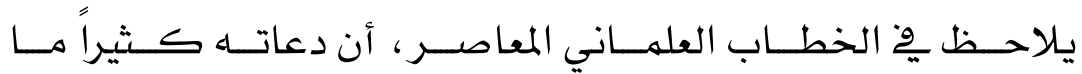
يريطــون بـين التــوير والإبــاع، وفوضــي حريـة التعـبير. وإذا كانـت هـــهـ

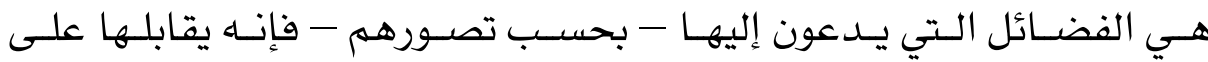

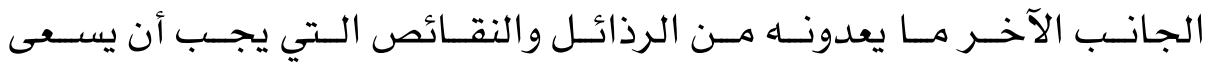

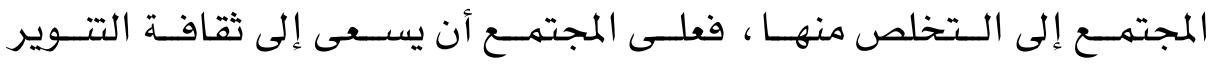

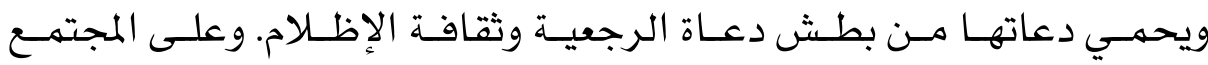

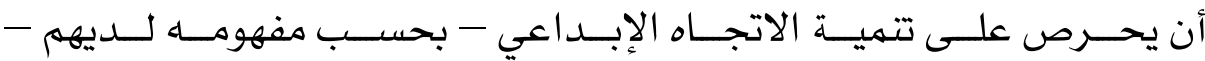

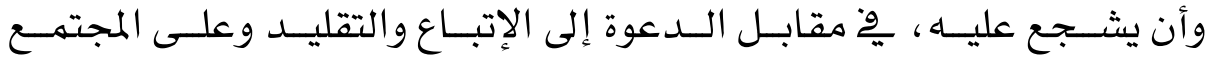

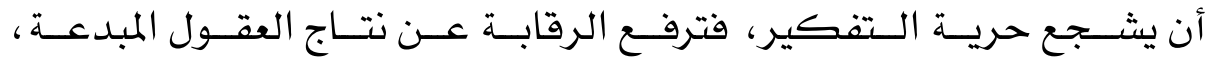

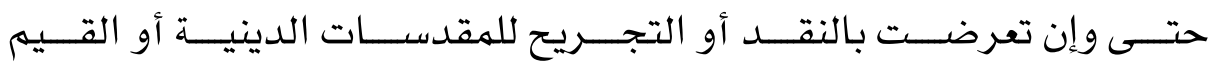

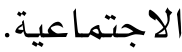

ونســطيع القــول إن التــويريين المعاصــرين، يــرون يِّ الأفكــــار

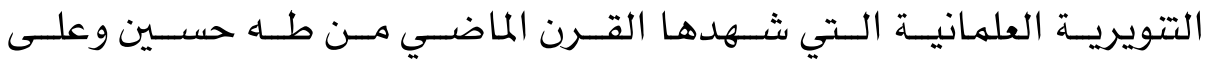

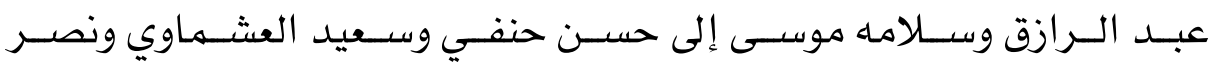

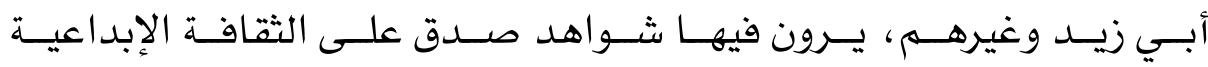

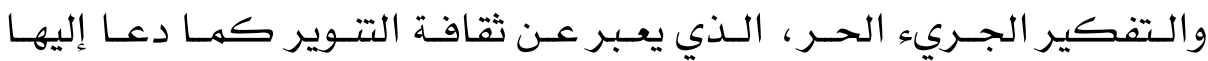

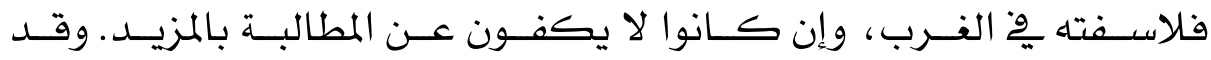




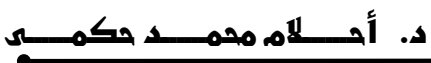

\section{التنوير الغريهي والتنيويجي الإسلامي دراستيمقارئي}

عرضــا مـن قبـل لنهـاذج مـن هـــه الأفكــار التتويريـة ، الـتي تعـبر عـن الإبداع العلماني المتجاوز للقيم الدينية والتراثية للأمة الإسـلامية.

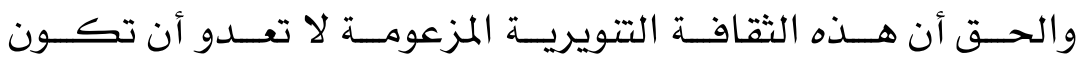

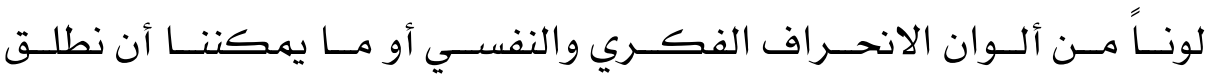

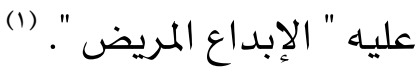

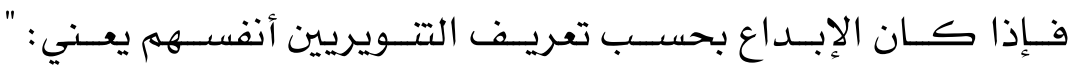

قدرة العقل على تكوين علاقات جديدة من أجل تغيير الواقع ". (r)

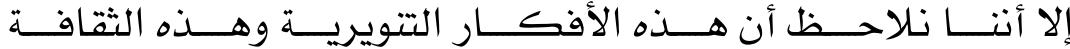
الإبداعيـة ، لا يكــاد يعـرف منهــا إلا جانـب الجـــة ومخالفــة المــألوف مـن

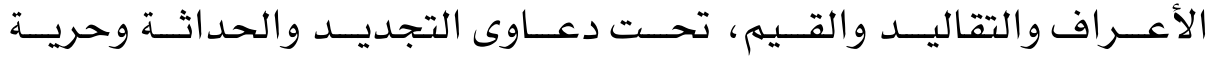

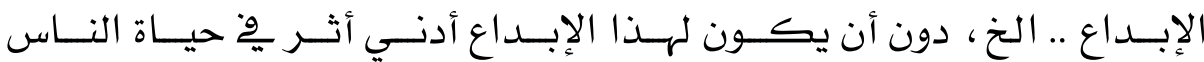

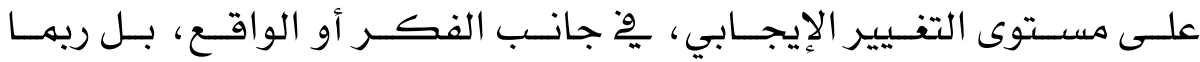

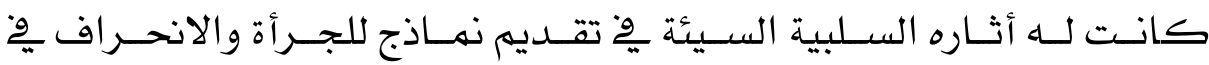

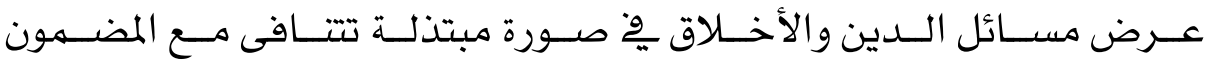

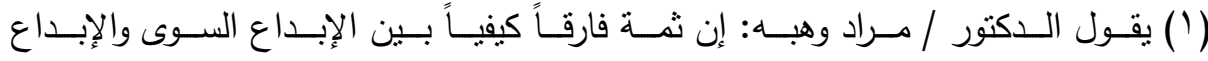

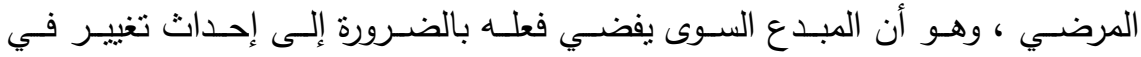

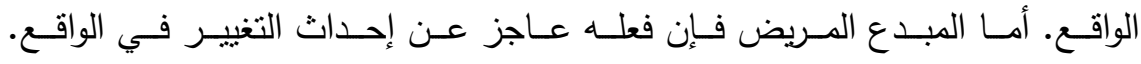

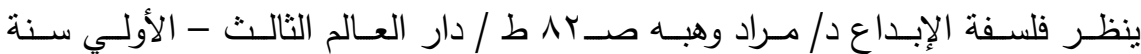
.01997

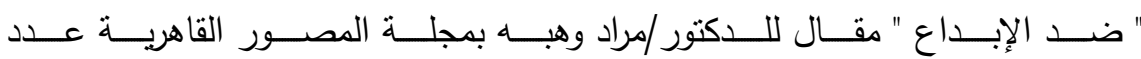

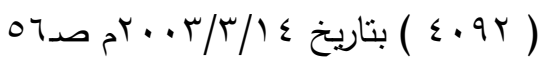




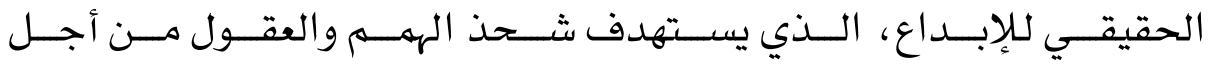
تحقيق " غاية " معينة هي رقي الإنسان وكماله مادياً وروحياً.

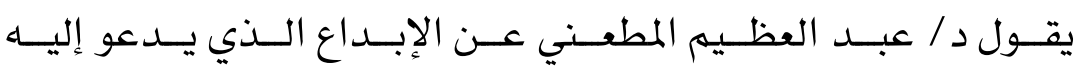

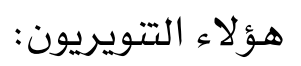

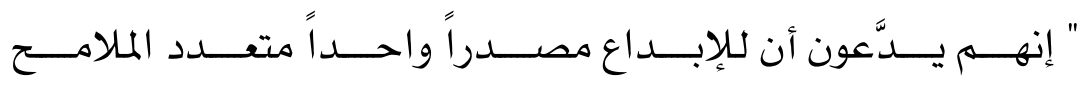

والقســـات، إنــه : الانحــراف والتمــرد علـى كـل مــوروث ومــألوف: تهــرد تكن مبدعاًٌ انحرف تكن أدبياً عملاقاً.

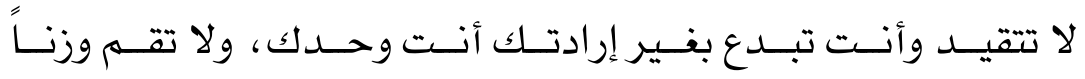

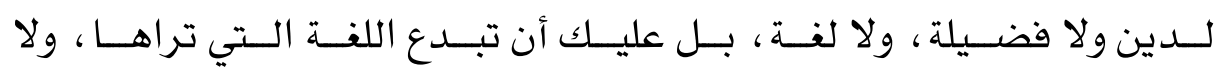

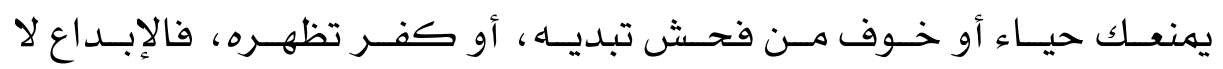

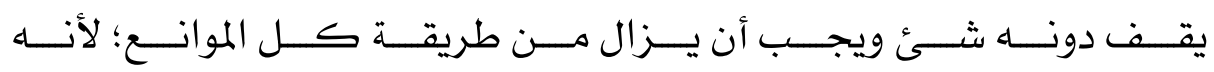

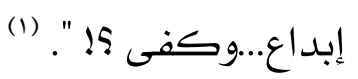

\section{الربط بين الإلحاد والتنوير عند الدكتور/ عبد الرحمن بلدوي:}

ربـط د عبــد الـرحمن بــدوي بــين حركــة الإلحــاد الـتي ظهـرت

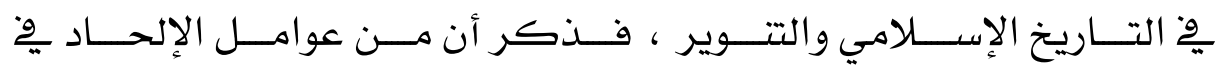

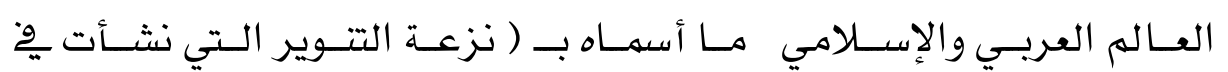

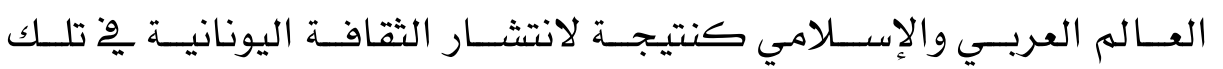

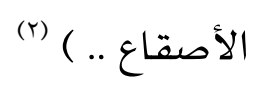

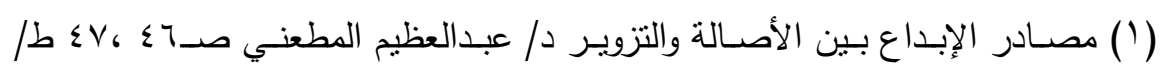

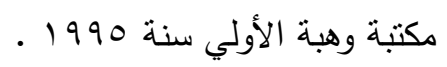

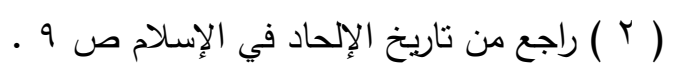




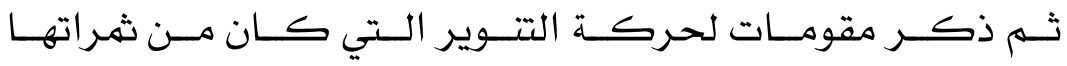

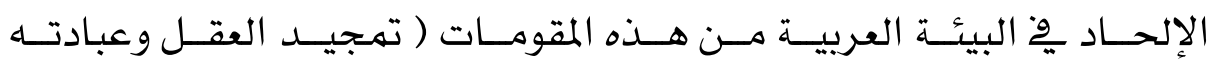
بحسـبـانه الحـاكم الأول والأخـير .. وفكـــرة التقـدم المســتهر للإنســانية

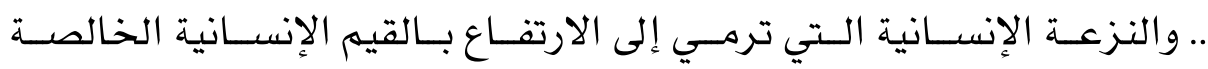

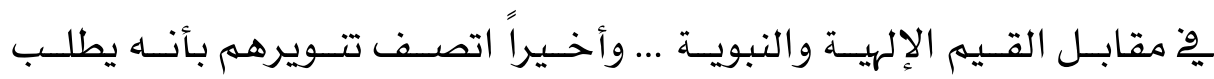

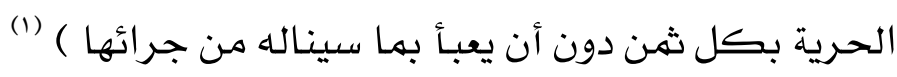

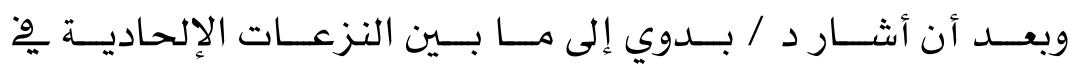

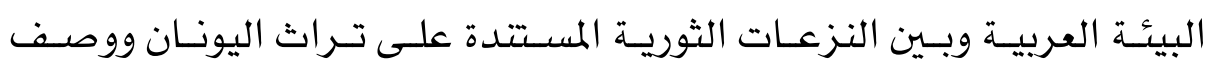

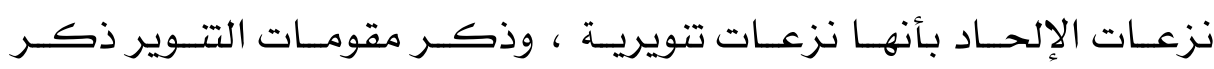

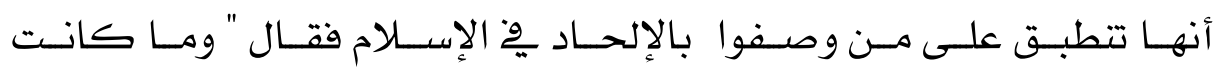

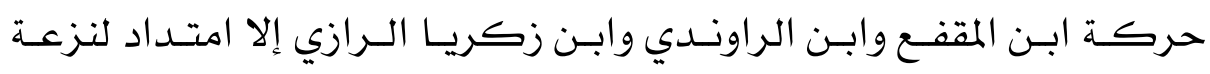

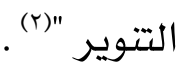

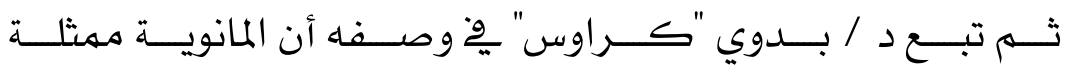

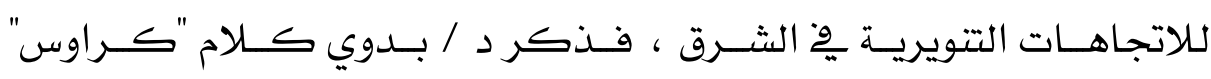

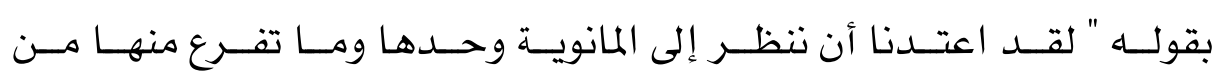

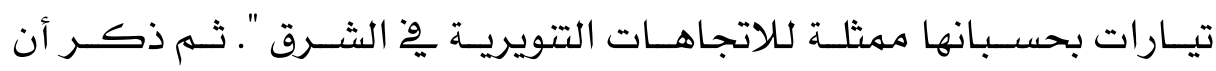

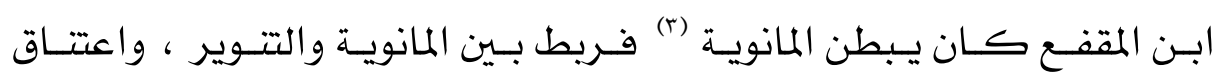

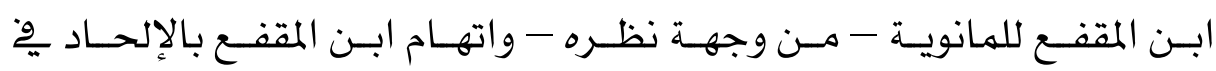

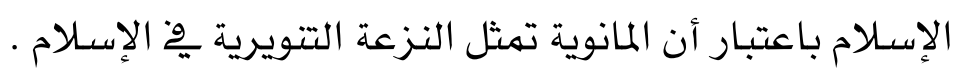

$$
\begin{aligned}
& \text { ( 1 ) المصدر السابق ص } 9 \text { - 11 (1) . }
\end{aligned}
$$

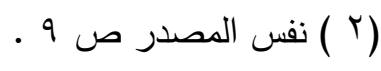

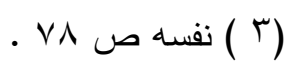




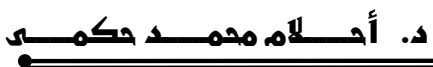

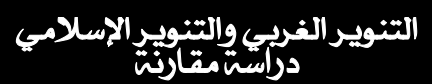

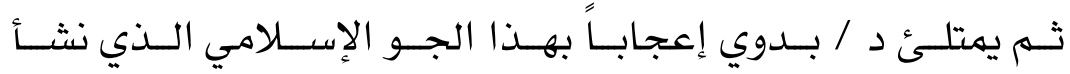

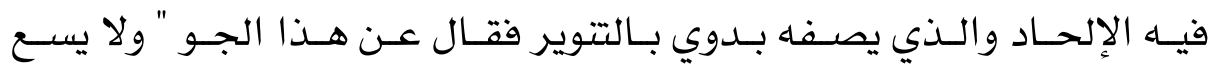

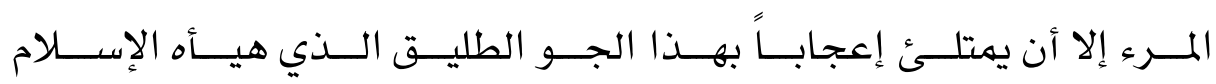

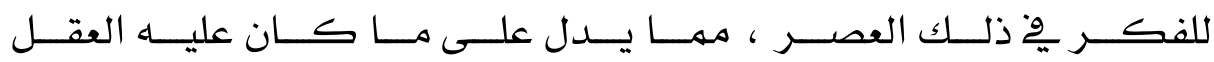
الإسـلامي يٌْ ذلك العصر من خصب ونضوج " (1)

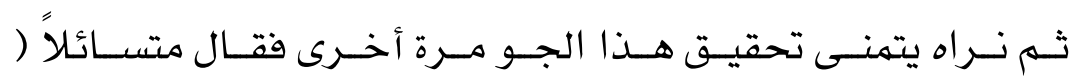

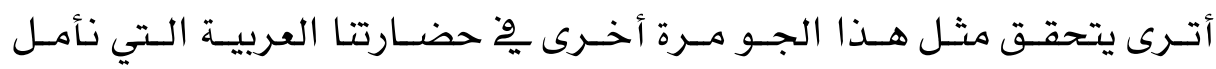
مُ والــنـي نهــف إليـهـ أن د / بــدوي يـربط بــين الإلحــاد والتــوير

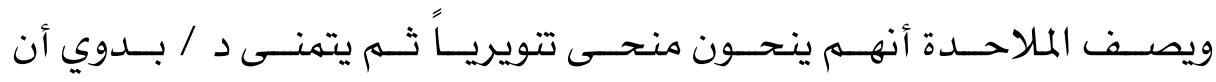
يعود هذا الجو لظهور هذا النوع من التقكير بِّ البيئة الإسـلامية. وبعبــارة مــوجزة يســى التتويريــون العــرب إلى إحــلال الثقافــة

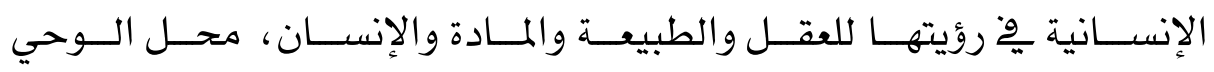

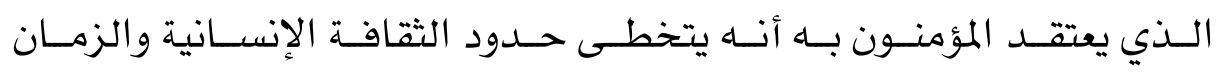
والمكان.

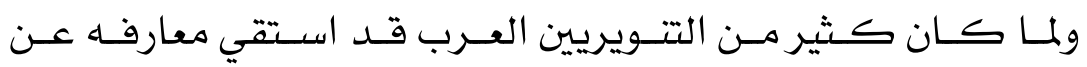

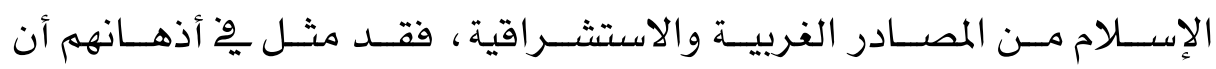

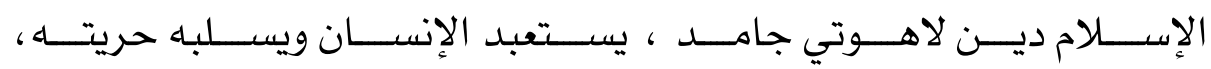

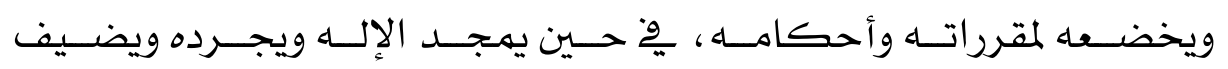

$$
\begin{aligned}
& \text { (1 ) من تاريخ الإلحاد د / بدوي ص r بهץ . }
\end{aligned}
$$

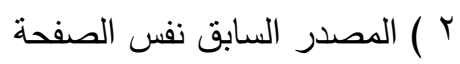




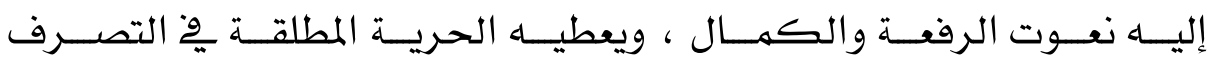

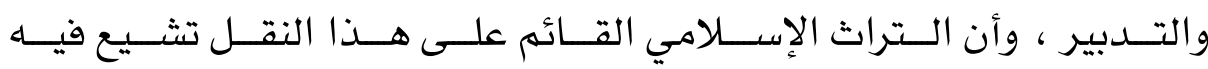

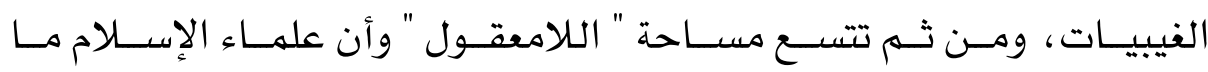

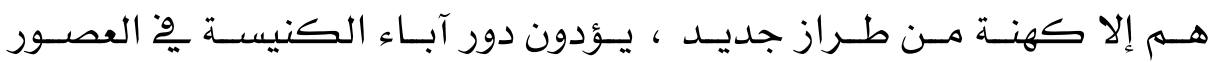

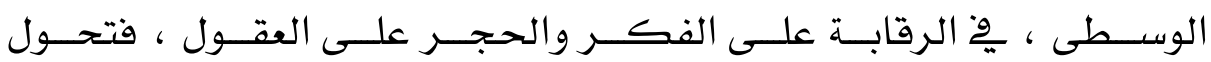

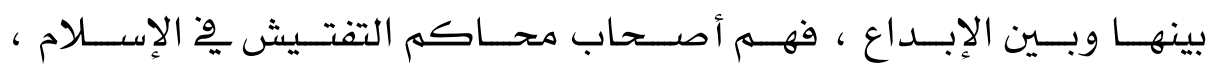

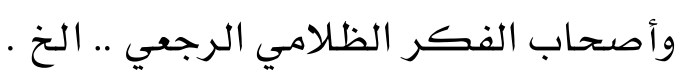

لمـا أخــذ أنصــار التــوير العلهـاني معرفتـهـه بالإســلام عـن طريـق الغرب أسفر عن هذا نتائج تهثل أهمها فيما يلي :

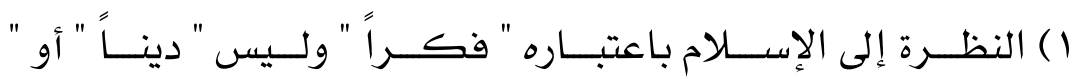

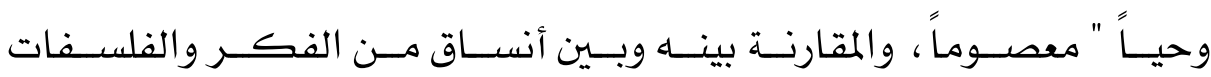

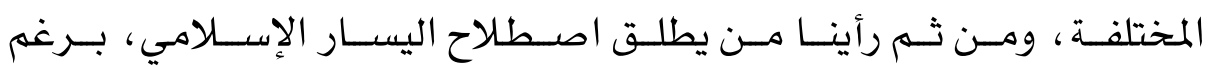

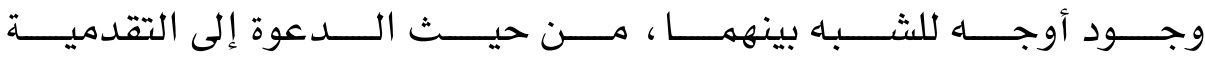

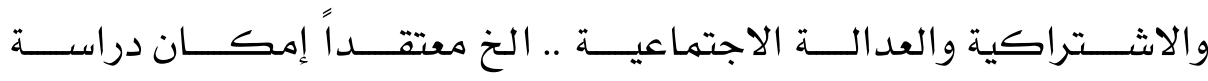

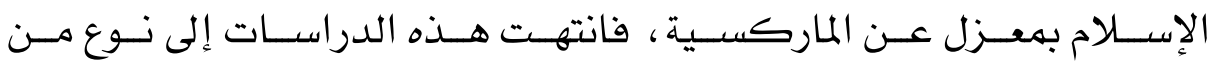

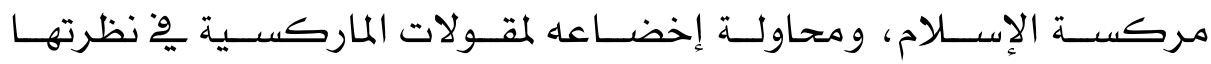
إلى الفكر والدين والمجتهمع .. الخ .

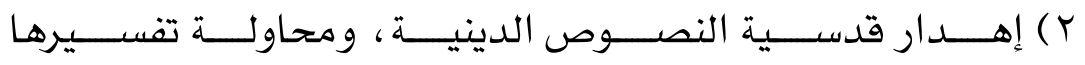

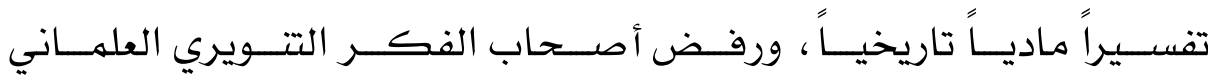

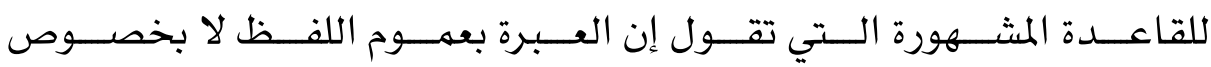

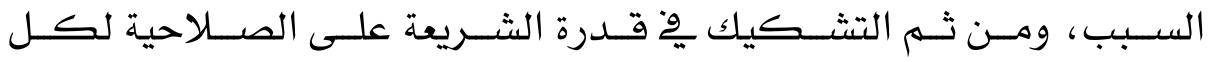




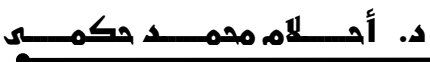

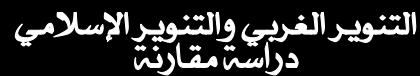

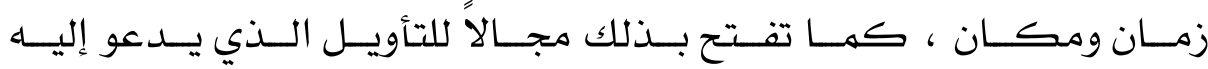
أنصار التتوير العلماني ومان

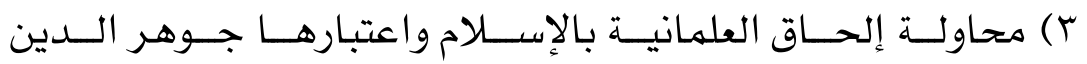
الإلهي ، من حيث سعيها إلى تحقيق مصلحة الإنسان وتحقيق النفع له

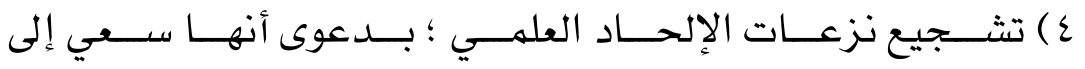

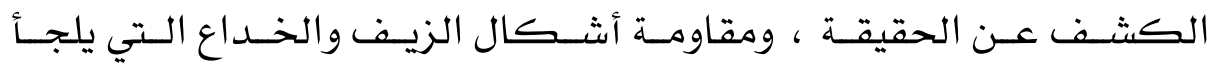
إليها المتدينون ويتواطؤ عليها المجتمع ·

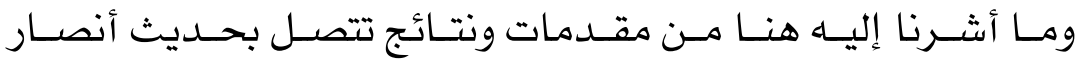

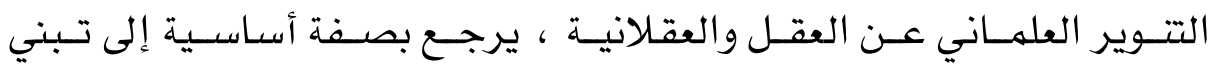

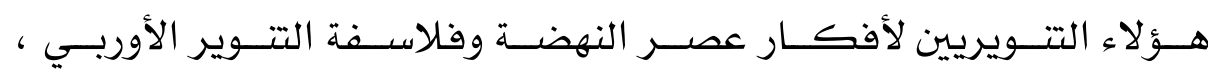

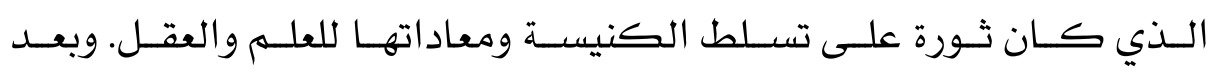

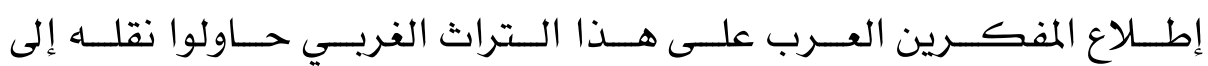

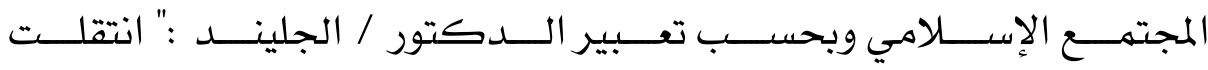

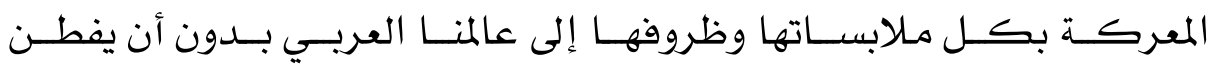

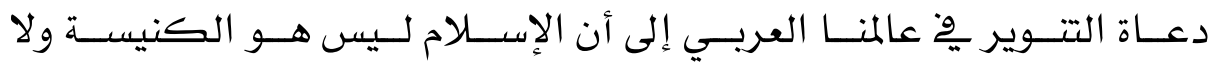

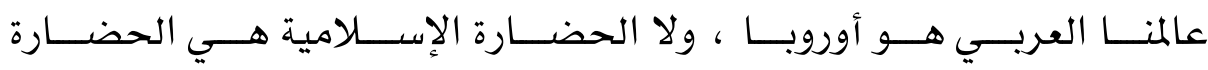

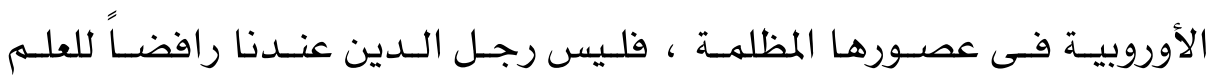
ولا محارياً للعقل . العائ.

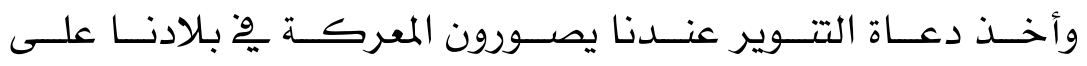

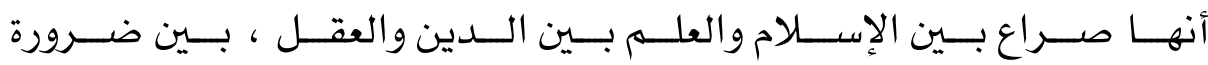

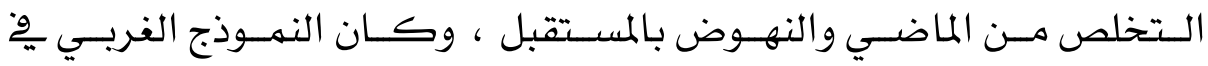




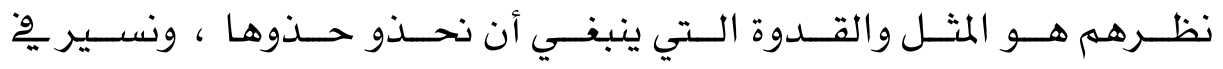

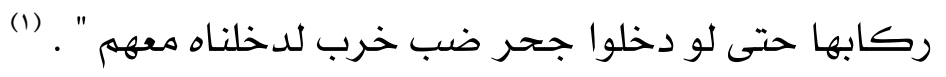

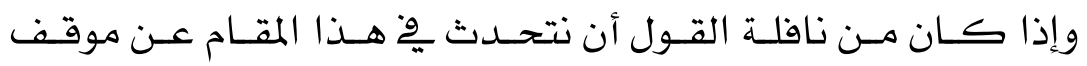

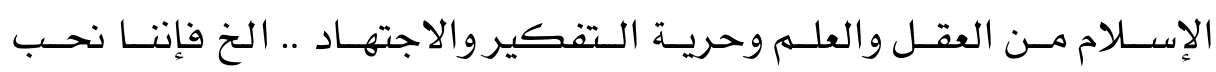
أن نركز يوْ هذا المقام على نقطتين أساسيتين :

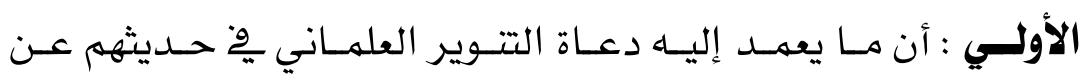

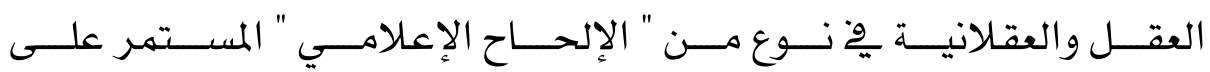

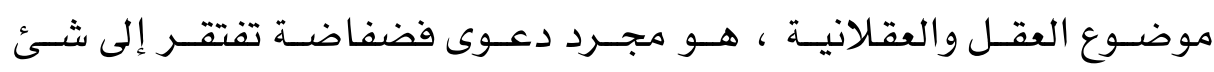

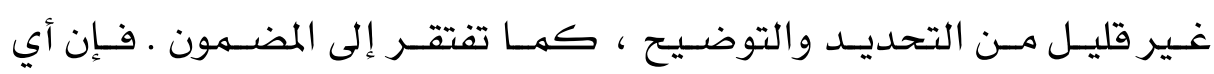

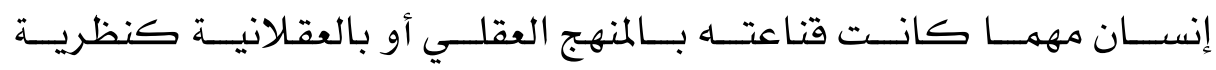

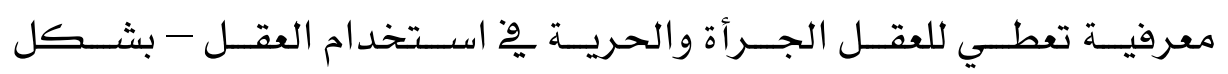

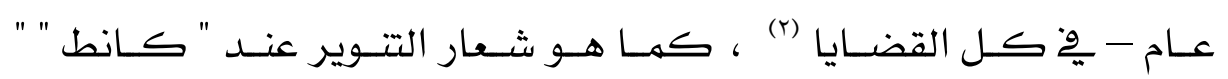

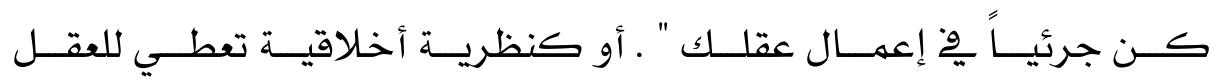

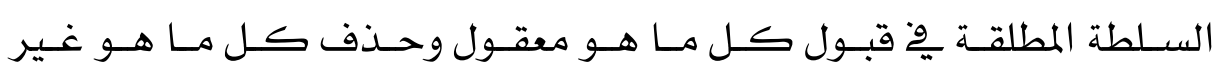
معقول (r) . وتطبيق ذلك على الأديان والعقائد بصفة عامة فئس

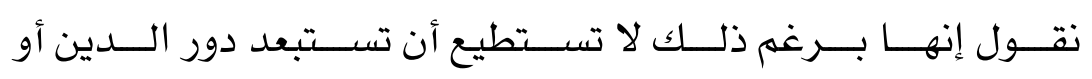

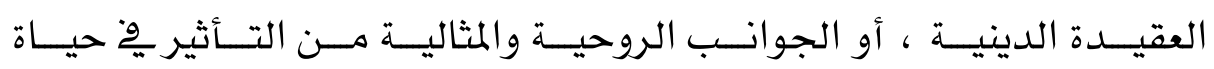

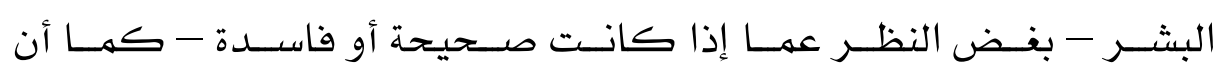

(') فلسفة التتوير بين المشـروع الإسـامي والمشـروع التغريبي د/ محمد السبد الجليند - صد 17 .

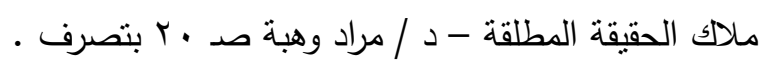
• المصدر السابق 
افـتراض ســيادة العقلانيــة ســـواء ـوْ الناحيــة المعرفيــة أو الأخلاقيــة فيــه نــوع مــن " المصـــادرة " علــى حريـــة الإنســان الــتي مــا فتــئ التتويريــون

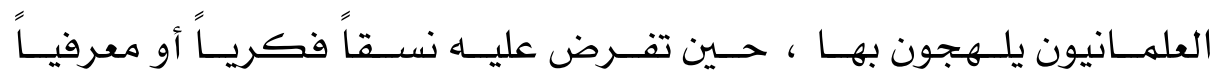

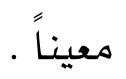

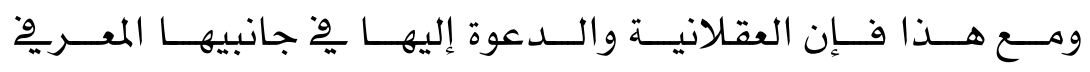

والخلقـي تظـل دعـوة قلـة مـن المـثقفين أو المتــورين الـذين ربهـا كـانـت لهـم

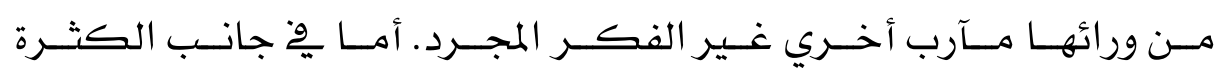

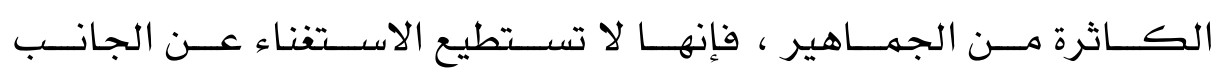
الروحهـي أو المثـالي الـذي يمثلــه لههم الـدين والعقيـدة الروحيـة بصــة عامـة ، وهـــه الضــرورة هـي الـتي مـن أجلـها تتابعـت دعـوات الأنبيـاء والرســل

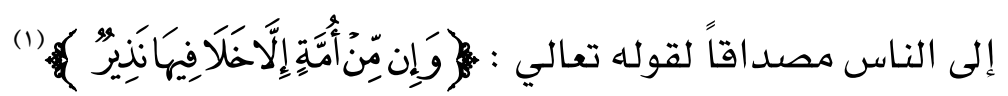
يقـــول الفيلســـوف الفرنســي " رينـــان " : " إن مـــن الممككــن أن يضـهـحل كـل شــيء نحبـهـ ويتلاشـى مـن أهـام أعينتـا ، وأن نبطـل حريـة العقـل ... لكــن يســتحيل أن ينهحــي التـدين مــن نقوســنا ، بـل سـيبقي

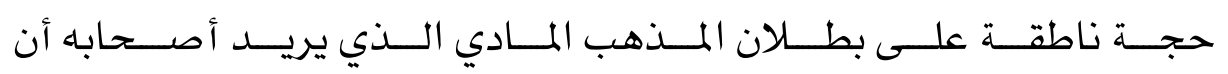
يحصروا حاجة الإنسان يوْ المطالب المادية الدنيئة للحياة الأرضية." (r)

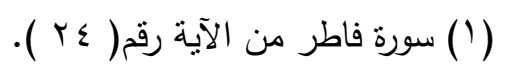

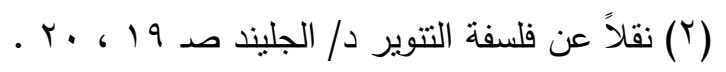




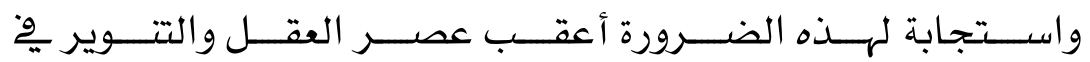

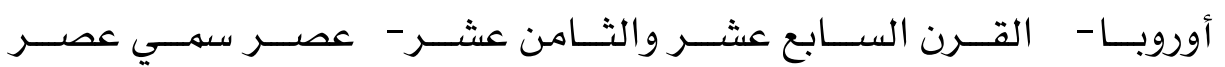

الإيهان قامت فيه فلسفة الإيهان بِّوجه فلسفة "كانط" العقلية. (1)

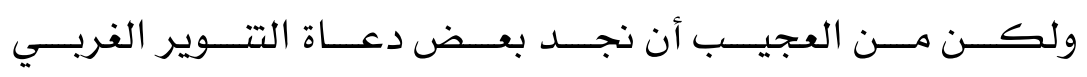

يسلكون إسقاط مقومات التتوير الغربي على الفكر الإسـلامي ،

وعـن ارتبـاط الإلحــاد بـالتتوير يقـول حسـن حنفـي " الإلحــاد هــــ

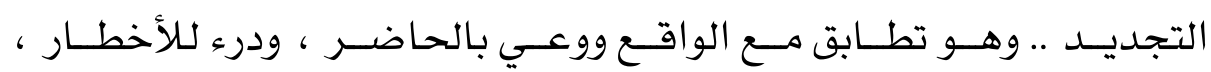

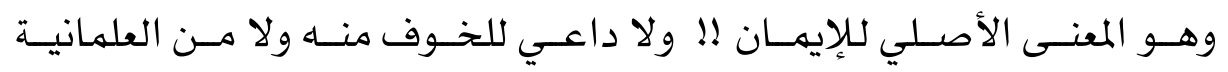

فهما حتميان "(r)" وهنو المعني

يريــــ أن يتحــول الإيهـان إلى الإلحــاد ، والإلحــاد مـن وجهـة نظـــه

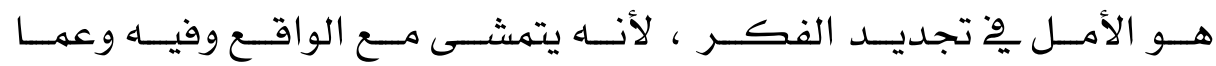

بالحاضر ولا خوف منـه .

هـذا المســلك الــني دعـي إليـهـ حسـن حنفـي وغـيره مهـن زعهـوا

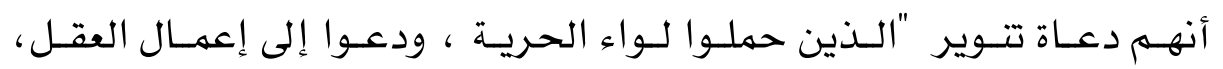

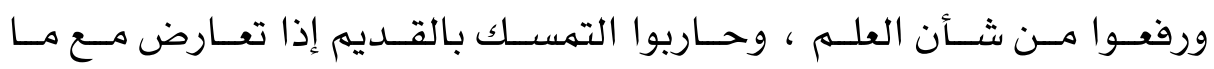

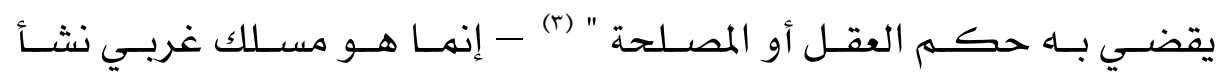

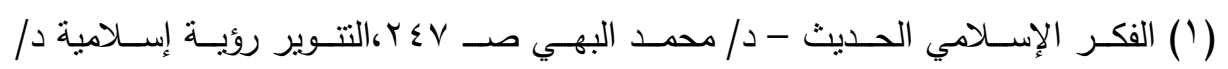

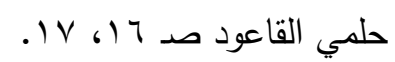

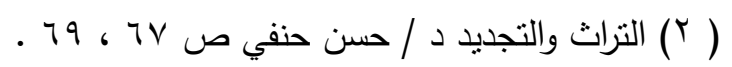

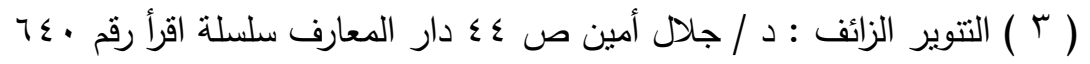




\section{التنوير الغريهي والتنتويجي الأسلامي دراستيمقارئي}

لظـروف معينـة وكــان لـرواده قضــية أمـام الكنيســة فهـل هنـاك قضــية

$$
\text { مع الإسـلام للخروج عنه بالإلحاد ؟ }
$$

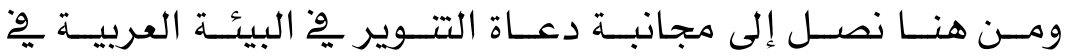

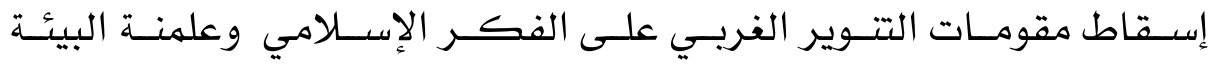
الإسـلامية ، وارتباط الإلحاد بالتوير .

التــوير الغربـي القـائم علـى الإلحــاد ، قــام ضــــ الكنيســة ،

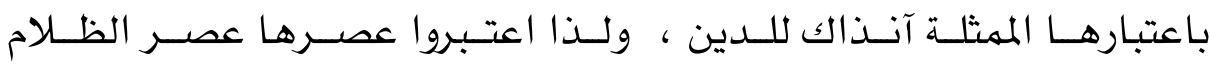

$$
\text { وما جاء بعدها بعصر التتوير · بلمباء }
$$

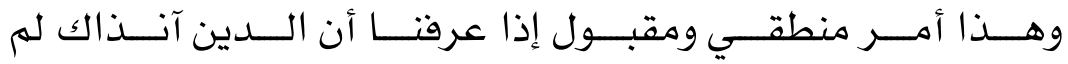

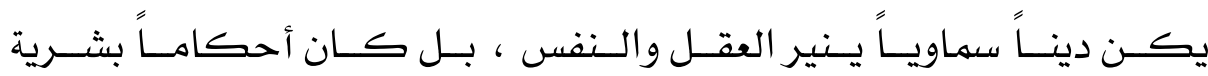

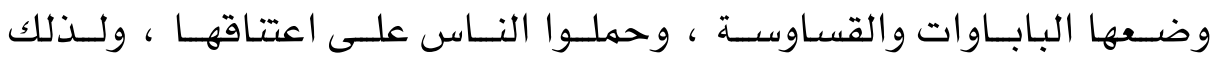

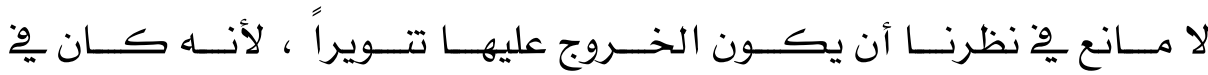

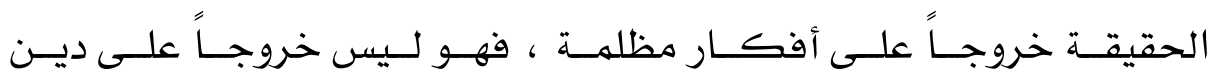

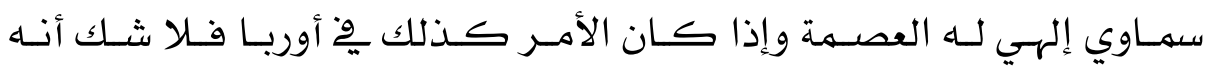
مختلــف تهـام الاخـتلاف وِّ الإســلام ، حيـث الـدين الصــحيح ، والـوحي

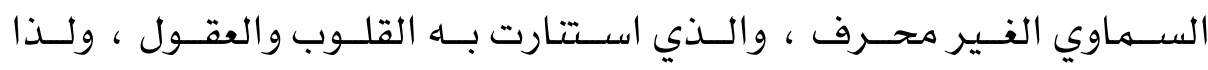
كان الخروج عليها ظلاماً وظلماً لا تتويراً .

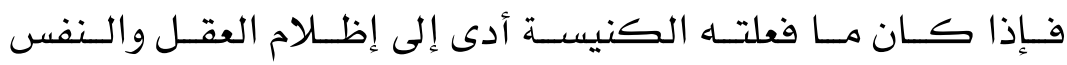

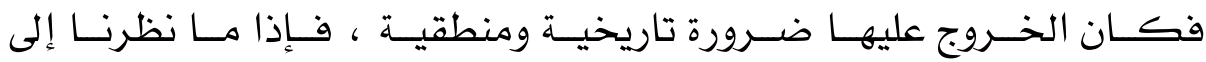

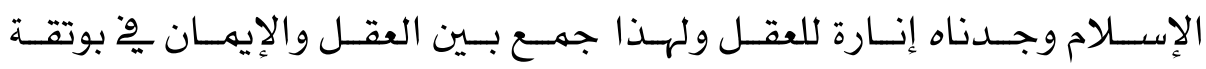




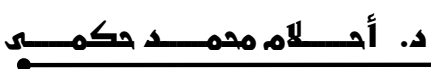

\section{التنوير الغريهي والتنيويجي الإسلامي دراستصنمقارئيخ}

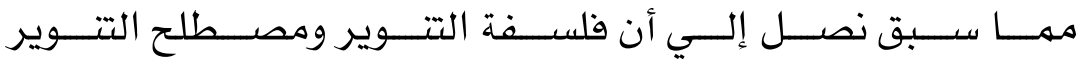

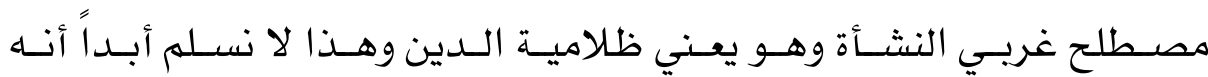

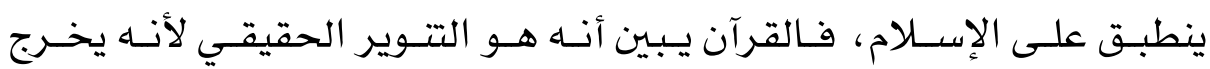

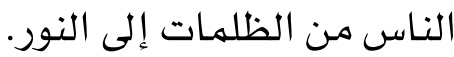

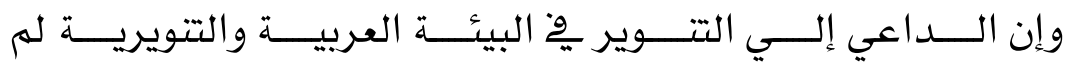

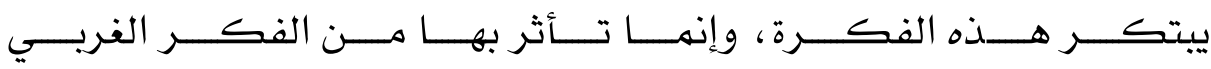

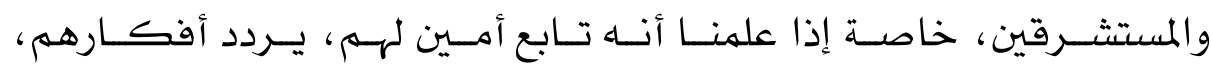

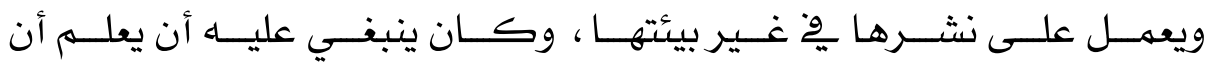

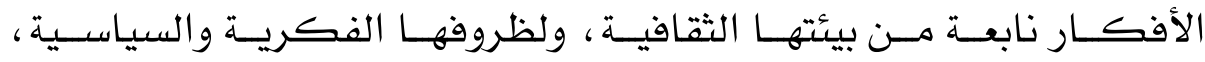

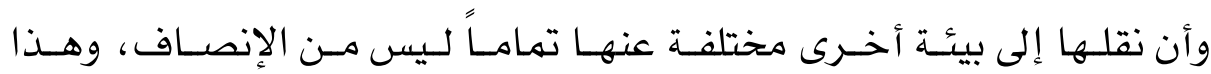

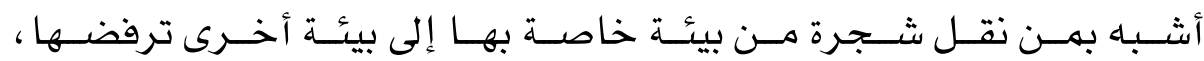
والنتيجة أنها بِ البيئة الجديدة ستذبل وتهوت. إذاً الظـروف الثقافيـة والدينيـة ِوْ البيئـة الإســلامية مختلفــة عـن

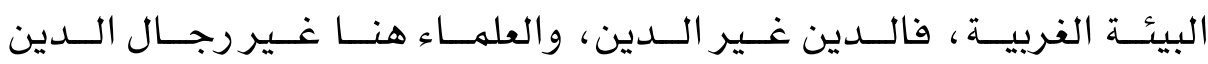
هناك.

\section{تأثر بعض دعاة التنوير الغربي بآراي المستشرقين.}

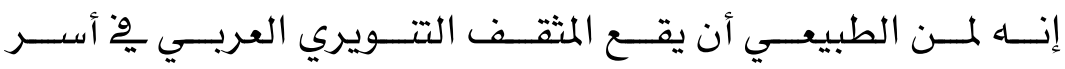

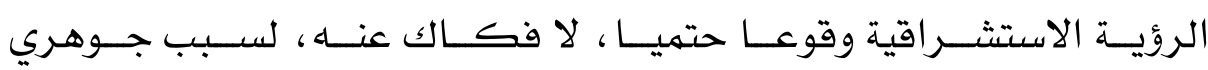

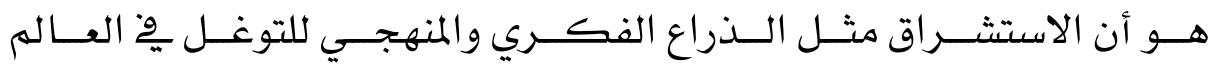

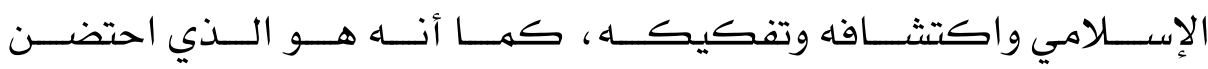

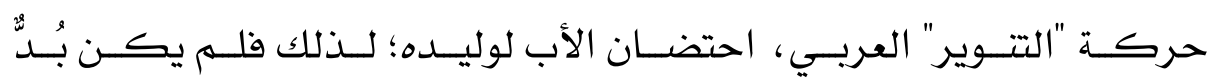
أن ينظر المثقف التتويري لذاته وتراثه بعيون استشراقية غربية. 


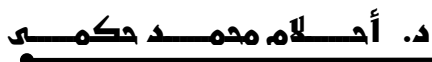

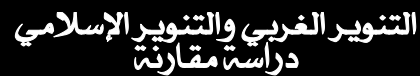

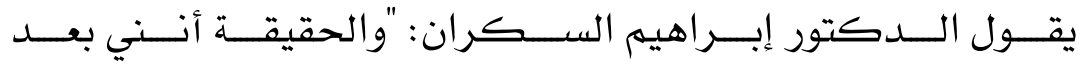

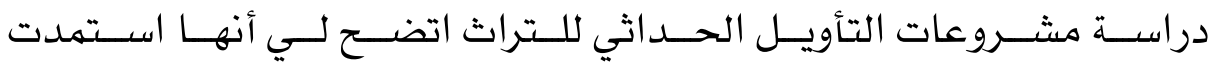

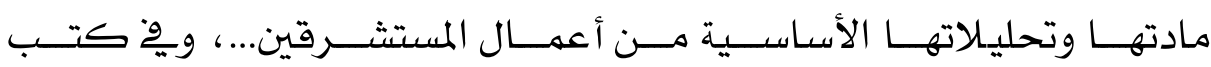

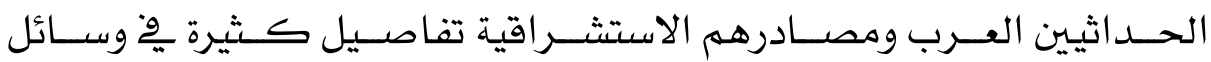

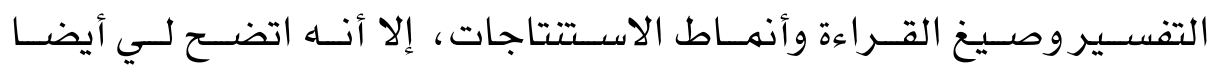

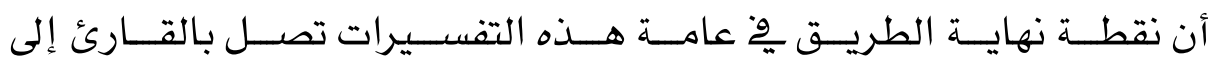

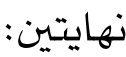

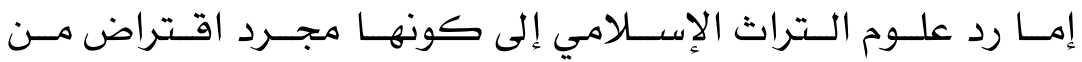

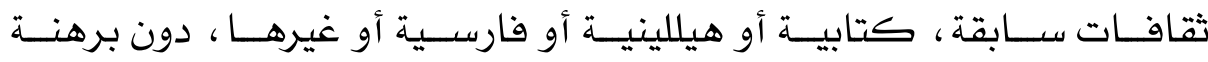

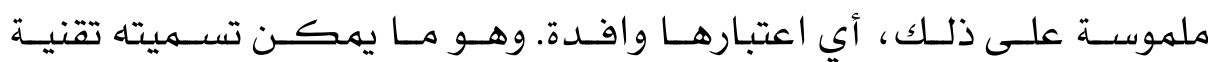

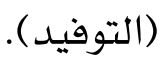

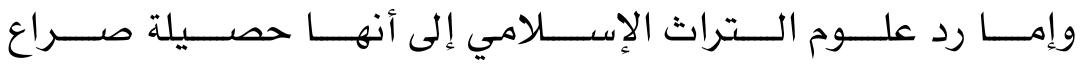

سياســي، وليسـت حصــيلة نظــر موضــوعي، حسـب مقتضــيات الــلائل

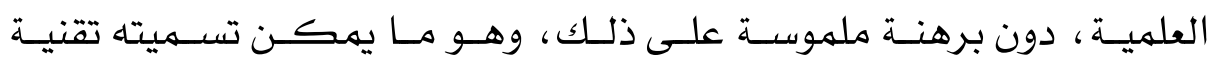

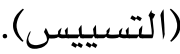

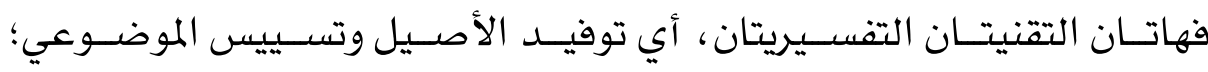

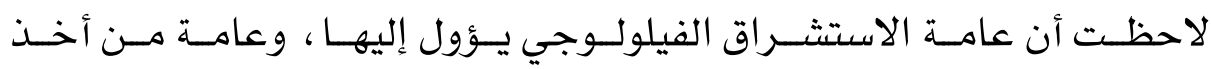

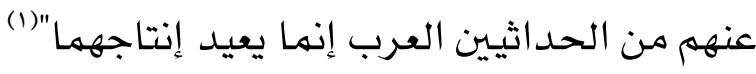

( ) التأويـلـ الحـداثي للتــراث: التقنبـات والاسـتمدادات، إبـراهيم بـن عهـر السـكران، دار

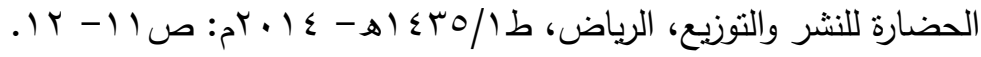


ويقـول الثــريف "زروخـي" عـن مشـروع محهـــ أركــون باعتبـاره

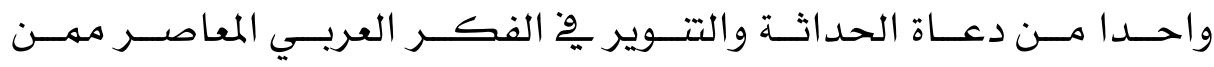

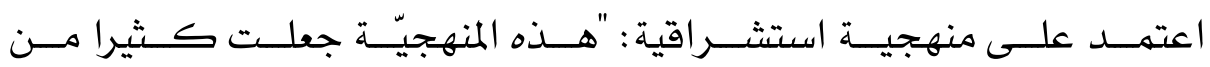

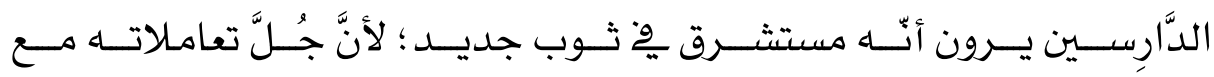

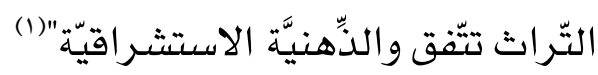

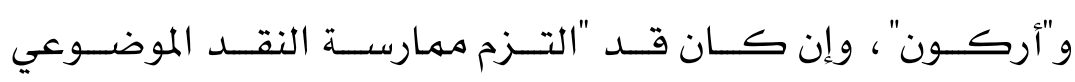

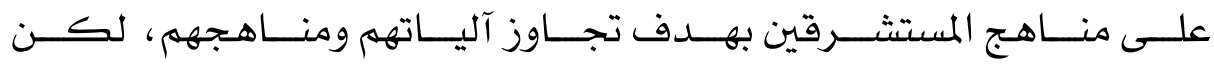

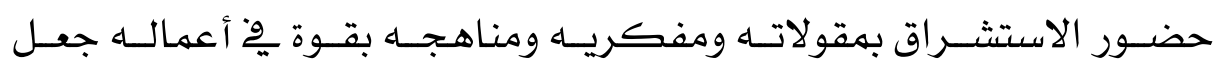

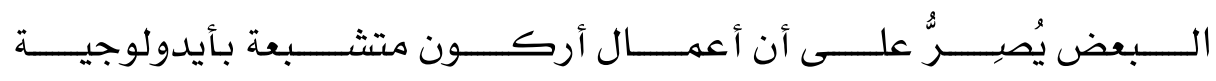

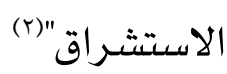

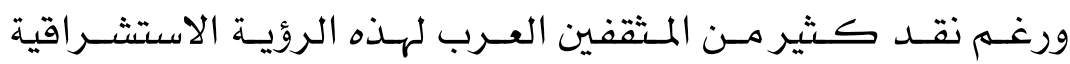

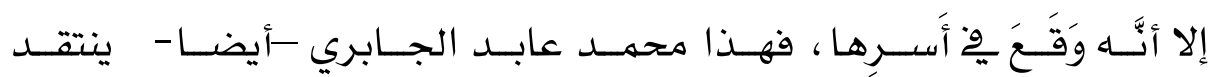

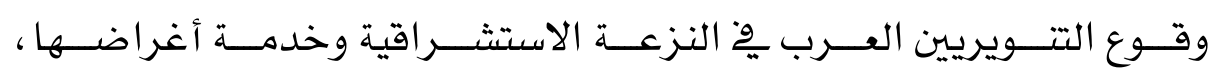

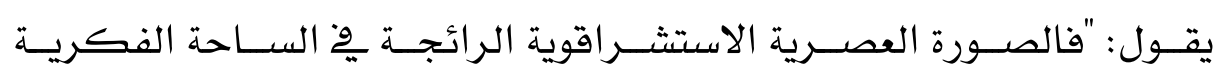

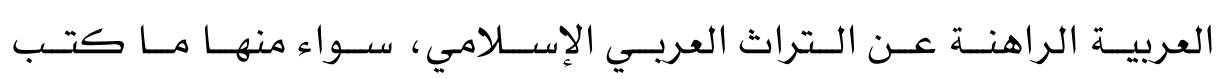

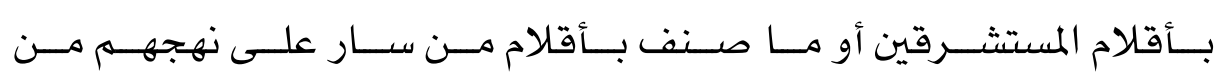

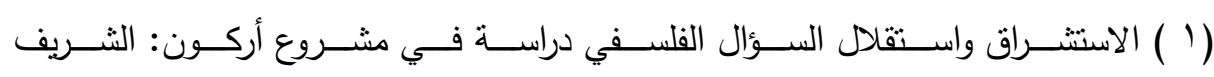

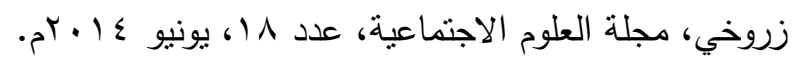

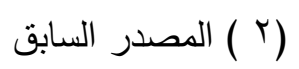




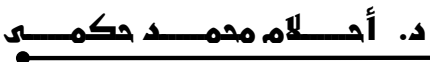

\section{التنوير الغريهي وإلتنويجي الإسلامي درأستمقارئي}

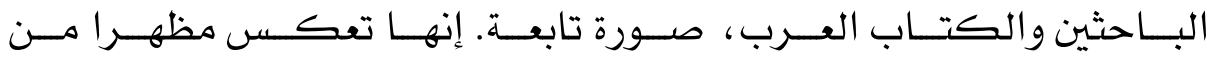

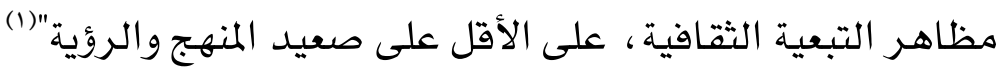

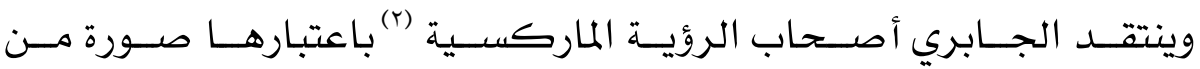
صــور الاستشــراق: "بكونهـا تعــي تبعيتهــا للهماركســية ، وتقــاخر بهــا؛

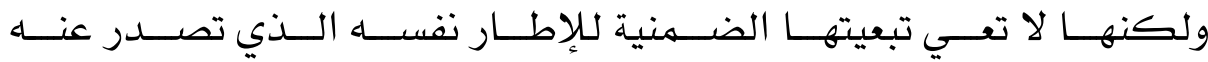

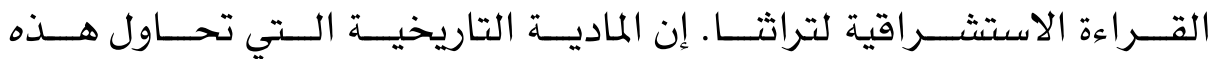
الصــورة اعتمادهــا ، كهـنهج مطبـق، ولـيس كهـنهج للتطبيـق، مـؤطرة

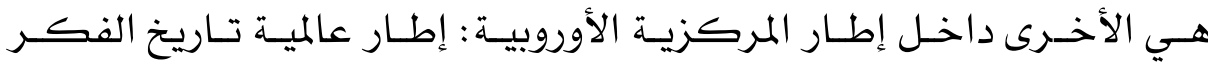

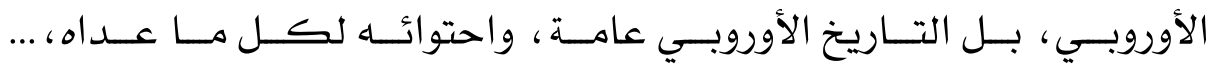
وهــا يكفـي ليجعـل الصــورة الماركسـية لتراثتـا العربـي الإسـلامي تقـوم

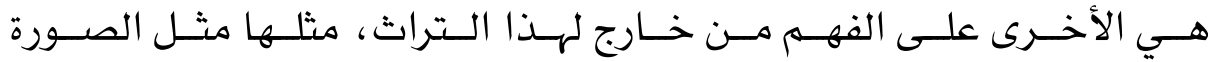

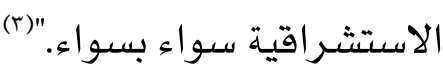

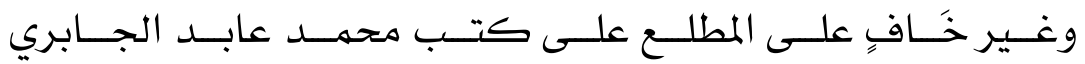

وقوعاه هو بذاته فيها انتقد غيره فيه ، وعابه عليه.

ونتيجـــة لـــلك له يكــن التــوير العربــي إلا خادمــا للمشــروع

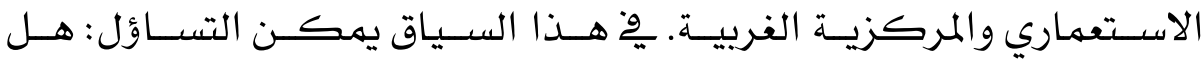

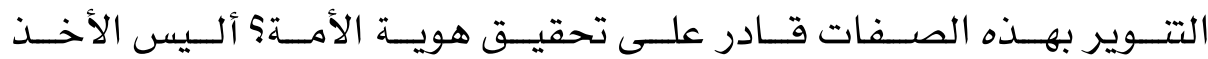

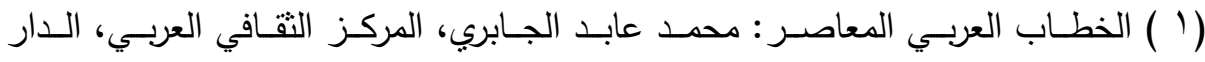

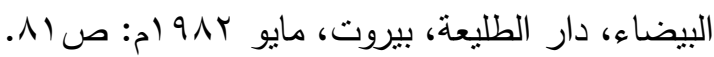

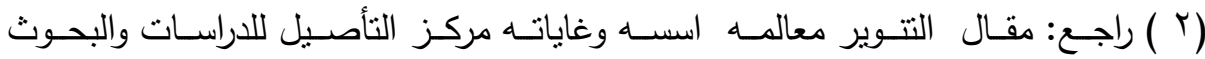

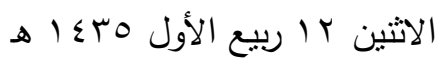

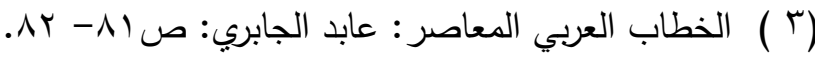




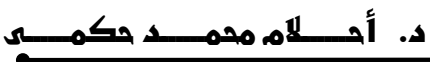

\section{التنوير الغريجي وإلتنويتي الأسلامي}

بنهــوذج التــوير الفريـي إنهـا هـو تفريـب للأمسة عـن ذاتهـا وهويتهـا وتـذويب لها يِّ الآخرى ألا تتوفر الأمة على مرجعية صالحة للانطلاق منها؟

وأخـيرا يمكــن القــول إن التـــوير العربــي كـــان مجــرد نقــل

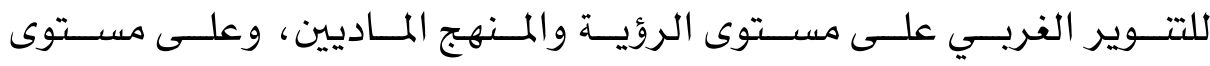

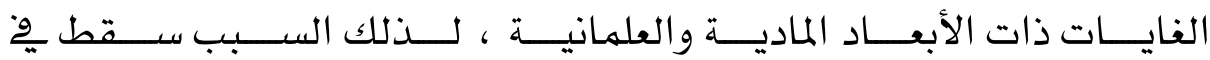

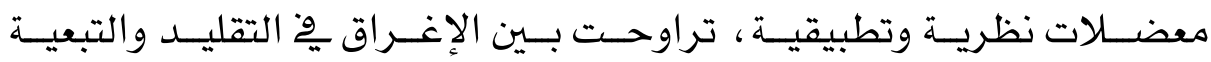

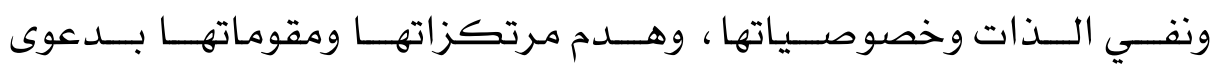
الماضوية ، كما لم يسلم من آفات التتاقض والانتقائية والإسقاط.

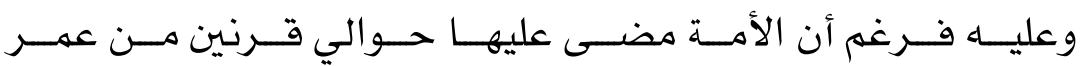

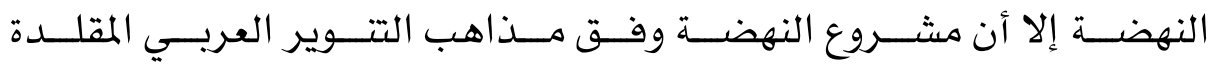

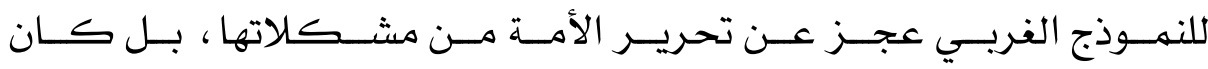

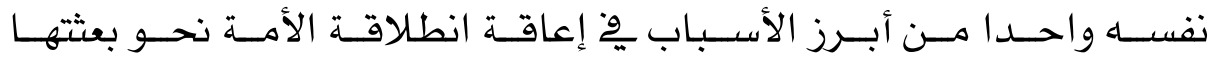

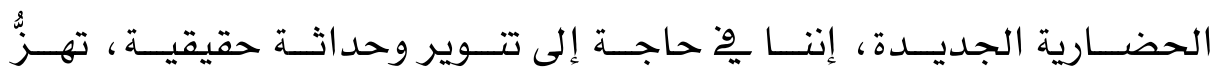

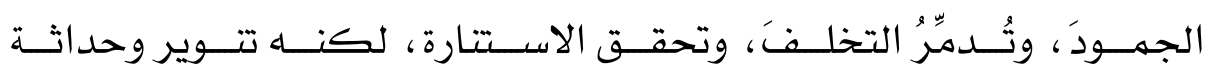

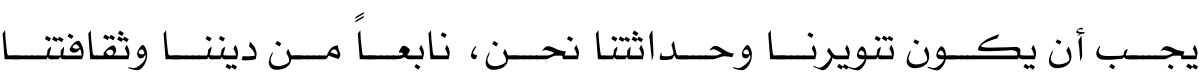

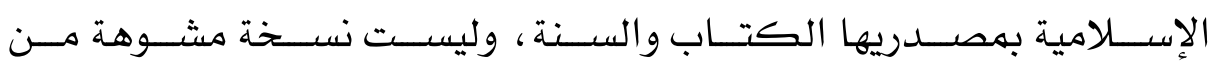
التتوير والحداثة الغربية.

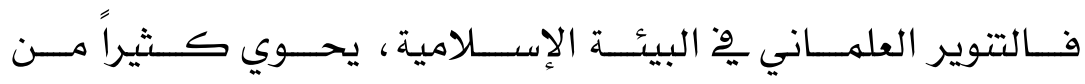

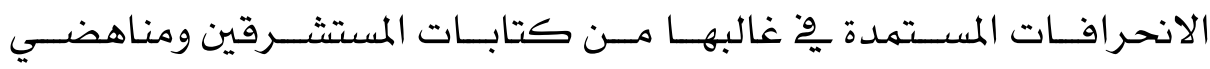
الوجود الإسـلامي يخٌ الغرب والشرق. 


\section{الفصل الثالث}

\section{التنوير الإسلاهي ومقوماته.}

$$
\text { ويشتمل على مبـثثين: المبـحث الأول: مفهوم التتوير الإسـلامي ومصدره }
$$




\section{البمشث الأول \\ مفهوم التنوير الإسلامي ومصدره}

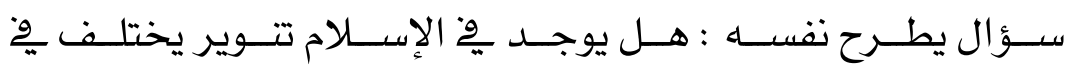

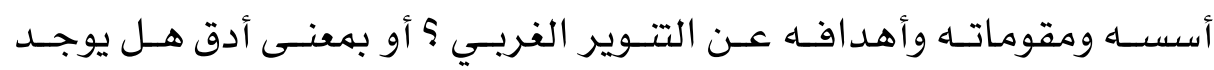

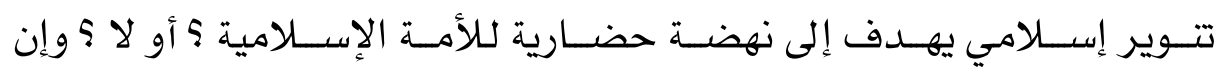

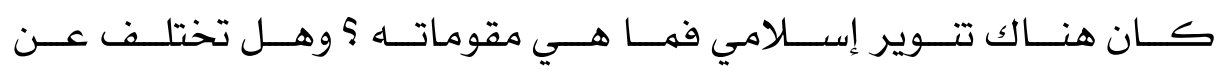

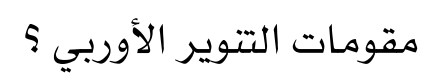

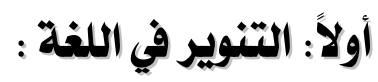

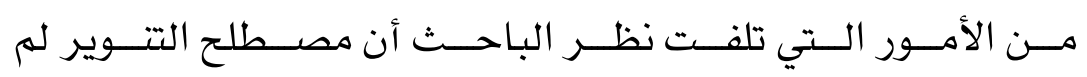

تعرفـهـ معــاجم الفكــر والثقافـة عـبر تــاريخ الفكـــر الإســلامي ، وإن

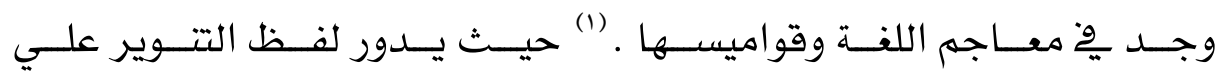
معـاني : الإنـارة والإضـاءة والحسـن ، والإســفار ، والكشـف ، وانجــلاء

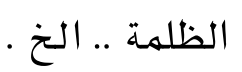

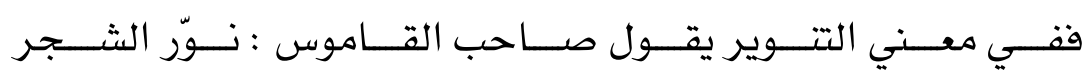

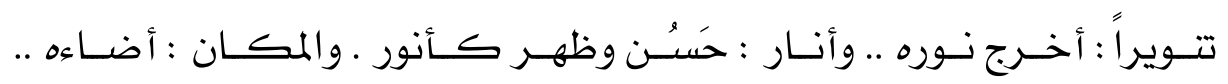
والأنور : الحسن. (r)

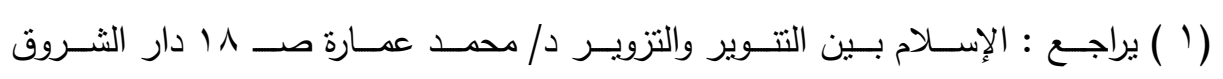

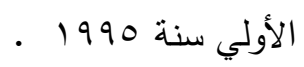

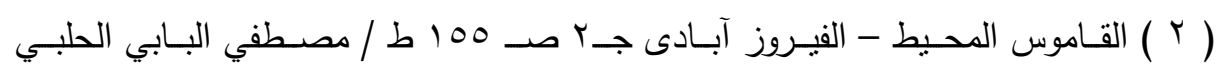

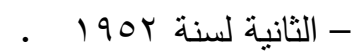




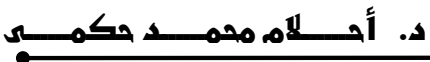

\section{التنوير الغريجي والتينوير الأسلامي دراستيمقارئي}

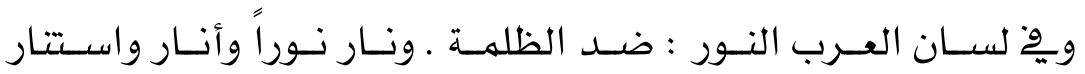

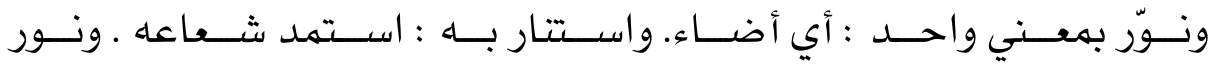

الصبح : ظهر نوره . (1)

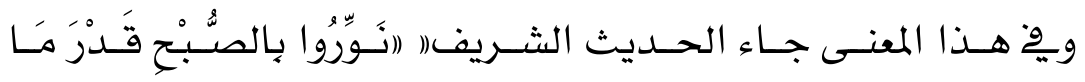

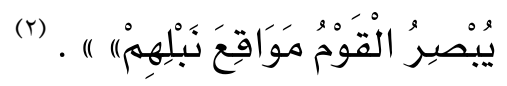

أى صـلوهـا ســاعة التــوير ســاعة إســفار نـور الصـبـاح علـي إرادة

$$
\text { تحديد وقت الصلاة . (r) . }
$$

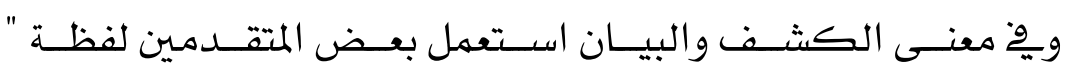

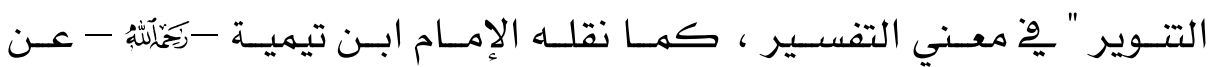

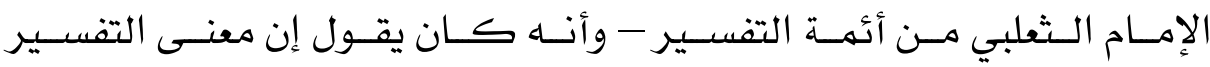

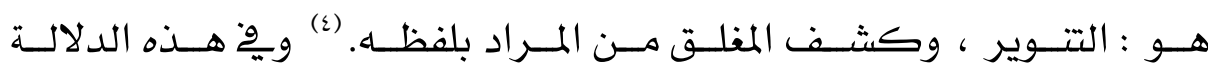

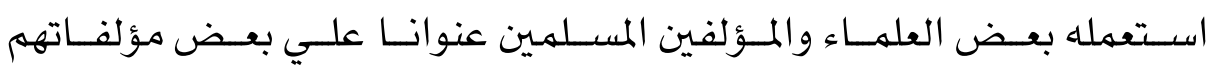
مُ20 العلوم الثرعية واللغوية .

(1 ) القـاموس المحـبط - الفيـروز آبـادى جـ كـــ 100 ط / مصـطفي البـابي الحلبـي

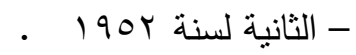

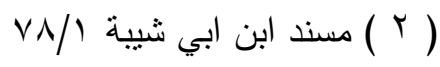

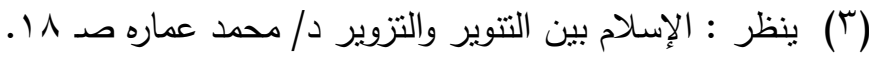

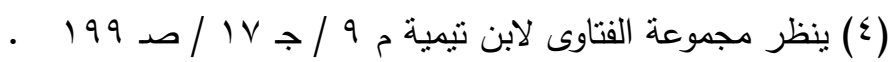

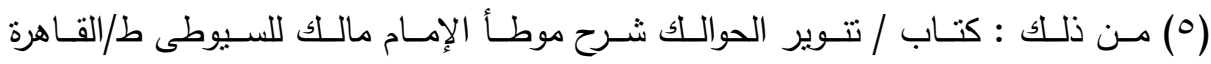

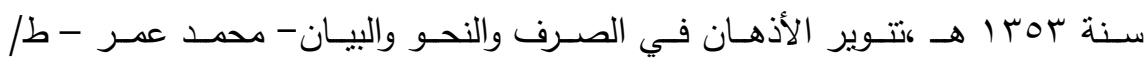

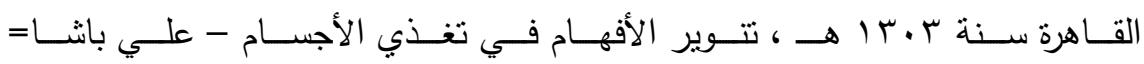




\section{ثانياً: التنوير في القرآن الكريم والسنة:}

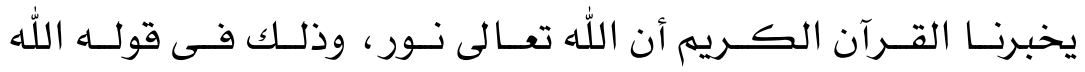

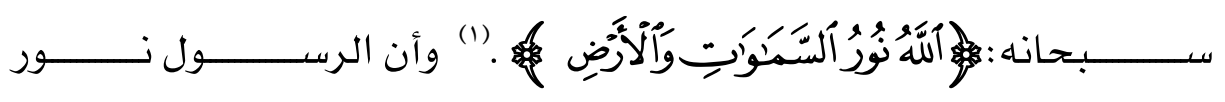

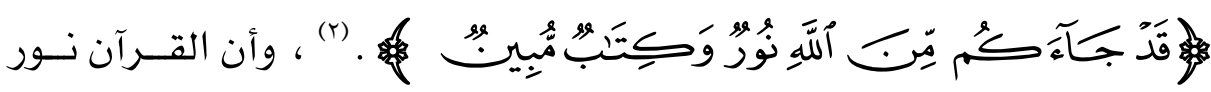

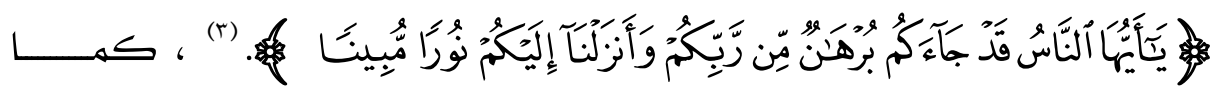

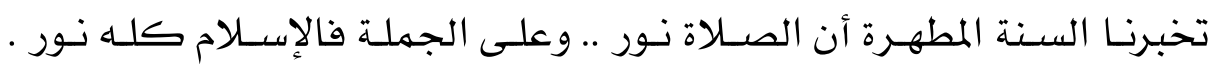

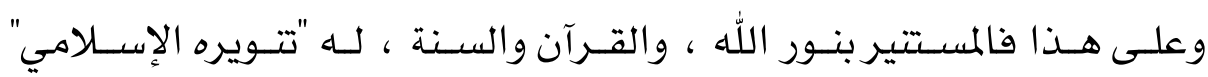

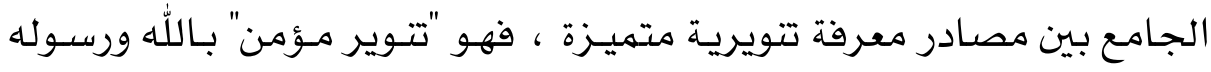

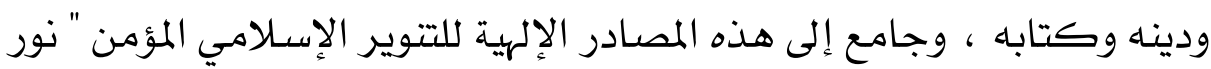

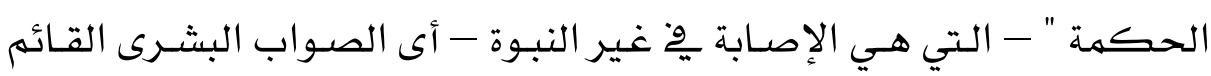

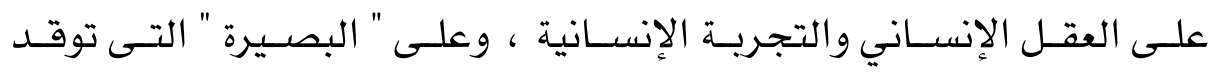
مصابيحها فى القلب الإنساني عبـادة الحكيم لأحكىم الحـاكمين .فنحن

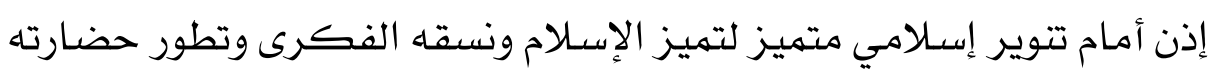

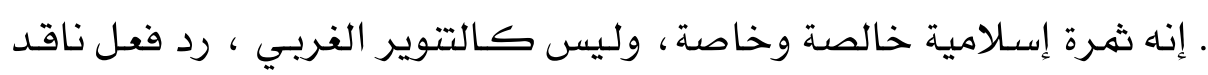

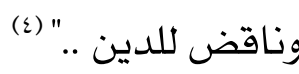

= مبـارك- القـاهرة سـنة r. با هـ ، تتـوير الحلك في رؤبـة النبـي والملك -جـلال

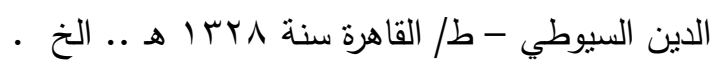

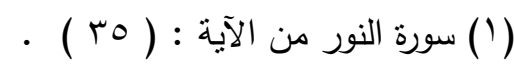

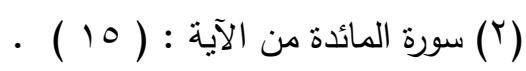

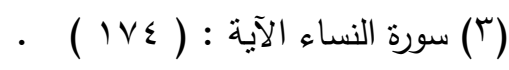

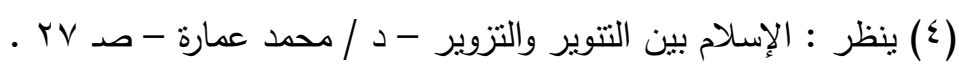




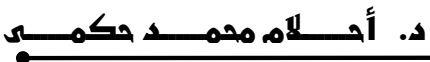

وإذا كـان مـن معسانى التـوير الكشـف والبيـان والإسـفار والإضـاءة

والظهور .. فإن الإسـلام بهذا المعنسى كله دعوة إلى الكشف عن الحقـائق ، ورد الأباطيل ، والاهتداء بنـور الله في الخـروج مـن ظلهـات الجهالـة والشـرك والدخول فى نور التوحيد والإيهان ، الذى ينعكس أثره على العبـد تسـديداً

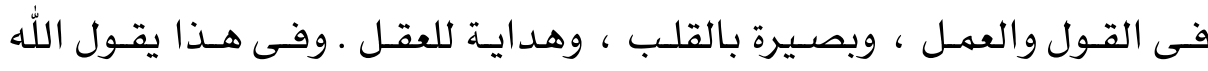

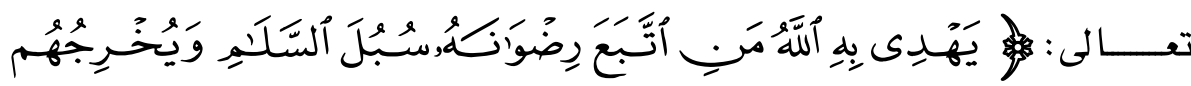

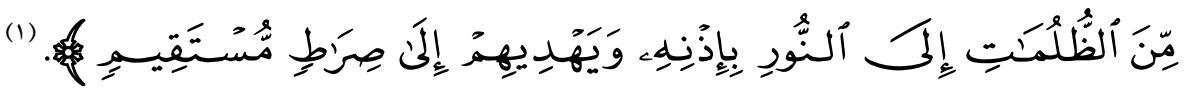
كهما أنـه دعـوة إلى إعمال العقل والوصـول بـه إلى حقيقـة الكـون، ومـن ثم الوصـول إلى البراهين القاطعـة على قـدرة خالقـه جـل وعـلا وكهـال

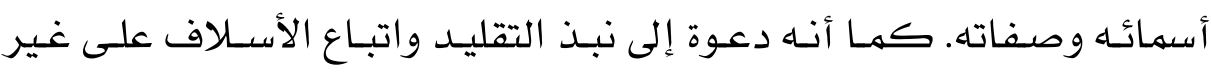

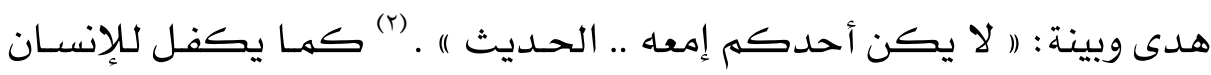

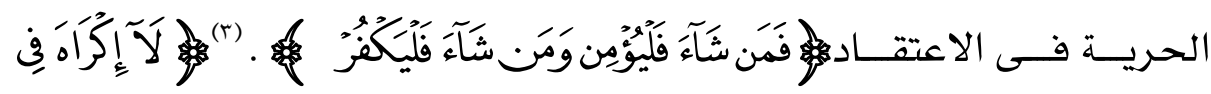

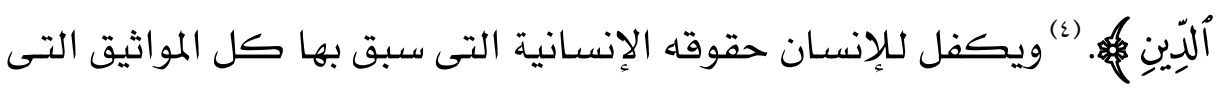
وضعت فى العصور المتأخرة.

وبهـــا نسـتطيع القـول : إن التــوير الإســلامي ينبـع مــن الإســلام

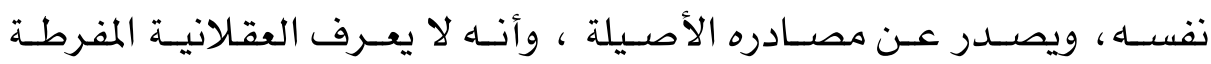

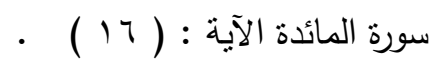

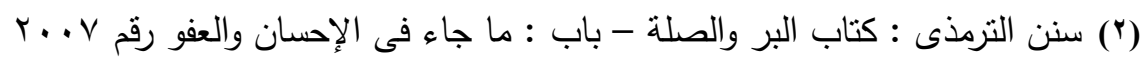

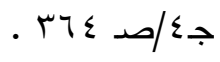

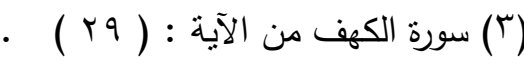

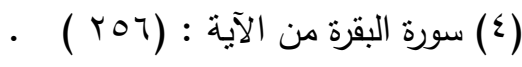




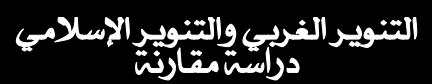

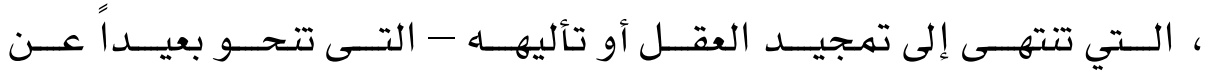

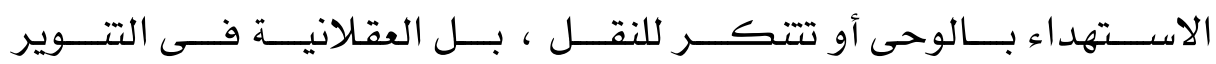

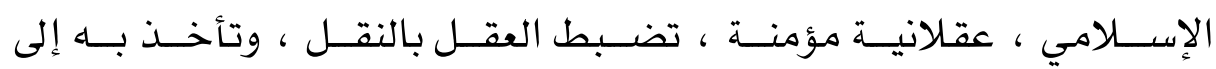

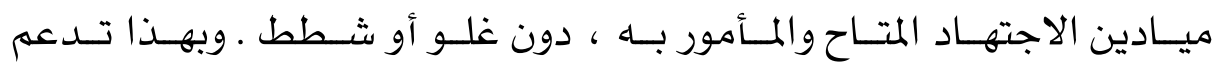

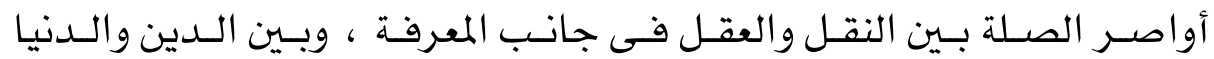
فـى جانـب الوجـود ـ.كهـا أن التــوير الإســلامي لا يعـرف الحريـة المنفلتــة

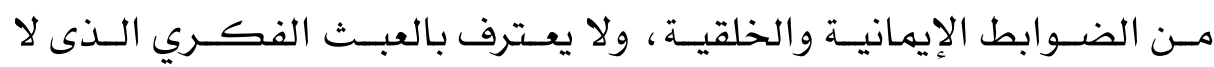

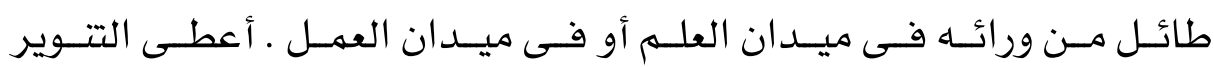

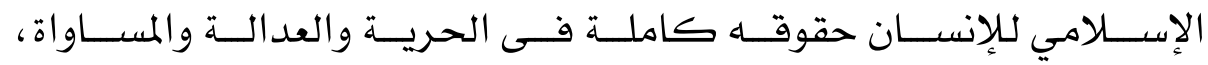

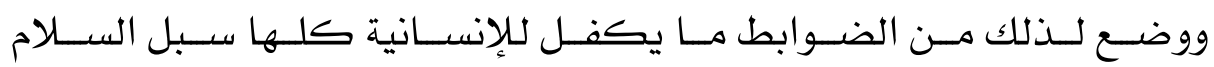

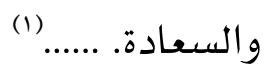

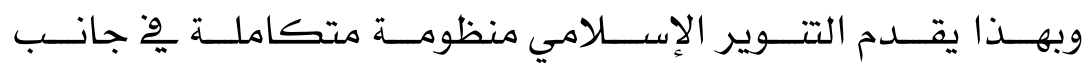

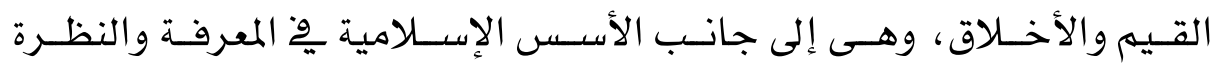

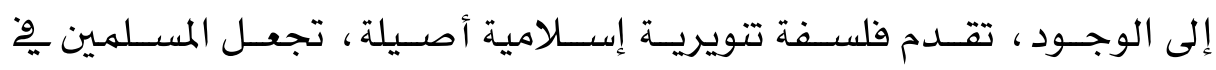

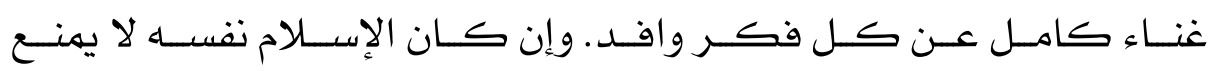

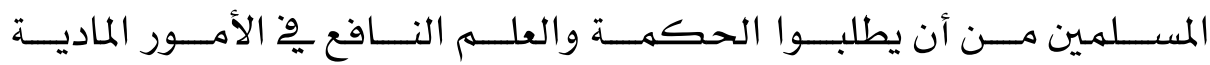

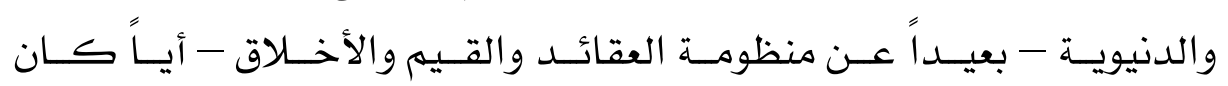
مصدرها.

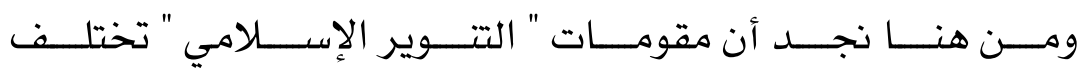

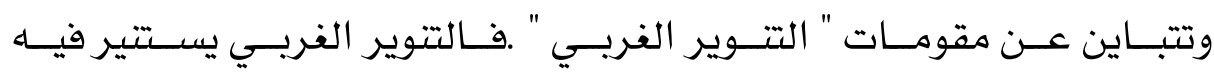

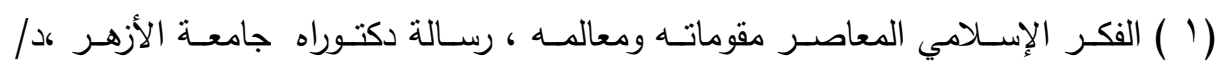

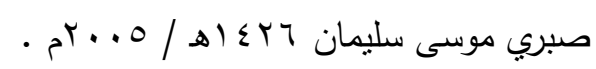




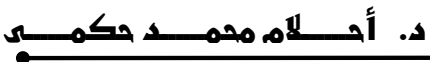

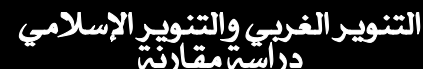

الإنســـان بــنقض الــدين وتجـــاوز شـــائع الله ، أمــا التـــوير الإســلامي يستتير فيه الإنسان بالإسـلام · لئ.

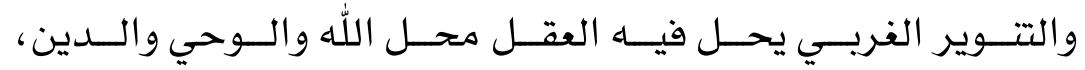

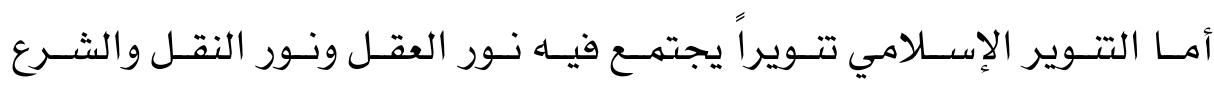
والدين.

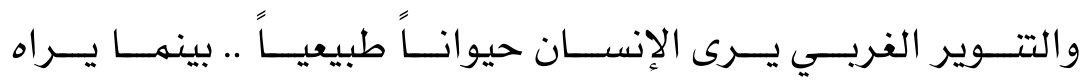

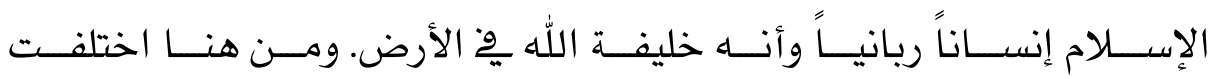

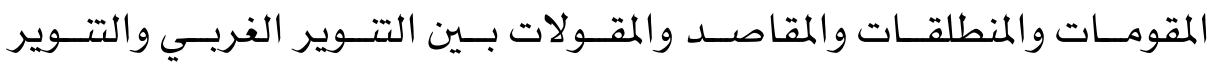

الإسـلامي (1)

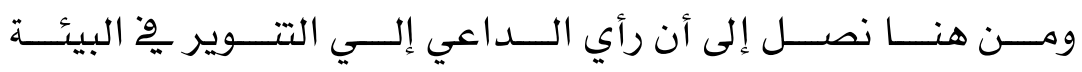

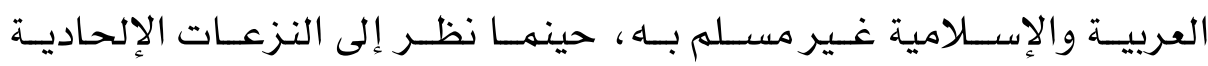

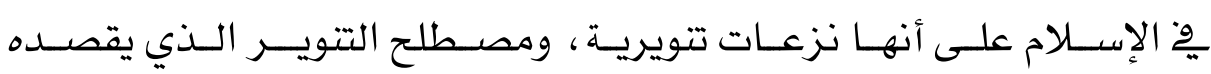
هو المصطلح التتويري الغربي الذي يهجد العقل الإنساني.

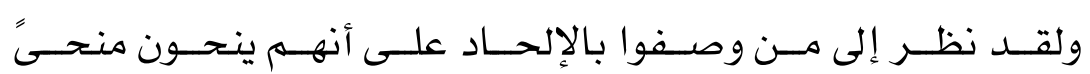

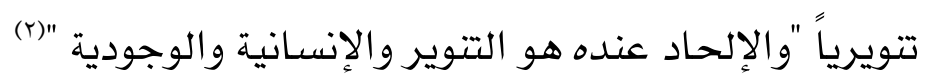

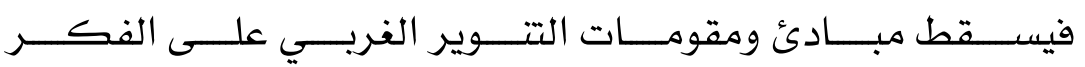

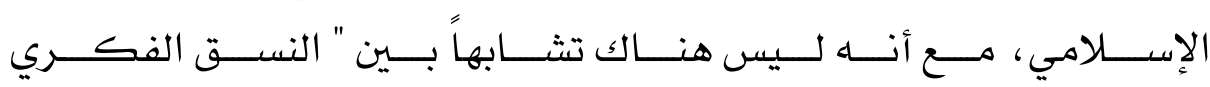

(1 ) التقدم والإصــلاح بـالتتوير الغربـي ؟ أم بالتجديــ الإسـلامي د / محمــ عمـارة ص r r r r بتصرف

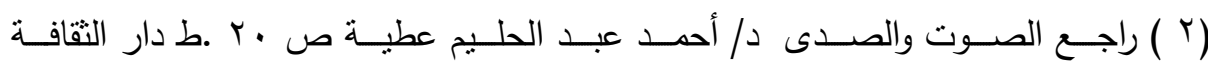

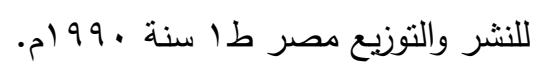




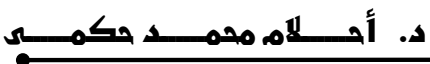

\section{التنوير الغريهي والتنتويجي الإسلامي \\ درأستيمقارئي}

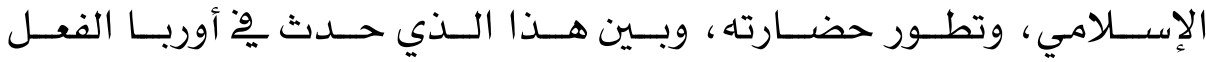

الكنســي منــه " رد الفعـل التــويري " حتـى يكــون هنــاك لاســتدعاء هــذا

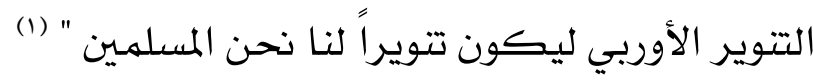

فـنـحن إذن أمـام تــوير إســلامي فيـهاه معرفـة تتويريـة مــن النقـل

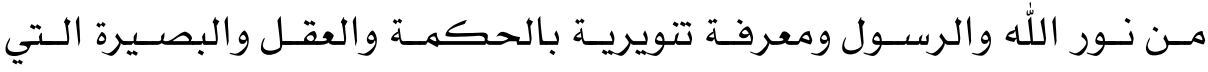

تضيء قلب وعقل المسلهم.

( ) الإسلام بين التتوير والتزوير د/ محمد عمارة ص ع ؟ . 


\section{المبمث الثاني}

\section{مقومات التنوير الإسلامي}

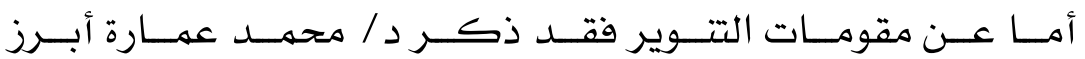

مقومات التتوير الإسـلامي ِِّ النقاط التالية:

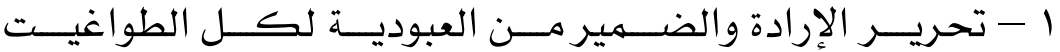

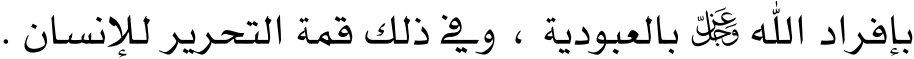

r - واعتبـــار القـرآن رأي " النقــل " والــدين والشــرع نـوراً للبصــر

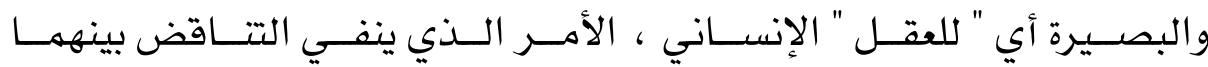

حتى ليصبح لا غنى ولا استفناء لأحدهما عن الآخر .

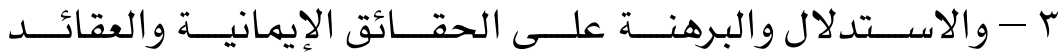

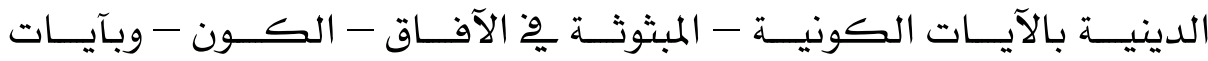

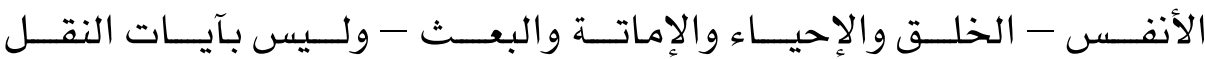

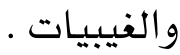

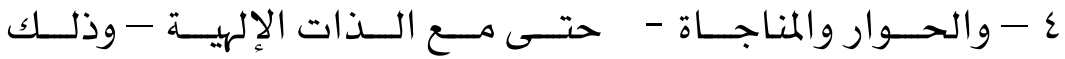

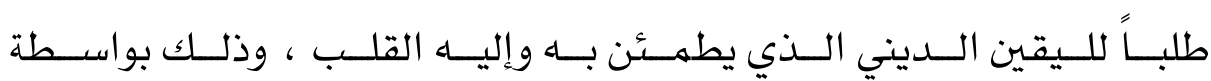

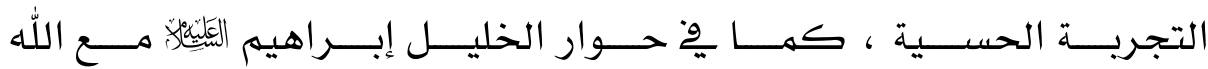

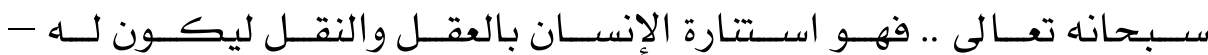

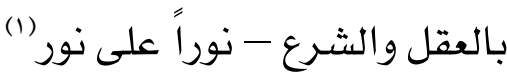

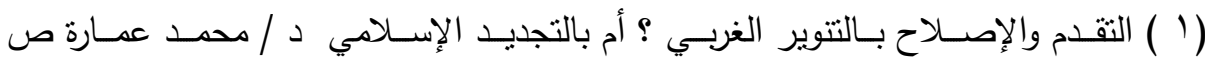
. r) 6 r. 


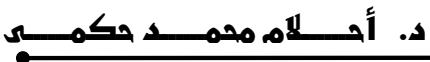

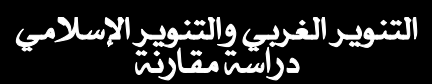

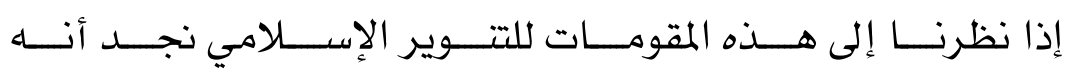

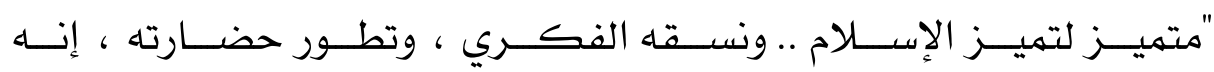

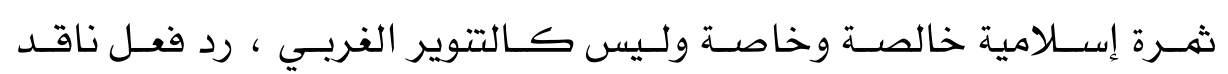
وناقض للدين "(1)

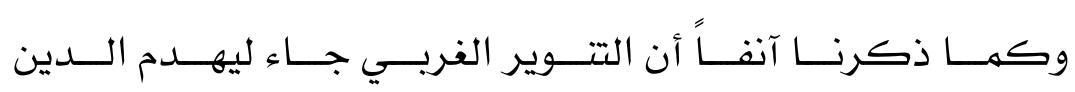

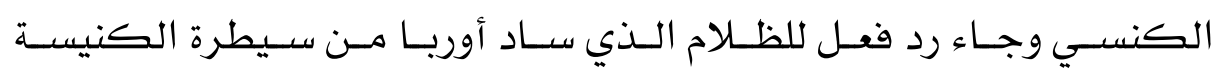

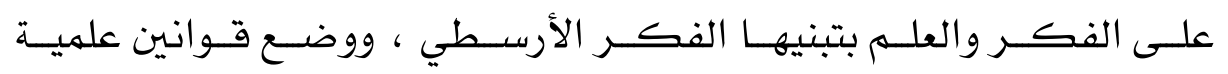

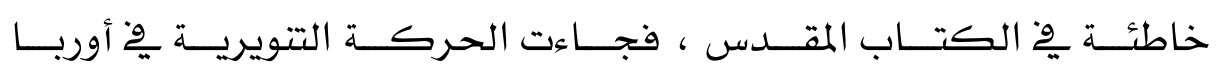

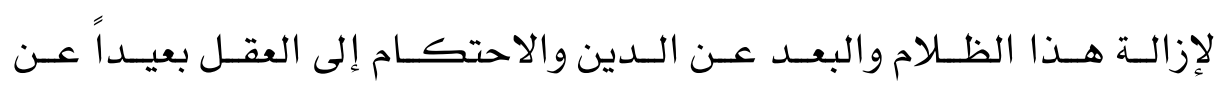

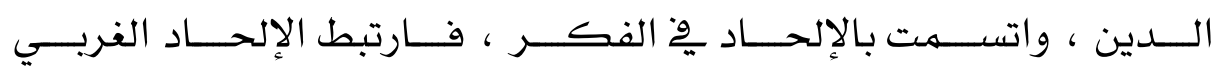

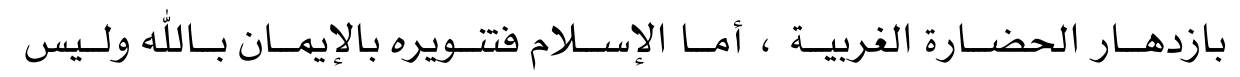
بالإلحاد . باردهاد

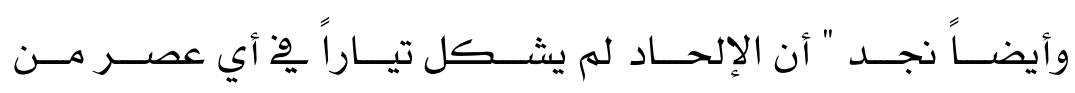

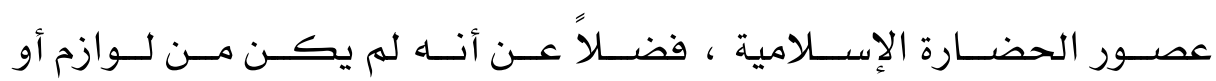

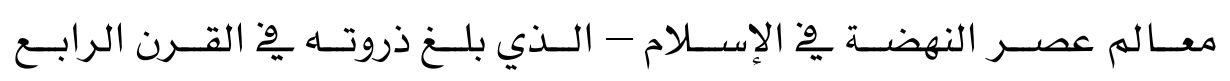

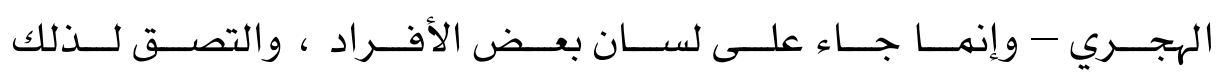

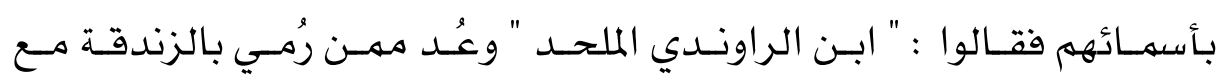

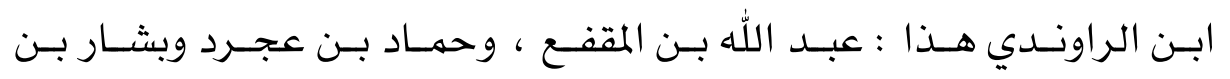

(1 ) الإسلام بين النتوير والتزوير د/ محمد عمارة ص VY .

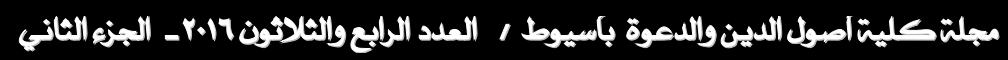




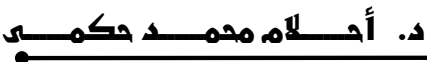

\section{التنوير الغريهي والتنيويجي الإسلامي

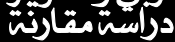

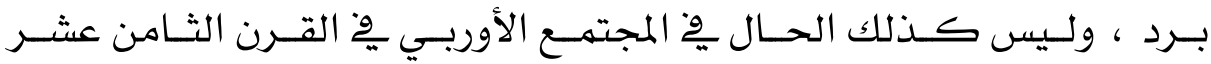

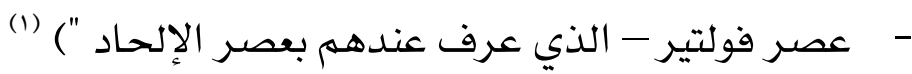

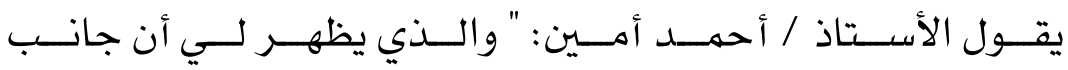

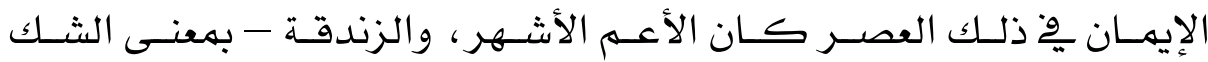

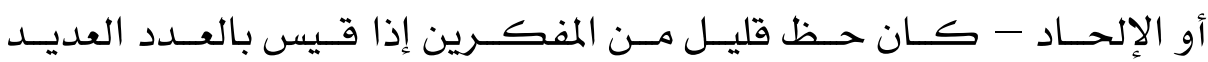

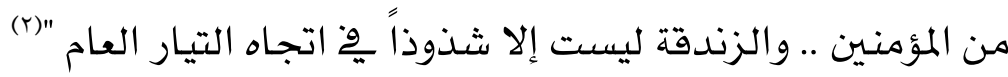

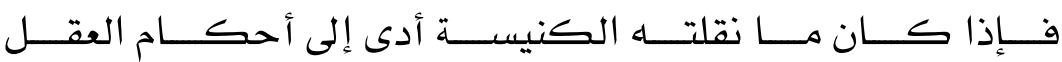

والـنفس فكــان الخــروج عليـــ ضــرورة تاريخيـة ومنطقيـة، فـإن مــا جـاء

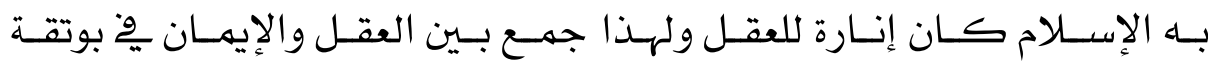
واحدة.

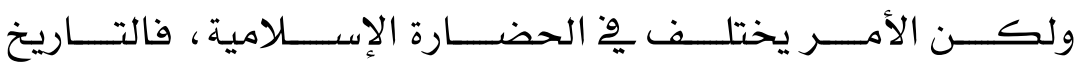

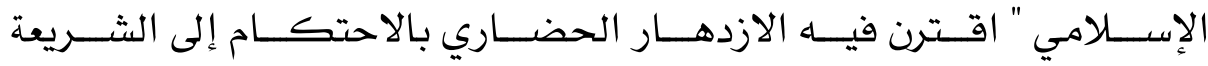

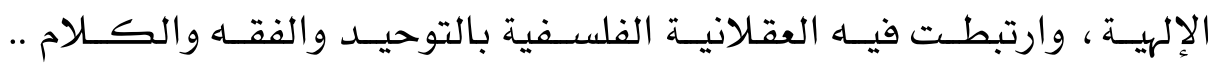

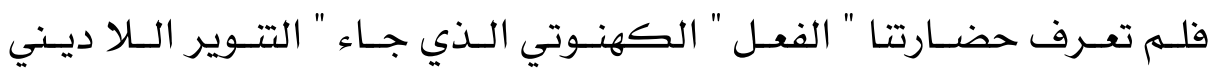

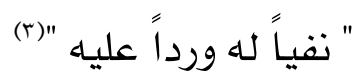

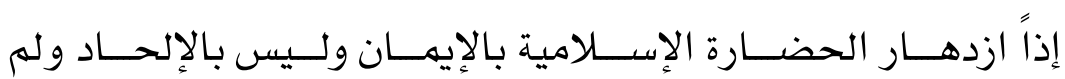

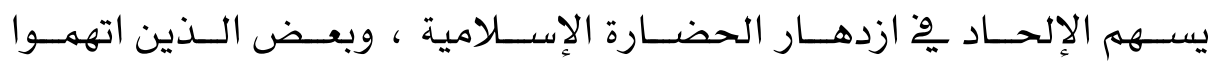

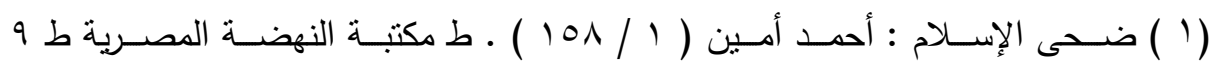

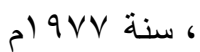

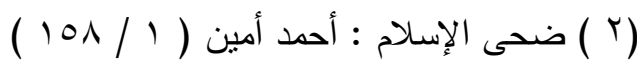

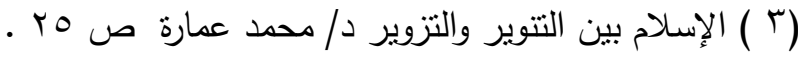




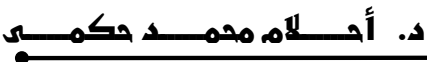

\section{التنوير الغريهي والتنيويجي الإسلامي درأستمقارئي}

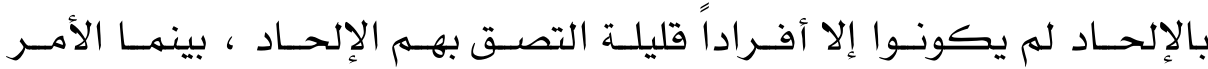

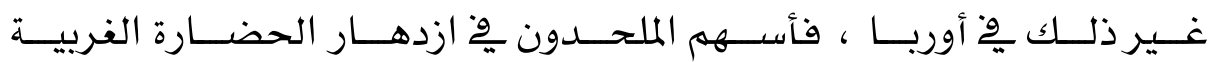
وسهــي عصـرهم بعصــر الإلحــاد ، وهـــو عصــر النهضــة عنــدهم القــائم

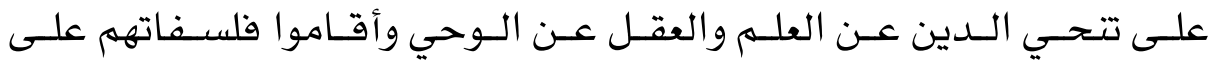

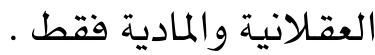

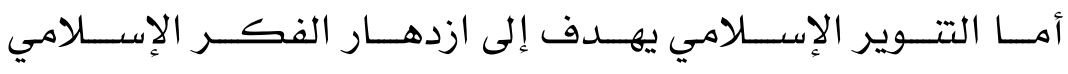

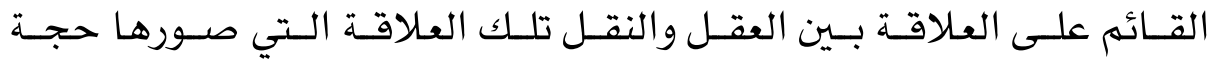

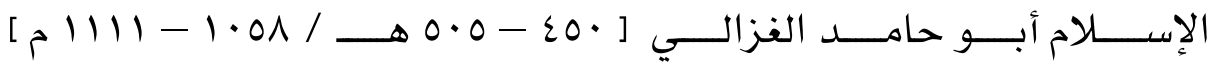

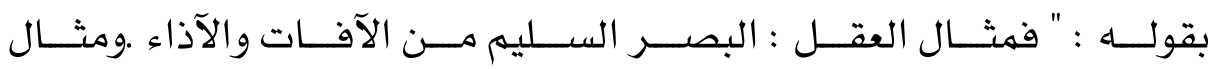

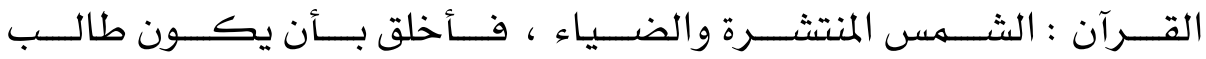

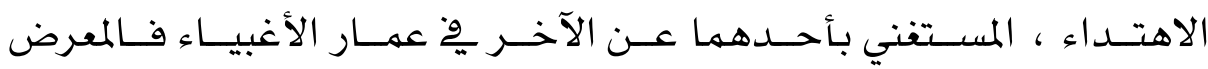

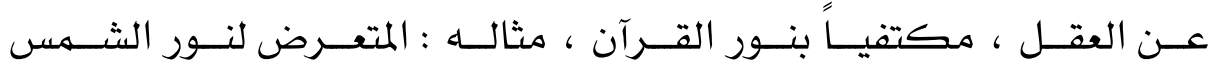

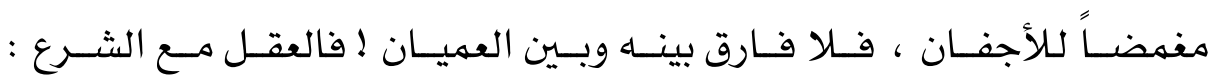
نور على نور "(1)

هــذا هــو الإســـلام الـــي يضــيء فيـهـ النقـل ليسـير العقـل بنـور

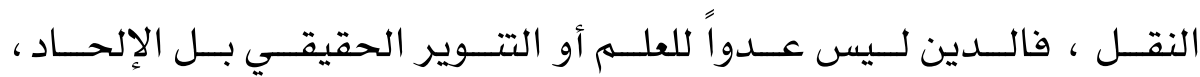

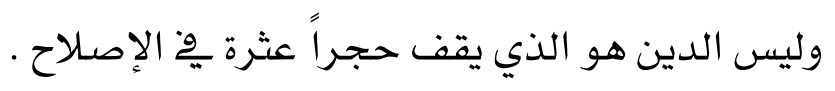

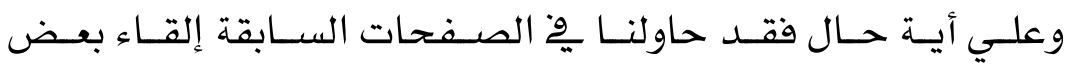
الضوء علي مصطلح التتوير ودلالته وِّ الفكرين الغربي والإسـلامي، ولئ

( ( ) راجـع الاقتصـاد فـي الاعتقـاد : الإمــام الغزالـي ص ^ ، مكتبـة الجنـدي ، بـدون تاريخ 


\section{وقد تبين لنا من خلالها أن هناك نوعين من التنوير:}

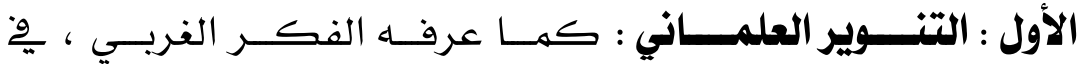

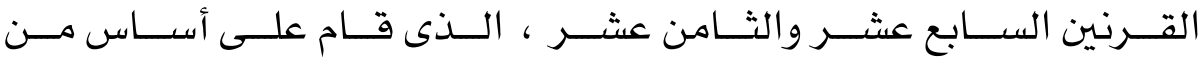

تقديس العقل والطبيعة ، والفصل بين الدين والحياة .

الثـــاني : التنــــوير الإســـلامي : كهــا حــددت معالمـهـ المصــادر

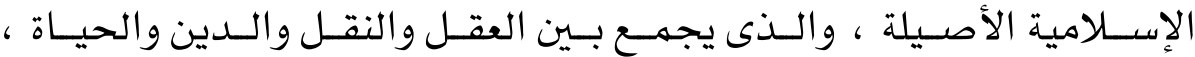

ولا يقيم قطيعة معرفية بين هذه الأطراف. وبعد ...

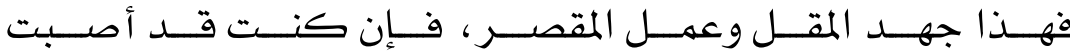

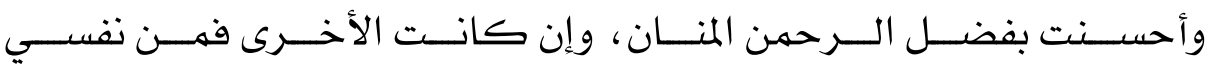

والشيطان، وأسأل الله تعالى العفو والغفران.

وصلي الله على سيدنا محمد وعلى آله وصحبه وسلهم. 


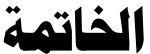

وتشتهمل على أهمر ما تهخض عنـه البحثث من نتائج.

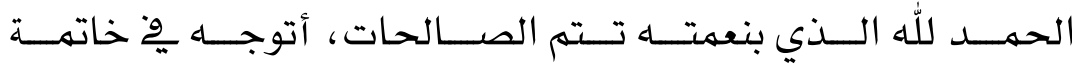

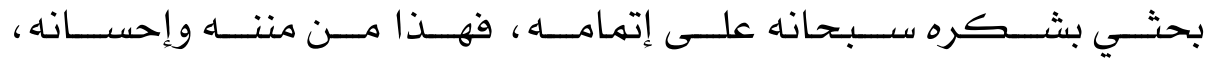

وأخلص إلى تلخيص أهم نتائج البحث فيما يأتي:

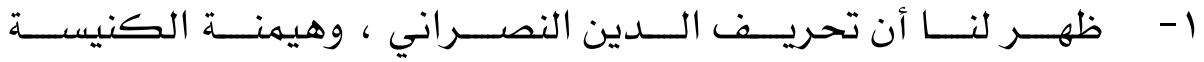

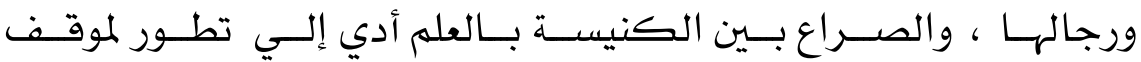

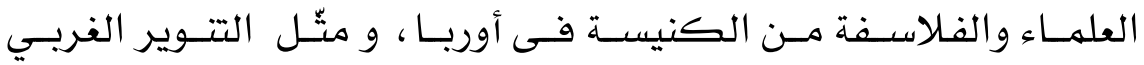

الـذي يعتمــد علـى تهـيــد العقـل والفصـل بــين الـدين والحيــاة -

العلمانية - نوع من هذا التطور.

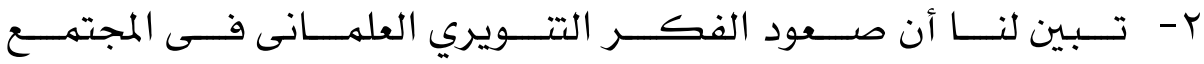

الإســلامي ، كـان فـى ظلـل الاسـتعمار الغربـى وحمايتــه لحركــات

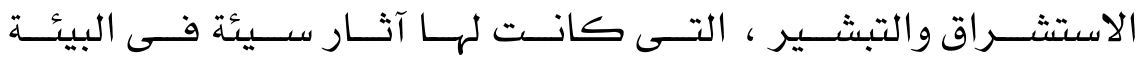

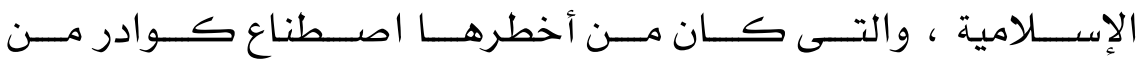

العلهـانيـن العـرب المســتفربين الـذين تخرجــوا فـى الجامعـات الغربيـة

التــى ابتعثــوا إليهـــا ، أو فــى مــــارس الإرســـاليات التبشــيرية فـى

العــالم الإســلامى ، وكــان أبــرز النمــاذج لهـذه الخطــة : نصـــارى

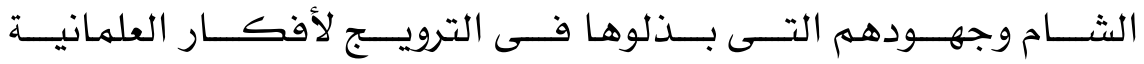

\section{والقومية.}

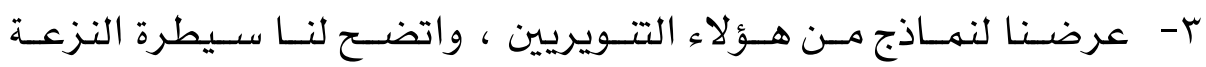
الماديــة علــى أفكـــارهـم حـــول القــرآن والــوحى والنبــوة والثـــريعة 
والعقيـــدة ، وســـعيهم إلى تقنـــيـين فكــــرة العلمانيـــة وتســــويغهم

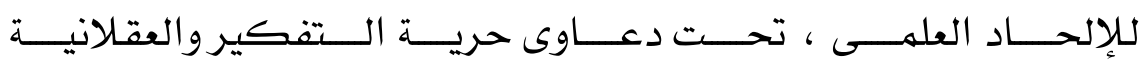

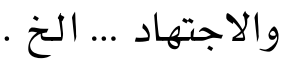

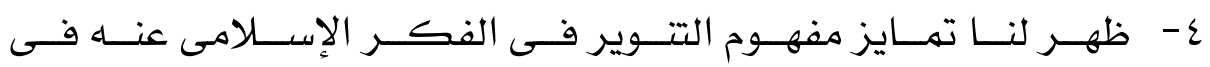

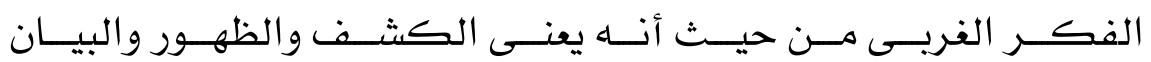

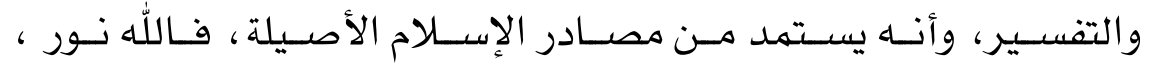
والرسـول نور والقرآن نور والإسـلام كله نور وتتوير .

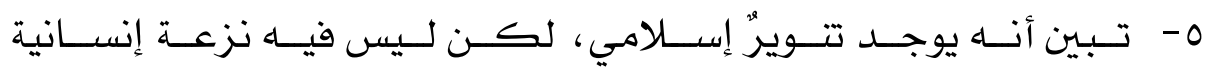

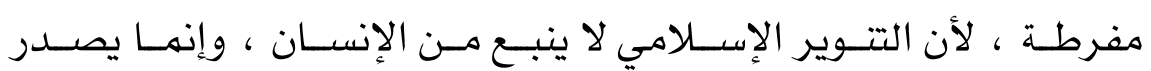

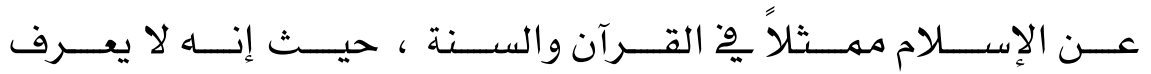

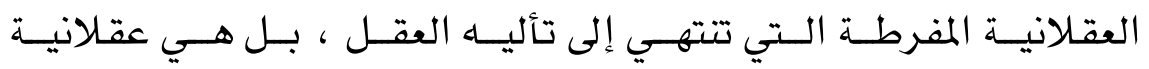

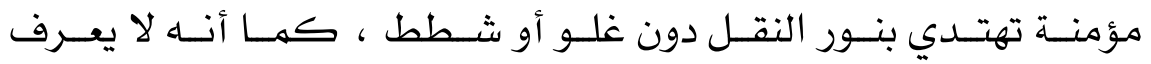

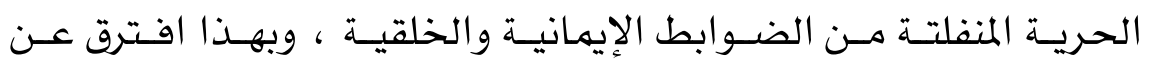

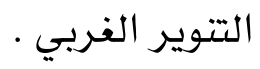




\section{ثبت بأهم المسادر والمراجع}

اولاً: القرآن الكريه.

ثانياً: السنة النبوية المطهرة.

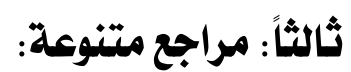

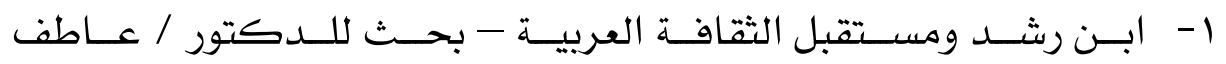

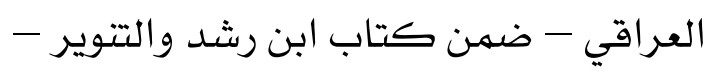

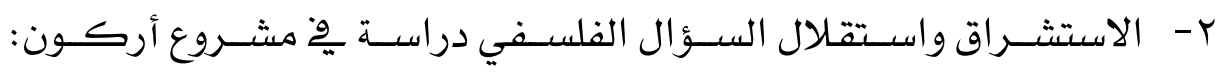

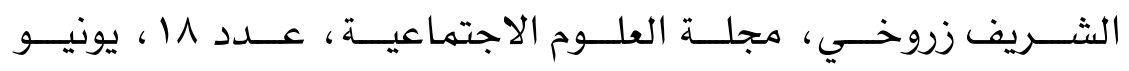

$$
\text { . } r \cdot 1 \varepsilon
$$

ب- الإســلام بـين التــوير والتزويــر د / محهـــ عهــارة دار الشــروق الأولـي

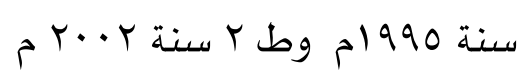

ع - الإســلاموالتــوير د / محمــود حمــــي زقـزوق، مجلــة منــبر الإســلام

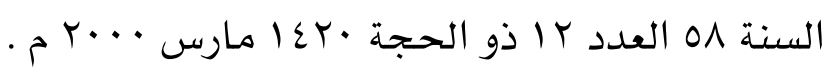

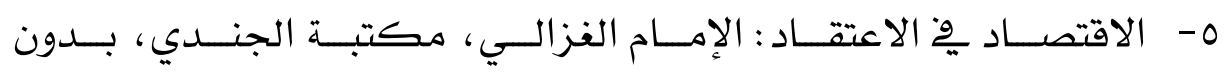

$$
\text { تاريخ }
$$

7- تاريخ الفلسفة، د / محمد عزيز نظمي سـالم مؤسسـة شـباب الجامعـة ط

$$
\text { أولى بدون تاريخ }
$$

V- التأويـل الحـــاثي للـتراث: التقنيـات والاسـتمدادات، إبـراهيم بـن عمـر

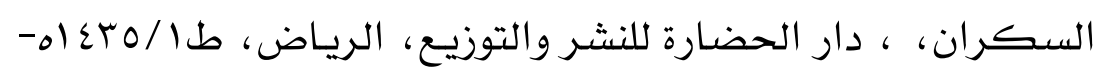

$$
\hat{r}^{r \cdot 1 \varepsilon}
$$




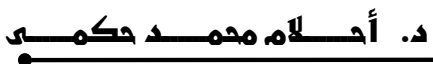

\section{التنوير الغريهي والتنتويجي الإسلاميي

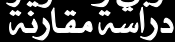

1- تراثــا التــويري وضــرورة التجديـــ : / / حسـن حنفـي، مجلـة الـوعي

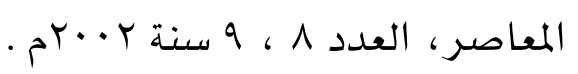

9- التقـدم والإصـلاح بـالتوير الغريسي؟ أم بالتجديـد الإسـلامي: د / محمـــ

$$
\text { عمارة، دار الشروق الأولي سنة } 1990
$$

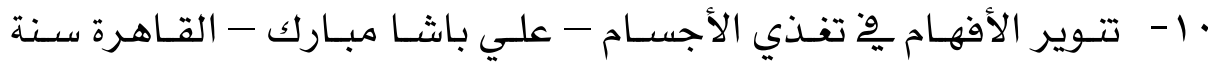

$$
\text { (r) }
$$

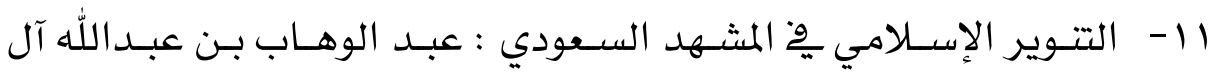

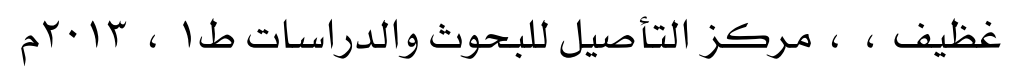

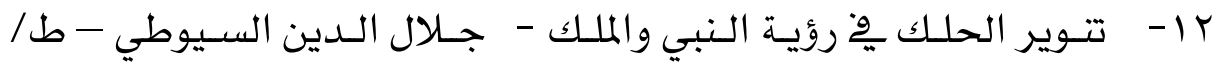

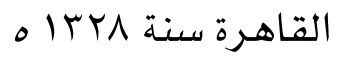

rا- ت تــوير الحوالـك شــرح موطـأ الإمـام مـالـك للسـيوطى ط/القـاهرة ســـة

$$
\text { ، 1 l tror }
$$

ع ا- التتوير الزائف : د / جلال أمين دار المعارف سلسلة اقرأ رقم •ع .

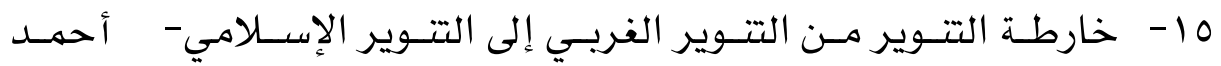

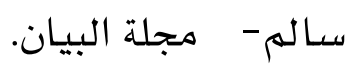

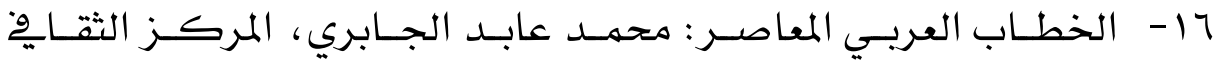

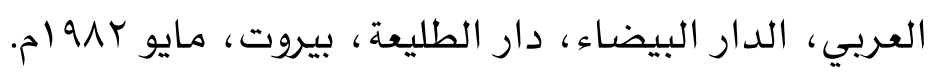

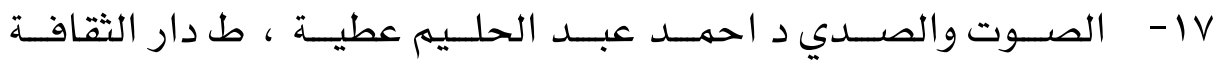
للنشر والتوزيع مصر طا سنة • 199 ام. 


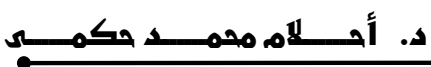

\section{التنوير الغريجي والتينوير الأسلامي \\ دراستيمقارئي}

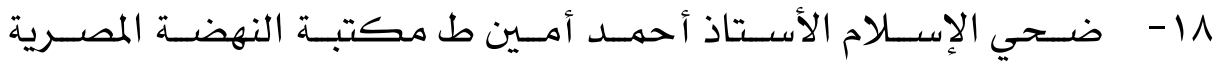

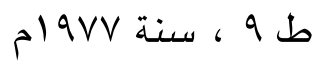

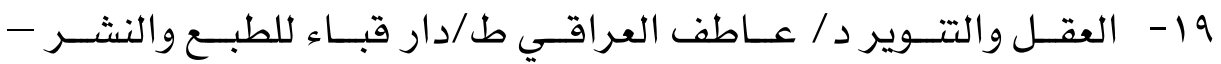

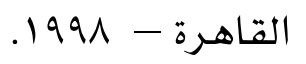

•r- العلمانيـة الجزئيـة والعلمانيـة الثــاملة، د / عبــــ الوهــاب المسـيري،

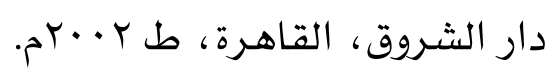

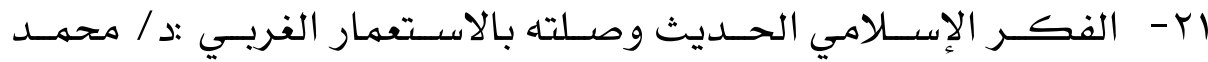

البهي ط / مكتبة وهبة - الثالثة عشرة سنة 1997 .

ب ب- الفككـر الإســلامي المعاصــر مقوماتـهـ ومعالمــهـه ، رســالة دكتـوراه

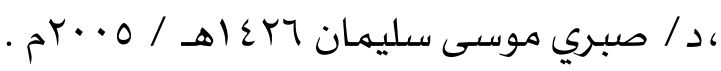

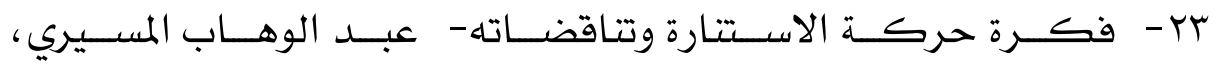

$$
\text { طبعة نهضة مصر، الطبعة الأولي } 991 \text { ام. }
$$

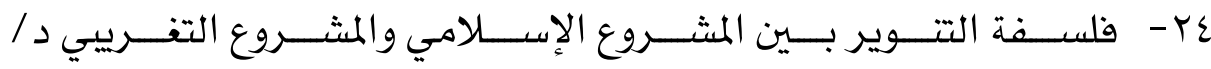
محمد السيد الجليند ، $199 V$ م.م.

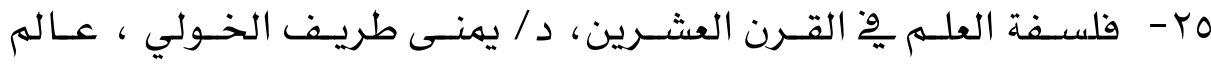

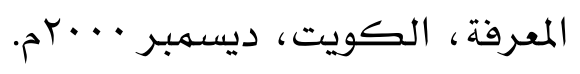

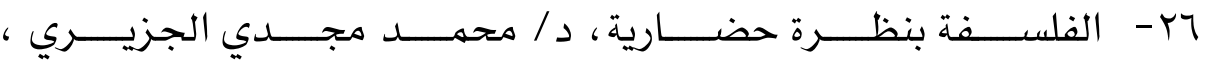

$$
\text { بروفيشنال للإعلام والنشر، القاهرة ( طا عهله ام ). }
$$

rV

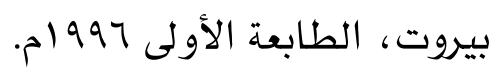




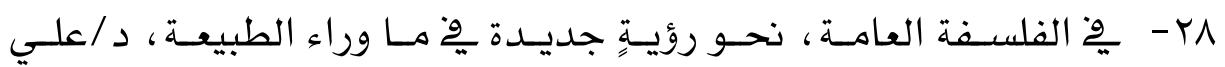
أبو ملحهم ، دار العلوم العربية، بيروت، طا 991 ام.

وب - القــاموس المحـيط - الفـيروز آبـادى ط / مصــطفي البـابي الحلـبـي - الثانية لسنة 190r م

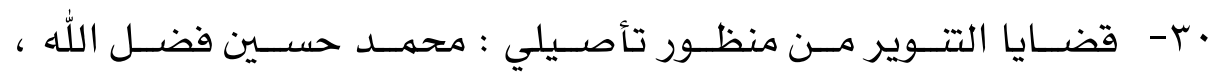

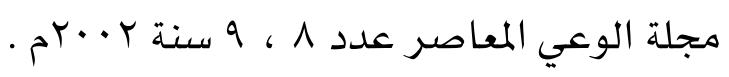

اس- هــا هــو التـاريخخ كــارل إدوارد ترجمــة : مــاهـر كيـالي، المؤسســة

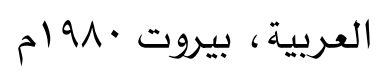

ץ r- مجلــة الــوعي المعاصــر ، مقــال بعنـــوان: الواحديــة المســتبـدة وثــورة

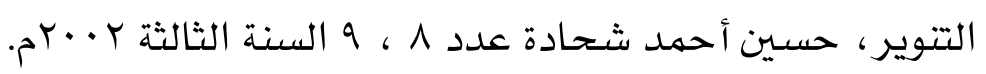

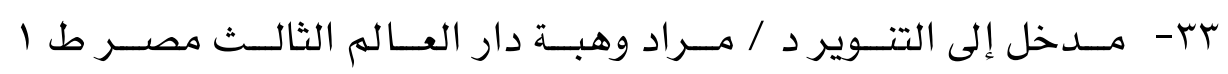
سنة

ع ب- مــدخل إلـي التــوير : د / مــراد وهبـة : ، مجلـة اليقظـة العربيـة عـدد مارس · 199

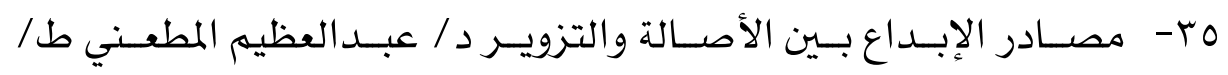
مكتبة وهبة الأولي سنة ألة 1999 ام .

حب- المعتجـهم الفلســفي: جميـل صـليبا ط دار الكتــاب اللبنــاني بـيروت م $191 \mathrm{r}$

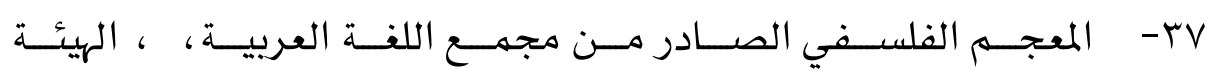

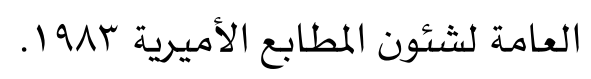




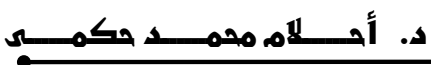

\section{التنوير الغريجي والتينوير الأسلامي \\ دراستيمقارئي}

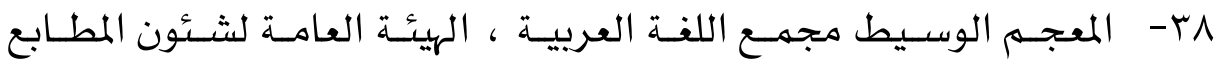

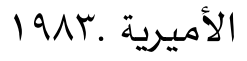

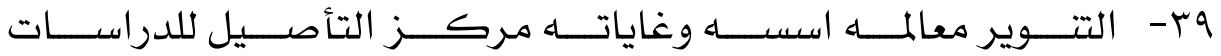

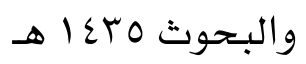

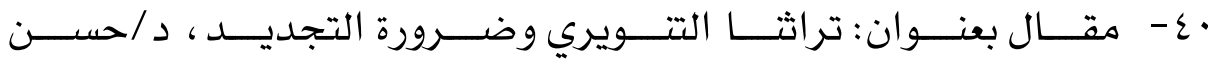

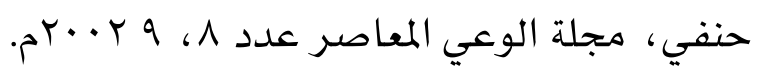

اع- مقــال تطــور الفكــر الــديني الفربـي " الإنســان والله " د / حســن

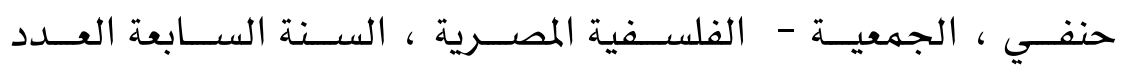

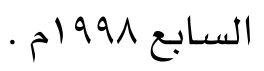

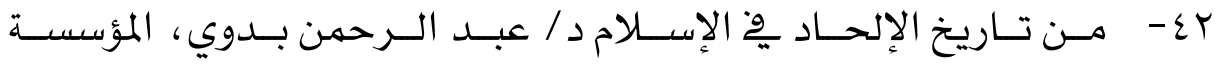

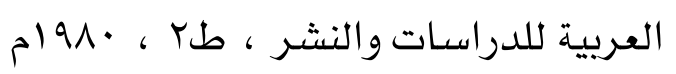

rع - ملاك الحقيقة المطلقة: مـراد وهبة مكتبة الأسـرة عام 1999 م

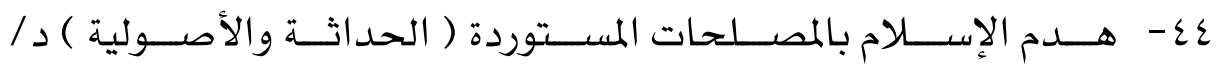

$$
\text { زينب عبد العزيز-دار الأنصار لسنة } 1997 \text { م. }
$$

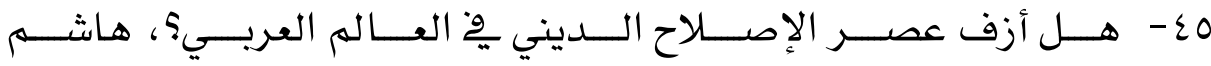

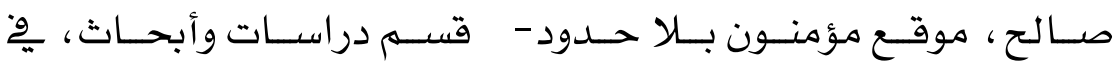

$$
\text { r. } r \cdot 11 / 1
$$

7عـ- اليقظــة الفلسـفية المفربيــة ودرء آفــة التقليــد د طــهـ عبــد الـرحمن

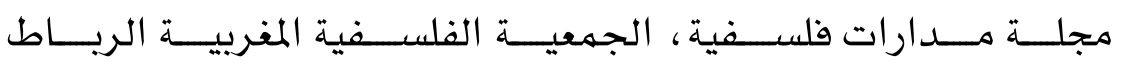

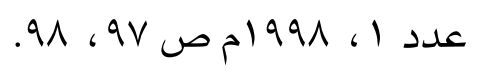


فهرس المرضوعات

\begin{tabular}{|c|c|}
\hline الصفهة & الموضفـــع \\
\hline $1 \varepsilon 9 V$ & الاقدهة: وتشتمل على أهميت البحث، وأسباب اختياره، \\
\hline $10 \cdot r$ & الفصل الأول: التنوير الغربي ومقوماته \\
\hline $10 . r$ & الهبــ 1الآول: معني التنوير الغربي ونشأته \\
\hline 1014 & المبــث الثانـي : مقومات التنوير الغربي \\
\hline lore & 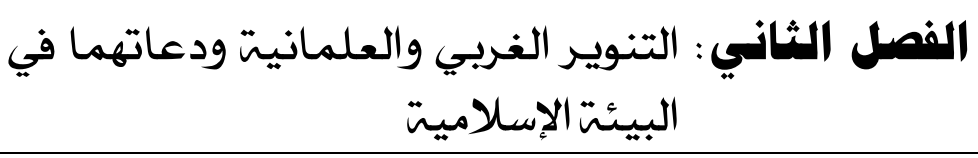 \\
\hline loro & المبــث الآول: العلاقت بين التنويـروالعلمانيت \\
\hline lore & المبــث الثانـي : دعاة التنوير الغربي في البيئت الإسلاميت \\
\hline 1007 & الفصل الثالث: التنوير الإسلامي ومقوماته \\
\hline $100 \mathrm{~V}$ & المبــث 1آول: مفهوم التنوير الإسلامي ومصدره \\
\hline $107 \varepsilon$ & المبــذ الثانـي: مقومات التنوير الإسلامي \\
\hline 1071 & الخاتمة: وتشتمل على أهم ما تمخض عنه البحث من \\
\hline $10 \mathrm{VI}$ & بأهم الهـادر والمراجع \\
\hline lov7 & 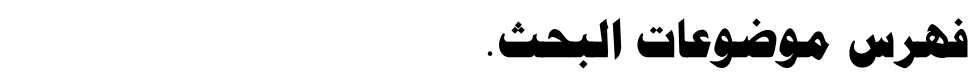 \\
\hline
\end{tabular}

